ISH-- $-252-1 \%$

DES2 $016 \% 17$

\title{
Environmental Analysis of the Bayo Canyon (TA-10) Site, Los Alamos, New Mexico
}

Roger W. Ferenbaugh

Thomas E. Buhl

Alan K. Stoker

Wayne R. Hansen

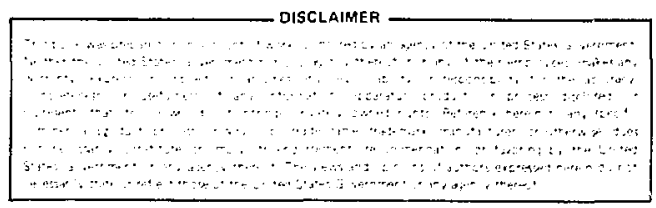

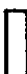

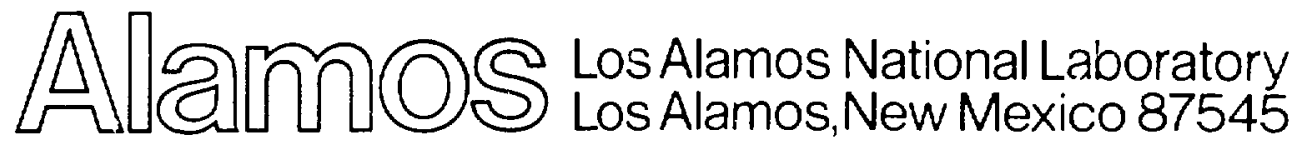




\section{CONTENTS}

ABSTRACT

1.0 INTRODUCTION AND BACKGROUND

1.1 The FUSRAP Program

1.2 Preferred Alternative

2.0 THE BAYO CANYON SITE

2.1 Summary History and Description of Site

2.1.1 Description of Site

2.1.2 History of Site

2.2 Need for Action

2.2.1 Radiological Risk

2.2.1.1 Method of Estimating Risk

2.2.1.2 Results of Dose Calculations

2.2.1.3 Health Risks from Residual Bayo Canyon Cont amination

2.2.2 Criteria upon Which Cleanup Action is Based

2.3 Other Agencies Involved in Implementation of the Proposed Action

3.0 ALTERNATIVES

3.1 Alternative I (Preferred Alternative)--Minimal Action

3.2 Alternative II--Decontamination and Restoration with Disposal

3.3 Alternative III--No Action

4.0 AFFECTED ENVIRONMENT 21

4.1 Land Use 21

4.1.1 Bayo Canyon 21

4.1.2 TA-54 (Radioactive Solid Waste Disposal Site) 21

4.1.3 Transportation Route 21

4.1.4 Borrow Area 23

4.2 Socioeconomics 23

4.2.1 Demography 23

4.2.2 Economy 23

4.2.3 Institutional 24

4.2.4 Community Services 25

4.2.5 Archaeology 25

4.3 Soil and Geology 26

4.4 Climatology 28

4.4.1 General C! imate 28

4.4.2 Air Quality 28

4.5 Hydrology and Water Quality 29 
4.6 Biotic Environmental Factors $\quad 29$

4.6.1 General Ecology 29

$\begin{array}{lll}4.6 .2 & \text { Plants } & 29\end{array}$

4.6.2.1 Characterization 29

4.6.2.2 Rare and Endangered Species 30

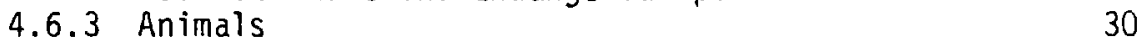

4.6.3.1 Characterization 30

4.6.3.2 Rare and Endangered Species 32

4.7 Summary of Radiological Conditions 32

4.7.1 Background Radiation and Radioactivity 32

4.7.2 Surface Soil Conditions 35

4.7.2.1 Probability of Surface Contamination
Exceeding the Working Criteria

4.7.2.2 Existing Conditions 38

4.7.3 Subsurface Soil Conditions (Below $30 \mathrm{~cm}$ ) 44

5.0 ENVIRONMENTAL CONSEQUENCES 44

5.1 Minimal Action Alternative (Alternative I)--Preferred
Alternative

5.1.1 Radiological Consequences 44

5.1.2 Ecological Consequences 44

5.1.3 Land Use Impacts 44

5.1.4 Socioeconomic Effects $\quad 45$

5.1.5 Risk to Individual Health and Safety 45

5.2 Decontamination and Restoration Alternative
(Alternative II)

$\begin{array}{ll}5.2 .1 \text { Radiological Consequences } & 45\end{array}$

5.2.2 Ecological Consequences 45

5.2.3 Land Use Impacts 47

5.2.4 Socioeconomic Effects 47

5.2.5 Risk to Individual Health and Safety 48

5.3 No-Action Alternative (Alternative III) 50

5.3.1 Radiological Consequences $\quad 50$

5.3.2 Ecological Consequences 50

5.3.3 Land Use Impacts 50

5.3.4 Socioeconomic Effects 50

5.3.5 Risk to Individual Health and Safety 50

REFERENCES 50

APPENDIX A--BAYO CANYON SOIL FERTILITY DATA

APPENDIX B--DOSE CALCULATION PROCEDURES

1.0 DERIVATION OF SOIL LIMITS

2.0 CALCULATION OF RADIATION DOSES

2.1 Inhalation of Contaminated Soil (0- to $5-\mathrm{cm}$ soil layer) 65

2.2 Ingestion of Homegrown Produce (0- to $30-\mathrm{cm}$ soil layer) 65

2.3 Doses to Construction and Cleanup Workers 66

2.4 Doses Resulting from Transportation of Bayo Soil to TA-54 67 
2.4.1 Dose to the Driver of a Truck Hauling Contaminated Soil 2.4.1.1 Beta Dose 67

2.4.1.2 Bremsstrahlung Dose $\quad 67$

2.4.1.3 Inhalation dose 70

2.4.2 Doses Resulting from an Accidental Spill of
Contaminated Soil

$\begin{array}{ll}\text { REFERENCES } & 71\end{array}$

APPENDIX C--PLANTS OF PUEBLO CANYON 73

APPENDIX D--ANIMALS IN LOS ALAMOS ENVIRONS 76

FIGURES

1. Location of former Bayo Site

2. Physiographic setting of Bayo Canyon

3. Layout of former Bayo Site

4. Waste handling facilities at Bayo Canyon

5. Location of TA-54 and transporation route from Bayo Canyon

6. Surface debris from Bayo Canyon

7. Confidence boundary isopleths for gross $\beta$ concentrations

8. Confidence boundary isopleths for gross a concentrations 40

TABLES

I. SIGNIFICANT STRUCTURES DECOMMISSIONED AT BAYO SITE 10

II. RISK COMPARISON DATA 12

III. DOSE EVALUATION FOR BAYO CANYON 15

IV. ABOVE-BACKGROUND SOIL CONCENTRATIONS 15

V. ALTERNATIVES, ASSOCIATED ACTIONS, AND ADVANTAGES AND
DISADVANTAGES

VI. COMMON HERBS AND SHRUBS OF THE BAYO CANYON AREA 31

VII. PLANTS PROTECTED BY NEW MEXICO STATE LAW THAT MIGHT BE FOUND IN BAYO CANYON

VIII. MAMMALS TRAPPED OR SIGHTED IN ACID-PUEBLO CANYON 33

IX. STATE-LISTED ENDANGERED ANIMAL SPECIES FOR NORTHCENTRAL NEW MEXICO

$X$. CONCENTRTIONS OF ${ }^{90} \mathrm{Sr}$ AND URANIUM IN SOIL

$X I . \quad$ COMPARISON OF ${ }^{90} \mathrm{~S} r$ IN SURFACE AIR

34

XII. COMPARISON OF TOTAL URANIUM IN SURFACE AIR

41

XIII. EXTERNAL EXPOSURE

42

XIV. DOSE EVALUATION FOR BAYO CANYON CLEANUP

43

49 
ENVIRONMENTAL ANALYSIS OF THE BAYO CANYON (TA-10) SITE, LOS ALAMOS, NEW MEXICO

\section{by}

Roger W. Ferenbaugh, Thomas F. Buhl, $A l$ an K. Stoker, and Wayne R. Hansen

\section{ABSTRACT}

The radiological survey of the old TA-10 site in Bayo Canyon found low levels of surface contamination in the vicinity of the firing sites and subsurface contamination in the old waste disposal area. The three alternatives proposed for the site are (1) to take no action, (2) to restrict usage of the area of subsurface contamination to activities that cause no subsurface disturbance (minimal action), and (3) to remove the subsurface contamination to levels below the working criteria. Dose calculations indicate that doses from surface contamination for recreational users of the canyon, permanent residents, and construction workers and doses for workers involved in excavation of contaminated soil under the clean up alternative are only small percentages of applicable guidelines. No environmental impacts are associated with either the no-action or minimal action alternatives. The impact associated with the cleanup alternative is small, especially considering that the area already has been affected by the origina? TA-10 decommissioning action, but nevertheless, the preferred alternative is the minimal action alternative, where 0.6 hectare of 1 and is restricted to surface activities. This leaves the rest of the canyon available for development with up to 400 homes. The restricted area $c$ an be used for a park, tennis courts, etc., and the ${ }^{90} \mathrm{Sr}$ activity will decay to levels permitting unrestricted usage in about $160 \mathrm{yr}$.

\subsection{INTRODUCTION AND BACKGROUND ${ }^{1}$}

\subsection{The FUSRAP Program}

In 1976, the Energy Research and Development Administration (ERDA) identified the Bayo Canyon Site as one of the locations to be reevaluated as part of the Formerly Utilized Sites Remedial Action Program (FUSRAP). The sites identified in the FUSRAP program were to be resurveyed for radiological contamination using moderri instrumentation and analytical methods. The resurveys are the bases for deternining whether any further remedial action is necessary. The Bayo Canyon resurvey was performed by the Los Al amos Scientific Laboratory under contract to ERDA and, subsequently, to the DOE.

The results of the survey ${ }^{1}$ indicated low-level surface $(<1-m)$ contamination with ${ }^{90} \mathrm{Sr}$ and uranium. Subsurface $(6-$ to $8-\mathrm{m})$ contamination was found in the vicinity of the old waste disposal area. Because of the residual contamination located by the resurvey, a set of 
alternatives for remedial action for Bayo Canyon has been identified. An engineering evaluation of the proposed alternatives has been prepared by Ford, Bacon \& Davis Utah. ${ }^{2}$ This document describes the envirorimental consequences associated with the proposed alternatives.

\subsection{Preferred Alternative}

The range of alternatives being considered for Bayo Canyon includes no action, minimal action, and decontamination with restoration and disposal. The minimal action alternative requires demarcation and control of the area of subsurface contamination to prevent disturbance. Decontamination with restoration and disposal involves exhumation and disposal of the subsurface contamination, followed by rehabilitation of the disturbed area.

The most reasonable alternative for Bayo Canyon appears to be the minimal action alternative. This alternative requires control and surveil'ance of the 0.6-hectare plot of 1 and encompassing the former solid and liquid waste disposal areas. This action would preclude any subsurface disturbance that could intrude into the region of subsur face contamination. The remainder of the canyon would be available for unrestricted use. This alternative is discussed in detail in Section 3.1 .

The basis for selecting this alternative is that the additional impact and cost of removal of the subsurface contamination provide little additional benefit. Under the minimal action alternative, there is virtually no environmental impact, the cost is low, and only 0.6 hectare is unavailable to the County for residential development or for other uses. The New Mexico State Environmental Improvement Division (EID) concurs that the contaminated soil presents no radiological hazard if kept at depth. ${ }^{3}$ The environmental impact and cost of exhuming the subsurface contamination provide oniy an additional $0.6 \mathrm{hec}-$ tare of land for development or other use.

\subsection{THE BAYO CANYON SITE}

\subsection{Suminary History and Description of Site}

2.1.1 Description of Site. Bayo Canyon is adjacent to the townsite of Los Alamos in northcentral New Mexico, about $100 \mathrm{~km}$ NNE of Albuquerque and $40 \mathrm{~km} \mathrm{NW}$ of Sarita Fe by air (Fig. 1). Bayo Canyon is une of many canyons cut into the Pajarito Plateau (Fig. 2). The Technical Area $10(T A-10)$ site in Bayo Canyon is located about $5 \mathrm{~km}$ east of the community of Los Al amos and $8 \mathrm{~km}$ northwest of the community of White Rock at T20N, R6E, Sections 12 and 13. The area encompassing the site is legally described as the Bayo Canyon Parcel, as shown on the Walsh Survey Plat thereof, which survey plat was filed for record with the Clerk of Los Alamos County, New Mexico, on August 16, 1965, Plat Book \& Page 59, Document No. 4552. 


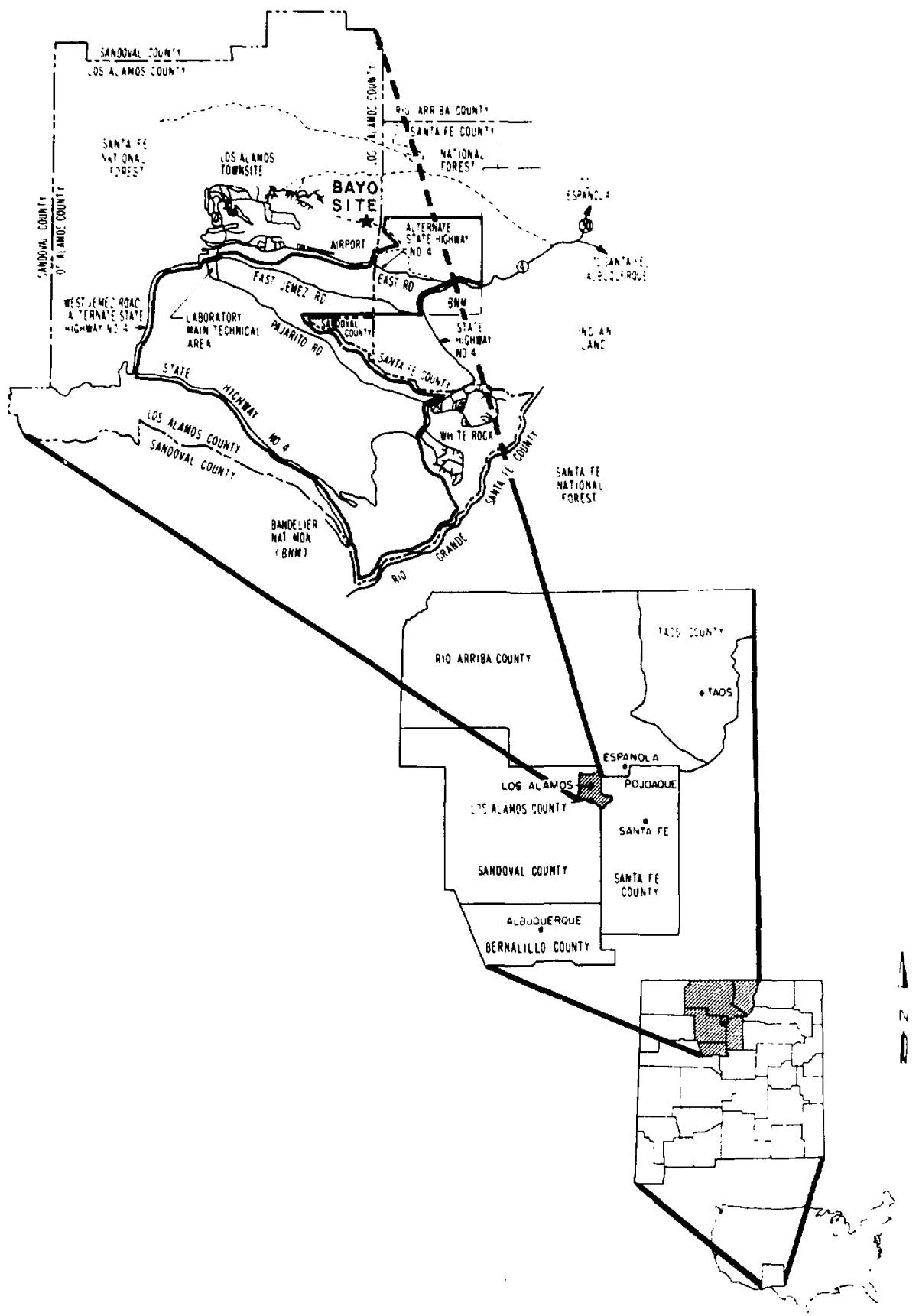

Fig. 1. Location of former Bayo Site. 


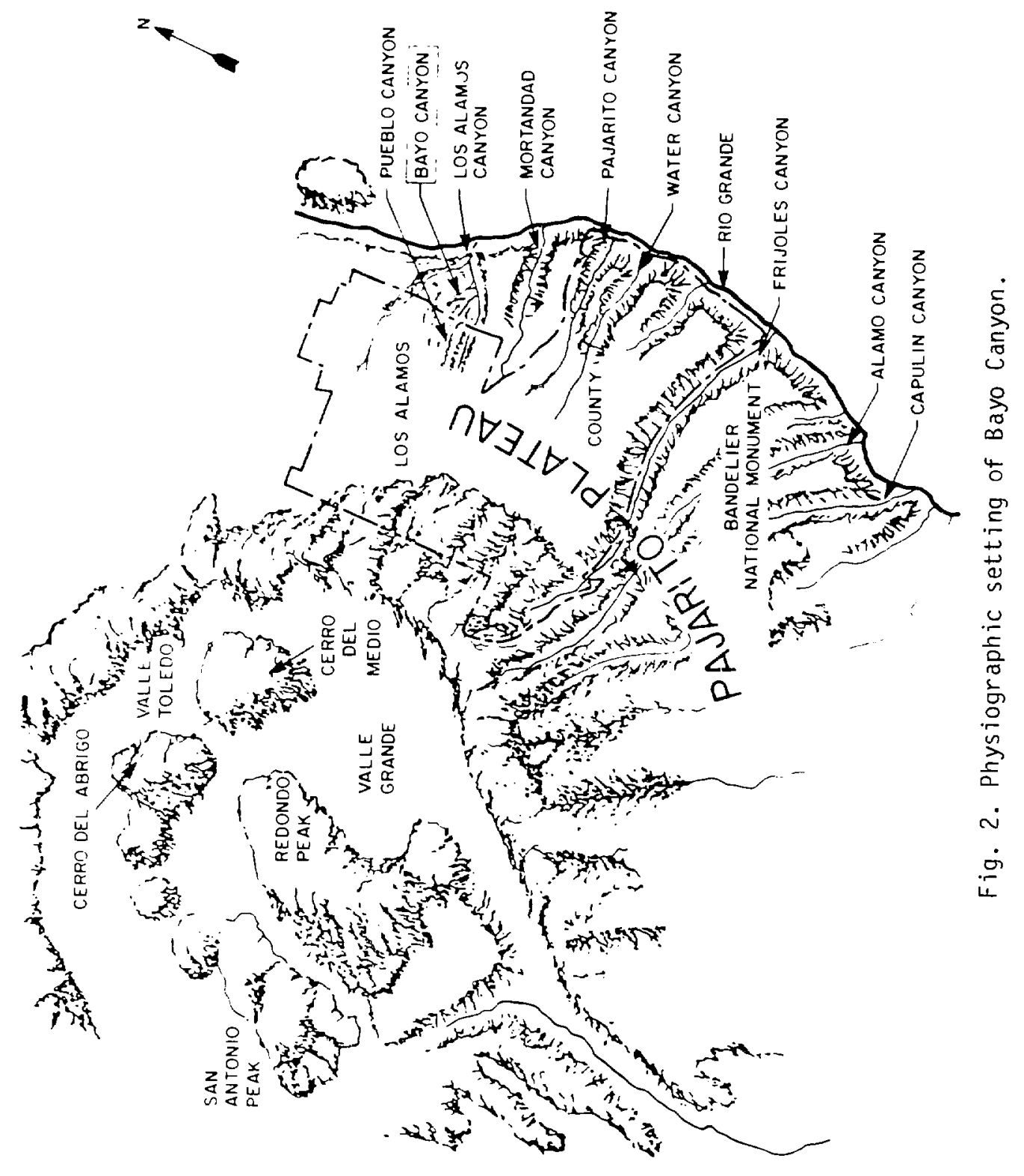


The facilities associated with the former test site, TA-10, were built in the bottom of Bayo Lanyon, where now only a few remnants remain. Bayo Canyon trends generally in an east-west direction. The north boundary of the site is considered to be on a generally east-west 1 ine along the top of Otowi Mesa (Fig. 3). The south boundary, similarly, is an east-west line along the top of Kwayle Mesa. The east boundary is a north-south line approxinately $150 \mathrm{~m}$ east of the former radiochemistry laboratory, and the west boundary lies approximately $300 \mathrm{~m}$ to the west of the former firing site area. Access to the site is from New Mexico State Road 4 onto a dirt road leading west across DOE property into Pueblo Canyon and then into Bayo Canyon.

2.1.2 History of Site. ${ }^{1}$ Facilities for conducting experiments with high explosives were constructed in Bayo Canyon in 1943 for Project $Y$ of the Manhattan Engineer District (MEO). The facilities were used until 1961 for experiments relating to the development of nuclear weapons at the Los Alamos Scientific Laboratory, operated by the University of California under contract to the Atomic Energy Commission (AEC). In 1963, the Bayo Site, alternatively referred to as TA-10, was decontaminated to detection limits of available instrumentation and demolished. The land was turned over to Los Alamos County by quitclaim deed in 1967.

The principal structures comprising TA-10 (Fig. 3) included a radiochemistry laboratory (TA-10-1), two assembly buildings (TA-10-10 and $T A-10-12)$, an inspection building (TA-10-8), a personnel building (TA-10-21), and structures at two detonation control complexes, particularly the control buildings (TA-10-13 and TA-10-15) and adjacent firing pads. Ancillary facilities included sanitary and radioactive liquid waste sewage lines, manholes, septic tanks and seepage pits, and solid radioactive waste disposal pits.

Radioactivity was released into the environment in Bayo Canyon primarily by (1) the explosive shots, which contained radioactive materials, and by (2) the disposal of radioactive wastes from radiochemistry operations. Secondary sources included airborne exhausts from laboratory hoods, accidental spills, and redistribution during decommissioning operations.

The explosive test assemblies usually included components made from natural or depleted uranium and a radiation source for blast diagnostics. The sources contained several hundred to several thousand curies of $140 \mathrm{La}$ (half-7ife $40.2 \mathrm{~h}$ ) and a small portion of $90 \mathrm{Sr}$ (h:ilflife $28.1 \mathrm{yr})$. The sources were prepared in the radiochemistry lais (TA-10-1) at Bayo Site by radiochemically separating the 140 La from a solution containing the radioactive parent ${ }^{140} \mathrm{Ba}$ (half-life 12.8 days), the stable daughter $140 \mathrm{Ce}$, and other impurities, including ${ }^{90} \mathrm{Sr}$. The separated ${ }^{140} \mathrm{La}$ and an unavoidable proportion of ${ }^{90} \mathrm{Sr}$ were precipitated onto a filter medium and encased in foil to form a source. (separation, precipitation, and encapsuiation were performed at IA-10-1 between 1944 and 1950. Subsequently, only the precipitation 


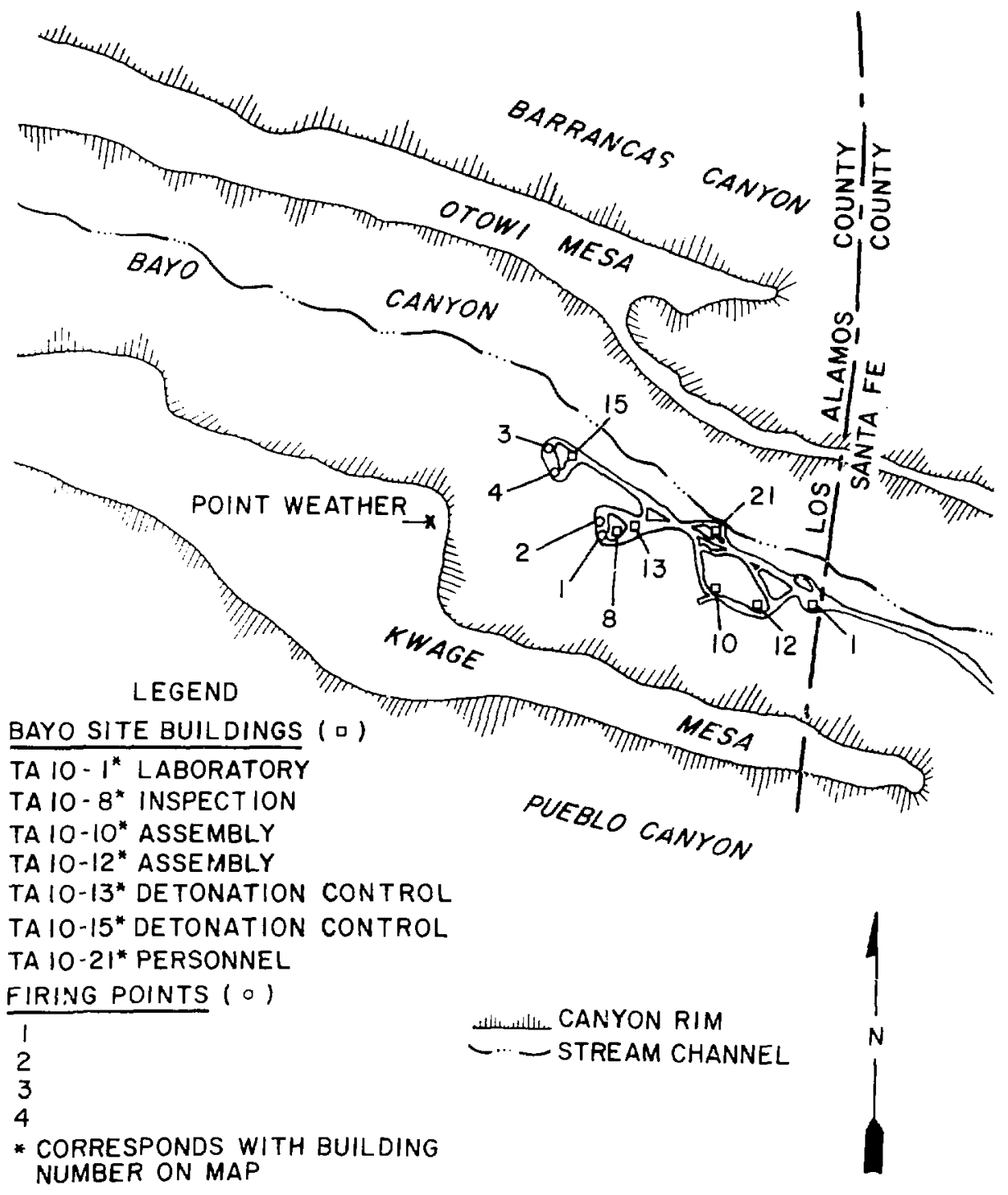

Fig. 3. Layout of former Bayo Site. 
and encapsulation operations were performed there, and the radiochemical separations were done at another laboratory sti?l on DOE land.) Other components of test devices were assembled in buildings TA-10-13 and TA-10-15, inspected in building TA-10-8, and placed on one of the shot pads. Once the source was inserted, the experiment was remotely detonated from one of the control buildings, TA-10-13 or TA$10-15$.

The explosive detonation resulted in the dispersion of radioactive materials (uranium, ${ }^{140} \mathrm{La}$, and ${ }^{90} \mathrm{Sr}$ ), as well as nonradioactive materials (copper, lead, aluminum, etc.), in the form of aerosols and solid debris. Depending on wind conditions, aurosols were dispersed to varying degrees both within Bayo Canyon and beyond the adjacent mesas. Standard procedures required a southwesterly wind at the time of detonation; however, routine postshot surveys out to about 5 miles did at times find 140 La contamination in the vicinity of State Road 4 and on Otowi and Kwage Mesas. On one occasion, an aircraft was able to track airborne $140 \mathrm{La}$ activity eastward across the Rio Grande Valley. Solid debris, including fragments of uranium and other metal components, was scattered around the firing points, largely within 90 to $125 \mathrm{~m}$. Some large fragments were found 300 to 600 $m$ away. Some radioactivity was dispersed around the firing pads by water from postshot cleanup. Radiation levels around the pads were frequently in the range of a few tenths to a few roentgens per hour.

The disposal of liquid and solid radioactive wastes resulted in the deposition of radioactivity below the surface. Radioactive liquid wastes from the radiochemistry building (TA-10-1) were collected in so-called acid waste lines and subsequently flowed to holding tanks, pits, and a leaching field to the north. Liquids placed or flowing into the pits drained through an outlet pipe at the bottom into the earth. Liquid wastes from the storage tanks were periodically discharged directly into the stream channel. The basic components of the waste disposal system are depicted in Fig. 4. Sanitary sewage lines, septic tanks, the TA-10-1 outfall line, and the TA-10-21 disposal pit, also shown in Fig. 4, may have received some contaminated liquid waste. Solid radioactive wastes were disposed into two of the six pits located as showri in Fig. 4.

Other smaller quantities of radioactivity may have been released with the unfiltered exhausts from fume hoods used for the routine radiochemical processing carried out in building TA-10-7. This resulted in the accidental dispersal of some a activity, evidenced by contamination on the roof of the building. Some cleanup was undertaken, and a activity remaining on the roof was stabilized by mastic.

Bayo Site was decommissioned starting in 1960 with the demolition or burning of several buildings. In 1963, the rest of the buildinos were demolished or burned, the sewer systems removed, the contaminated waste pits excavated, and surface debris picked up out to a radius of about $760 \mathrm{~m}$ from the detonation control builuings. All debris was removed for disposa? in the contaminated waste burial site at TA-54, 


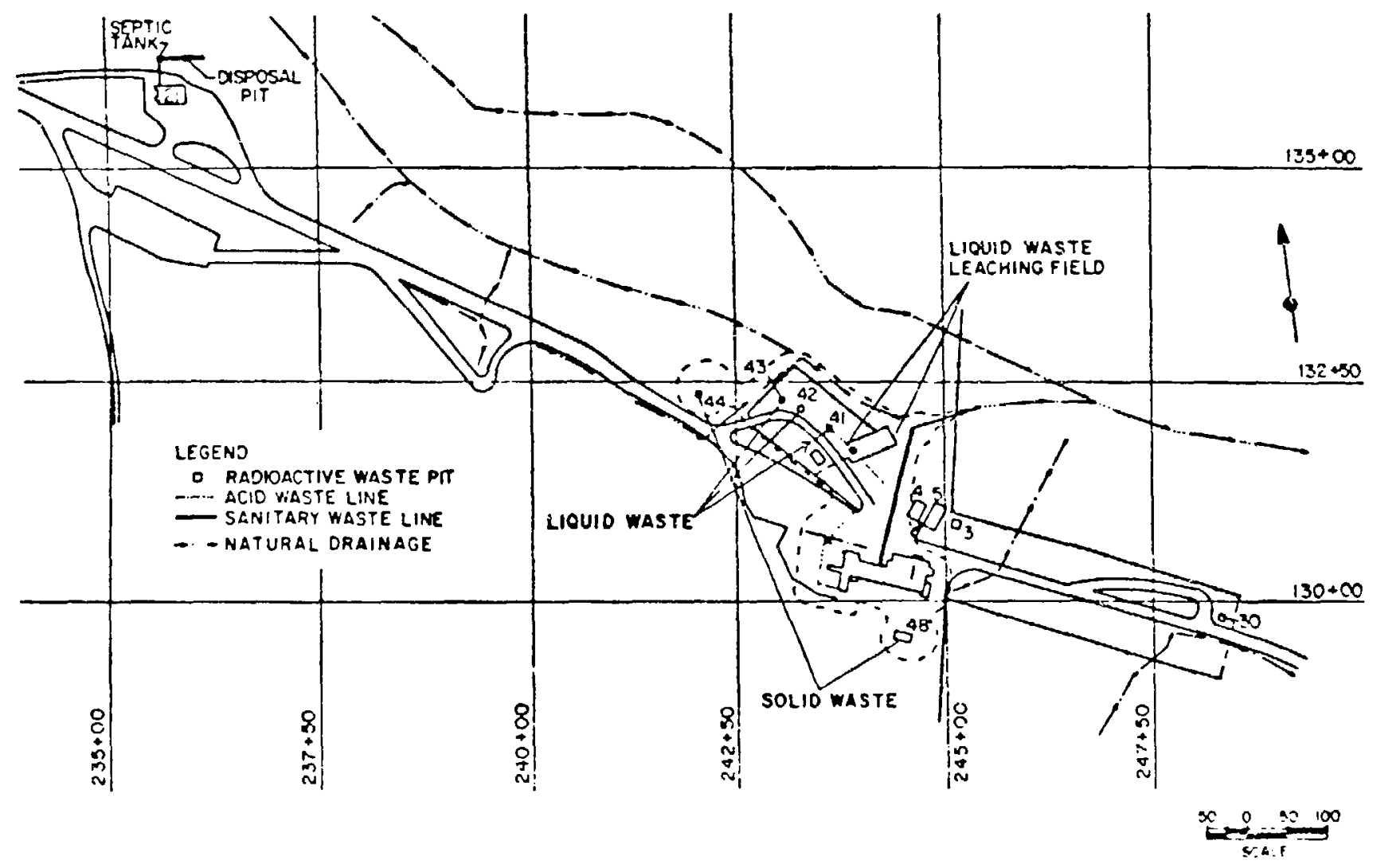

Fig. 4. Waste handling facilities at Bayo Canyon. 
which remains within the present Laboratory boundary. A decommissioning summary is presented in Table I. Some contamination may possibly have been deposited on the surface soil as a result of the burning and excavation operations. However, once decommissioning was completed in 1963, no surface contamination could be detected in Bayo Canyon with portable instruments then in use. (Such survey meters should have been able to detect from roughly $2 \mathrm{nCi}$ at contact to roughly $20 \mathrm{nCi}$ at $1 \mathrm{~m}$ of ${ }^{90} \mathrm{Sr}$ spread uniformly on a smooth, dry surface of low atomic number. Any departure from such ideal conditions, as would be the case in field situations, would raise the detection limit appreciably.)

During the decommissioning, the highest levels of radioactivity were found associated with the acid sewer lines and waste disposal pits, while low levels were found around the shot pads and some buildings. An attempt was made to remove all materials, including soil, that showed detectable contamination. Radiation levels encountered during excavation of waste pit TA-10-48 and the tank farm area $r$ anged as high as $35 \mathrm{mrad} / \mathrm{h}$. Some subsurface contamination was left in the excavations of waste pit TA-10-48 (excavated to $8 \mathrm{~m}$ deep) and the tank farm (excavated to $6 \mathrm{in}$ deep). The bottom of the TA-10-48 excavation read $1.5 \mathrm{mrad} / \mathrm{h}$, and samples from the first $1.2 \mathrm{~m}$ below the bottom (9 $\mathrm{m}$ below ground) ranged from 0 to $300 \mathrm{pCi}{ }^{90} \mathrm{Sr}$ per gram of soil. The bottom of the tank farm excavation also read $1.5 \mathrm{mrad} / \mathrm{h}$. Both excavations were backfilled with uncontaminated soil from other parts of the canyon.

Because of the wide dispersal of debris by the tests and continuing natural erosion processes, a reasonable probability exists that some high-explosive and some potentially radioactive materials remained in the canyon after decommissioning. Thus, periodic surface surveys and searches were conducted in 1966, 1967, 1971, 1973, 1975, and 1976. During such surveys, a number of additional pieces of debris were located, with only a few of them being contaminated with ${ }^{90} \mathrm{Sr}$ or including normal or depleted uranium.

\subsection{Need For Action}

\subsubsection{Radiological Risk.}

2.2.1.1 Method of Estimating Risk. Using the data from the radiological survey, ${ }^{1}$ which is reviewed in Section 4.7 , the radiological risk from residual contamination in Bayo Canyon was evaluated for the three proposed alternatives (Section 3.0). These alternatives were considered in light of two potential uses of the Bayo Site: (1) undeveloped County land open to recreationa? use (status quo) and (2) development as a residential area for as many as 400 homes. Groups of people considered at risk from exposure to radioactive material in Bajo Canyon were identified. Exposure pathways by which each group could receive radiation doses were analyzed, and maximum radiation doses were calculated. 
TABLE I

SIGNIFICANT STRUCTURES RECOMMISSIONED AT BAYO SITE

\begin{tabular}{|c|c|c|c|c|c|}
\hline $\begin{array}{l}\text { Structure } \\
\text { Number }\end{array}$ & $\begin{array}{r}\text { Structure } \\
\text { Nomenclature } \\
\end{array}$ & $\begin{array}{c}\text { Date } \\
\text { Removed } \\
\end{array}$ & $\begin{array}{c}\text { Potential } \\
\text { Contaminatior } \\
\end{array}$ & & Disposition \\
\hline TA-10-1 & $\begin{array}{l}\text { Radiochemistry } \\
\text { laboratory }\end{array}$ & 1963 & $\begin{array}{l}140 \mathrm{Ba}, \quad{ }^{140} \mathrm{La} \text {, } \\
\text { uranium }\end{array}$ & ${ }^{90} \mathrm{Sr}$ & $\begin{array}{l}\text { Burned, debris } \\
\text { to Area G dis- } \\
\text { posal pit; TA-54 }\end{array}$ \\
\hline$T A-10-2$ & Source storage & 1963 & $140 \mathrm{Ba}, \quad{ }^{140} \mathrm{La}$, & ${ }^{90} \mathrm{Sr}$ & $\begin{array}{l}\text { Burned, debris } \\
\text { to Area G dis- } \\
\text { posal pit, TA-54 }\end{array}$ \\
\hline $\begin{array}{l}\text { TA-10-3 } \\
\text { TA-10-4 } \\
\text { TA-10-5 } \\
\text { TA-10-6 }\end{array}$ & Storage & 1960 & $\begin{array}{l}140 \mathrm{Ba}, \quad{ }^{140 \mathrm{La}}, \\
\text { uranilim }\end{array}$ & ${ }^{90} \mathrm{Sr}$ & $\begin{array}{l}\text { Burned, debris } \\
\text { to Area G dis- } \\
\text { posal pit, TA-54 }\end{array}$ \\
\hline TA-10-7 & $\begin{array}{l}\text { Tractor shed } \\
\text { (plutonium, spi11) }\end{array}$ & 1963 & $\begin{array}{l}140 \mathrm{Ba}, \quad{ }^{140 \mathrm{La}}, \\
\text { uranium, } 239 \mathrm{Pu}\end{array}$ & ${ }^{90} \mathrm{Sr}$ & $\begin{array}{l}\text { Burned, debris } \\
\text { to Area G dis- } \\
\text { posal pit; TA- } 54\end{array}$ \\
\hline \multirow[t]{4}{*}{ TA-10-21 } & Personnel building & 1963 & $\begin{array}{l}140 \mathrm{La},{ }^{90} \mathrm{Sr} \text {, } \\
\text { uranium }\end{array}$ & & $\begin{array}{l}\text { No record of } \\
\text { disposal }\end{array}$ \\
\hline & Acid waste system & 1963 & $140 \mathrm{Ba},{ }^{140 \mathrm{La}}$ & ${ }^{90} \mathrm{Sr}$ & $\begin{array}{l}\text { Removed to Area G } \\
\text { pit, TA-54 }\end{array}$ \\
\hline & Sanitary waste system & 1963 & $140 \mathrm{Ba}, \quad 140 \mathrm{La}$, & ${ }^{90} \mathrm{Sr}$ & $\begin{array}{l}\text { Removed to Area G } \\
\text { pit, TA-54 }\end{array}$ \\
\hline & Waste pits & 1963 & ${ }^{140} \mathrm{Ba}, \quad{ }^{140} \mathrm{La}$ & ${ }^{90} \mathrm{Sr}$ & $\begin{array}{l}\text { Removed to Area G } \\
\text { pit, TA-54 }\end{array}$ \\
\hline
\end{tabular}


The largest health risk resulting from residual Bayo Canyon contamination is to potential residents of the area. The added lifetime risk is estimated to be one chance in 11000000 of dying from cancer for a year of exposure at the maximum dose levels. For comparison, the added lifetime cancer risk to potential residents incurred from each year of exposure to naturally occurring background whole body radiation is one chance in 63000 . These risks are summarized in Table II, which also contains a list of other risks encountered during everyday life.

Two types of radiation exposure were considered: lifetime chronic exposure and shorter term exposure limiled in time. For chronic exposure, such as that caused by living in the contaminated area, a continuous intake of $90 \mathrm{Sr}$ and $239 \mathrm{U}-234 \mathrm{U}$ was assumed to occur for a 70 yr lifetime. The highest annual dose received during this $70-y r$ pe.iod was calculated and compared with DOE Radiation Protection St andards (RPS), ${ }^{4}$ which limit annual radiation doses to members of the public. These doses were then used for the risk estimate.

Shorter term exposures could occur to groups such as construction workers building homes or installing utilities in the area. Typically, adults would be involved in these activities. During the exposure period, individuals would inhale or ingest radioactive material, but intake would cease after termination of the particular activity. The ${ }^{238} \mathrm{U}-234 \mathrm{U}$ and ${ }^{90} \mathrm{Sr}$ absorbed by the body during the exposure, however, would continue to irradiate the organs in which they were deposited. To account for this extended irradiation period, the 50-yr dose commitment was used in calculating the dose. This dose commitment is the total dose resulting from an intake of radioactive material that an organ would receive in the 50 yr following the exposure.

If the limited exposure scenario were to last longer than a year, the 50-yr dose commitment per year of exposure was calculated. This dose was used in estimating the health risk from the shorter term exposures and was compared with the DOE RPS. Because the 50-yr dose commitment is larger than the actual dose received in a year, use of the dose commitment for comparison with the RPS is a conservicive procedure protective of public health.

Health risks from radiation exposure were calculated from risk factors published by the International Commission on Radiological Protection (ICRP). ${ }^{5}$ These factors give the lifetime risk of radiationinduced cancer mortality in various organs per unit radiation dose. For leukemia and bone and lung cancer, which are the principal health risks corresponding to exposure to residual Bayo Canyon contaminants, the ICRP recommends age- and sex-averaged risk factors of $2 x$ $10^{-5} / \mathrm{rem}, 5 \times 10^{-6} / \mathrm{rem}$, and $2 \times 10^{-5} / \mathrm{rem}$, respectively. The risk of radiation-induced cancer mortality from uniform whole body radiation is $1 \times 10^{-4} / \mathrm{rem}$. Multiplication of an organ dose calculated above by the appropriate risk factor gives the added lifetime risk of a particular cancer induced by that exposure. 
Maximum Estimated Added Lifetime Risk of Cancer Mortality from Annua? Radiation Exposure

Group
$\begin{aligned} & \text { Potential resident } \\ & \text { of Bayo Canyon }\end{aligned}$
Potential resident
of Bayo Canyon

Individual Increased Chance of Death Caused by Selected Activities ${ }^{a}$
Increased Chance of Death

Smoking 1 pack of cigarettes (cancer, heart disedse) Drinking $1 / 2$ liter of wine (cirrhosis of the liver) Chest $x$ ray in good hospital (cancer)

Travelling 10 miles by bicycle (accident)

Travelling 1000 miles hy car (accident)

Travelling 3000 miles by jet (accident, cancer)

Eating 10 tablespoons of peanut butter (liver cancer)

Eating 10 charcoal broiled steaks (cancer)
Adjitional Lifetime Cancer Risk/Year of Exposure

$9.0 \times 10^{-8}$

$1.6 \times 10^{-5}$

$\begin{array}{lc}\text { US Average Individual Risk of Death in } 1 \text { Yr Due to Selected Causes } \\ \text { Cause } & \text { Annual Risk of Death } \\ \text { Motor vehicle accident } & 2.5 \times 10^{-4} \\ \text { Accidental fall } & 1 \times 10^{-4} \\ \text { Fires } & 4 \times 10^{-5} \\ \text { Drowning } & 3 \times 10^{-5} \\ \text { Air travel } & 1 \times 10^{-5} \\ \text { Electrocution } & 6 \times 10^{-6} \\ \text { Lightning } & 5 \times 10^{-7} \\ \text { Tornadoes } & 4 \times 10^{-7}\end{array}$

a Taken from DOE/EV-0005/30 (May 1981). 
Risks are calculated for the various groups of indivicials exposed to radiation from Bayo Canyon. For perspective, the annual health risk from natural background radiation and selected risks commonly encountered in everyday activities are also presented (Table II).

\subsubsection{Results of Dose Calculations. Survey results at}

Bayo Canyon showed traces of $90 \mathrm{Sr}$ and uranium contamination in surface soil $(0-30 \mathrm{~cm})$ over approximately a $1.4 \times 10^{6} \mathrm{~m}^{2}$ area and low-level subsurface contamination, generally at depths greater than $100 \mathrm{~cm}$, in a more limited area within approximately $10 \mathrm{~m}$ of TA-10-1 and its waste hardling facilities (Section 4.7). 1 This section reports results of dose calculations for exposure scenarios associated with the surface and subsurface contamination. A detailed description of the dose calculation procedures and assumptions used for each scenario is given in Appendix B. Results of the pathway analysis are summarized in Table II.

Two principal uses of Bayo Canyon have been considered.

(1) Undeveloped Land. If Bayo Canyon remains in its current undeveloped state, the potentially exposed groups in the general public are (1) the occasional recreational users of the canyon and (2) the residents in LoS Alamos townsite who live on mesas adjacent to Bayo Canyon.

The occasional recreational users who venture into Bayo Canyon for such activities as hiking, picnicking, and trail riding could be exposed to increments of external penetrating radiation or to increments of airborne contamination above natural background because of residual surface contamination from strontium and uranium. Typically, these users are present in the canyon for only a few hours at a time on an infrequent basis. Thus, potential exposures to such users would be considerably less than those that could be recieived by permanent residents should Bayo Canyon be developed. Because measurements of airborne radioactivity from ${ }^{90} \mathrm{Sr}$ and uranium showed no elevation in the vicinity of Bayo Canyon, no significant increment of dose to present mesa residents is attributable to residuals of Bayo operations.

(2) Developed Land. If Bayo Canyon is developed for residential and Tight commercial use, the potentially exposed groups in the general public are (1) residents, (2) construction $p^{-}$onnel, and (3) persons employed in the commercial es ablishments. These exposures are typically chronic exposures rather than occasional exposures common to recreational use. Residents and employees other than the construction workers will be present in the canyon 8 or more hours a day for 50 weeks or more per year and possibly for 
many years. Construction workers will be present for perhaps 8 yr during development.

\subsection{Doses from Surface Contamination.}

2.2.1.2.1.1 External Penetrating Dose. Most of Bayo Canyon, including the portion used or affected by experinental operations, has a higher natural background of external penetrating radiation than typical in the townsite areas of Los Alamos or White Rock or on mesa tops. This is due in part to higher concentrations of naturally occurring radionuclides in the geologic formations surrounding the former operations site. It is also due in part to ditferences in the geometry of the canyon situation, whereby radiation is received from the canyon walls as well as the floor. The available datal indicate that average penetrating radiation in the canyon bottom is $21 \pm 2 \mu R / h$, with somewhat higher values observed on the talus slopes. The level of external penetrating radiation at the operational area does not show a statistically significant, instrumentally measurable difference from other parts of the canyon. The canyon as a whole exhibits levels about 13\% greater than observed in the townsite areas. Theoretical estimates can be made of penetrating radiation caused by strontium and uranium debris deposited on soil in the old operational areas. These estimates show that the increments of exposure rate attributable to the residual contaminants are less than the spatial and temporal variation in natural background. The dosimetric consequences of external exposure from the experimental debris remaining in Bayo Canyon are shown in Table III.

The largest incremental contribution to penetrating dose attributable to the former Bayo site is from residual uranium debris. This contribution is about $0.2 \%$ of the penetrating dose that would be received by residents in the area had Bayo Site never existed.

\subsection{Dose from Internal Emitters. Bayo}

Canyon soil is a reservoir that could permit some radioactivity to make its way through various pathways to human tissues. The difference between the mean soil concentration of either $90 \mathrm{Sr}$ or uranium and fallout strontium or naturally occurring uranium, respectively, gives the expected mean concentration of Bayo debris used in this evaluation. The values used are shown in Table IV. The values for debris in the surface layers 0 to $5 \mathrm{~cm}, 0$ to $10 \mathrm{~cm}$, and 0 to $30 \mathrm{~cm}$ are representative of the area within a $450-\mathrm{m}$ radius of the center of the firing site and of the canyon floor from $900 \mathrm{~m}$ upstream beyond the center of the firing sites to $850 \mathrm{~m}$ downstream. The values for debris in the 0 to $122-\mathrm{cm}$ layer, however, are only representative for an area 1 by $10^{4} \mathrm{~m}^{2}$ surrounding the laboratory building, its associated waste disposal facilities, and its contaminated storage buildings. The maximum gross $\beta$ value at or above $244 \mathrm{~cm}$ is $4400 \mathrm{pCi} / \mathrm{g}$ at $244 \mathrm{~cm}$.

These values were used to make exposure evaluations in relation to potential human interaction with each soil layer. All 90Sr values are presumed to be associated with $90 \mathrm{y}$ in secular equilibrium. The 
TAB:E III

ODSE EVALUATION FOR EAYO CANYOA,

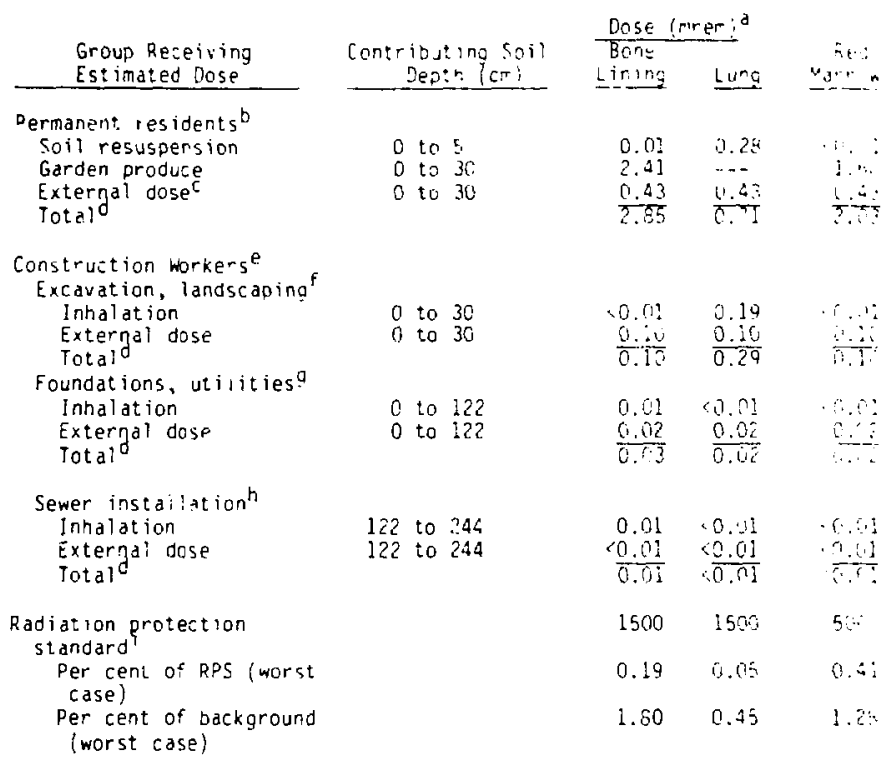

afor permanent residents, the maximum annual dose duriny $70 \mathrm{w}$ of exposure.

All other internal doses are $50-y r$ dose commitments: the dose accumiulated buer

$50 \mathrm{yr}$ as a result of exposure during the first year.

Dypothetical residents of Bayo Canyori assuming development occurs.

$c_{\text {Based on }} 8765 \mathrm{~h} / \mathrm{yr}$ exposure (resident).

dSumation of internal plus external doses.

eHypothetical construction workers in Bayo Canyon assuming developnent occurs.

$f_{\text {Based on }} 2000 \mathrm{~h} / \mathrm{yr}$ exposure.

gaased on $360 \mathrm{n}$ exposure.

$h_{\text {Based on }} 60 \mathrm{~h}$ exposure.

iraken from Ref. 4.

TABLE IY

ABOVE-BACKGROUNO SOIL CONCENTRATIONS ( $\mathrm{PC} / \mathrm{O}$ )

\begin{tabular}{|c|c|c|c|c|}
\hline $\begin{array}{c}\text { Soil Layer } \\
\text { (crii) }\end{array}$ & $90 \mathrm{gr}$ & $238_{\mathrm{UU}}$ & 235 & 234 \\
\hline $\begin{array}{l}0-5 \\
0-10\end{array}$ & $\begin{array}{l}1.0 \\
0.6\end{array}$ & $\begin{array}{l}0.530 \\
0.066\end{array}$ & $\begin{array}{l}0.016 \\
0.002\end{array}$ & $\begin{array}{l}0.334 \\
0.742\end{array}$ \\
\hline $0-30$ & 0.5 & 0.298 & 0.009 & 0.135 \\
\hline $0-122$ & 10 & $\ldots$ & $\ldots$ & $\ldots$ \\
\hline
\end{tabular}


gross $\beta$ value at $244 \mathrm{~cm}$ is presumed to be associated with ${ }^{90} \mathrm{Sr}$ and $90 y$. No likely exposure scenario was thought to be associated with the single maximum sample showing $24000 \mathrm{pCi} / \mathrm{g}$ gross $B$ at a depth of 4.3 to $5 \mathrm{~m}$.

The highest radiation dose was estimated for a potential resident in the canyon. The maximally exposed resident was assumed to spend $100 \%$ of his time for $70 \mathrm{yr}$ in the contaminated area. During that time, he would be exposed to elevated ${ }^{90} \mathrm{Sr}$ and uranium levels in the dust in the air while at home, during outdoor recreation, and outdoors at work. In addition, he would obtain one-half of his vegetables and orle-third of his fruit from his home garden, located in contaminated soil. Radionuclides and concentrations for the $0-$ to $5-\mathrm{cm}$ soil 1 ayers were used for the inhalation exposure, and from the 0 - to $30-\mathrm{cm} 1$ ayer for garden produce. The highest annual radiation dose for the 70-yr exposure time was calculated for both the inhalation and ingestion pathways and is presented in Table III. Bone lining is the organ receiving the highest dose, which is some $2.85 \mathrm{mrem} / \mathrm{yr}$, or $0.18 \%$ of the RPS.

Geileral exposure of construction crews to Bayo debris would be expected diring construction, which could last several years. Exposure would come from aerosols generated by excavation work. Becruse surface deposited Bayo debris is most prevalent in the top 30 $\mathrm{cm}$. it would be disturbed by essentially all excavation work.

Doses to construction workers were calculated using an average dust loading of $400 \mathrm{\mu g} / \mathrm{m}^{3}$ and a breathing rate $(43 \mathrm{l} / \mathrm{min}$ ) typical of relatively demanding physical work. The annual exposure time was 2000 $\mathrm{h} / \mathrm{yr}(40 \mathrm{~h} / \mathrm{wk}$ for $50 \mathrm{wk} / \mathrm{yr})$. The airborne dust was assumed to be contaminated with ${ }^{90} \mathrm{Sr}$ and uranium at levels found in the 0 - to $30-\mathrm{cm}$ soil layer, resulting in inhalation of these radionuclides by the workers and in a resultant dose. Fifty-year dose cominitments per year of exposure were calculated for this scenario. The organ whose dose is the highest fraction of the RPS is the lung, which receives 0.19 mrem/yr, or $0.01 \%$ of the RPS.

\subsection{Doses from Subsurface Contamination. Limited} areas have elevated $90 \mathrm{sr}-90 \mathrm{Y}$ concentrations below a $30-\mathrm{cm}$ depth. The area potentially involved is restricted to that which could have been affected by subsurface deposition.

Doses were calculated for two scenarios: excavation at $122 \mathrm{~cm}(4$ $\mathrm{ft}$ ), where average $90 \mathrm{Sr}$ concentrations are $17 \mathrm{pCi} / \mathrm{g}$, and at $244 \mathrm{~cm}$ (8 $\mathrm{ft})$ at $1100 \mathrm{pCi} / \mathrm{g}$. Uranium is at background levels at these depths. Exposure times were $360 \mathrm{~h}$ and $60 \mathrm{~h}$, respectively, corresponding to the times needed to construct foundations and utilities for six small homes and to install sewer lines and manholes (Appendix B). The breathing rate and dust loading were the same as those used for construction workers. 
Calculated 50-yr dose conmitments are presented in Table II. The highest dose is to bone lining, $0.03 \mathrm{mrem}$ or $0.002 \%$ of the RPS.

Under Alternative 2 (Section 3.0), contaminated subsurface soil would be removed and replaced by clean fill so that cleanup 1 imits of $100 \mathrm{pCi} / \mathrm{g}{ }^{90} \mathrm{Sr}$ would be met. This would reduce the inhalation doses calculated for excavation at $8 \mathrm{ft}$ by at least a factor of $100 / 110 \mathrm{u}$. The actual reduction would depend on how far below the $100 \mathrm{pCi} / \mathrm{g}$ limit the "as left" soil concentrations would be.

Dose pathways involving resuspension of contaminated soil by wind, or growing of contaminated produce, do not apply to subsurface contamination. While wind and water erosion may eventually expose this soil, above-background ${ }^{9} \mathrm{Sr}$ concentrations would have decayed to negligible levels in the time needed for the erosion to occur.

\subsubsection{Health Risks from Residual Bayo Canyon Con-}

tamination. The highest risk resulting from calculated doses occurs to the potential resident, who receives a maximum annual dose of ?.4 mrem to the bone, $1.6 \mathrm{mrem}$ to red marrow, $0.3 \mathrm{mrem}$ to the lung from ingestion and inhalation, and $0.4 \mathrm{mrem}$ to the whole body during 70 yr of exposure. Using the ICRP risk factors, these doses correspond to a one in 11000000 additional lifetime risk of dying from a radiation-induced cancer for each year of exposure to Bayo Canyon residue. Risks associated with other exposure scenarios, such as those involving construction workers, are appreciably lower.

This risk can be compared to the risk of dying from cancer induced by exposure to background radiation. Background external penetrating radiation in Bayo Canyon is $183 \mathrm{mrem} / \mathrm{yr}, 1$ of which 66 $\mathrm{mrem} / \mathrm{yr}$ is cosmic and $117 \mathrm{mrem} / \mathrm{yr}$ terrestrial. The background external radiation dose to a potential resident is $134 \mathrm{mrem} / \mathrm{yr}$, where cosmic radiation has been reduced by $10 \%$ to account for shielding by structures, terrestrial radiation by $20 \%$ because of shielding by structures, and an additional $20 \%$ to account for self-shielding by the body. ${ }^{6}$ Internal radiation is approximately $24 \mathrm{mrem} / \mathrm{yr} .{ }^{6}$ Residents in Bayo Canyon would then receive approximately $158 \mathrm{mrem} / \mathrm{yr}$ whole body background diation. The total risk of dying from a cancer induced by natural $t$.ckground whole body radiation is one chance in 63000 for each year of exposure.

Additional perspective is offered by comparison of the radiation risk to a potential Bayo Canyon resident with other risks normally encountered in everyday life. A list of the risks is presented in Table II. The annual cancer risk to a maximally exposed individua? in Bayo Canyon is on the order of his being struck by lightning.

2.2.2 Criteria upon Which Cleanup Action is Based. Alternative 2 would require cleanup of contaminated soi containing abovebackground soil concentrations of ${ }^{90} \mathrm{Sr}$ and ${ }^{238} \mathrm{U}-234 \mathrm{U}$ to at least 100 $\mathrm{pCi} / \mathrm{g}$ and $40 \mathrm{pCi} / \mathrm{g}$, respectively. These levels apply when either $90 \mathrm{Sr}$ or ${ }^{238} \mathrm{U}-23^{4} \mathrm{U}$ is present singly. When both ${ }^{90} \mathrm{Sr}$ and ${ }^{238} \mathrm{U}-{ }^{234} \mathrm{U}$ are 
present, the critera would be reduced proportionately. ${ }^{2}$ Tiese cieanup criteria, derived by Healy, Rodgers, and Wienke, 7 were cilculated by determining what levels in soil of $90 \mathrm{Sr}$ or $238 \mathrm{U}-234 \mathrm{U}$ could result in a member of the public receiving an annual dose to any organ greater than 500 mrem during a 70-yr lifetime. This $500 \mathrm{mrem} / \mathrm{yr}$ jose for any organ is based on recommendations of the National Council on Radiation Protection and Measurements ${ }^{8}$ for dose limits for members of the public.

Representative pathways by which individuals could receive radiation doses from exposure to Bayo Canyon debris were analyzed. Parameters describing the exposure were chosen to reasonably estimate the minimum concentration that would result in this dose. These included assuming that the maximally exposed individual lived and worked in the contaminated area for $100 \%$ of the time for $70 \mathrm{yr}$, and that during this time he obtained $50 \%$ of his vegetables and $33 \%$ of his fruit from a garden located in the contaminated zone.

A detailed description of the methods used in arriving at these criteria is given in Appendix B. The dose calculation procedures and assumptions used in their derivation also were used in arriving at the pathway dose estimates in the previous section.

\subsection{Other Agencies Involved in Implementation of the Proposed Action}

The $T$ and in Bayo Canyon where the former TA-10 site was located is owned by Los Alamos County. Although the land presently is used only for recreational purposes, the ultimate use probably will be residential development. 9 Therefore, there must be interaction and cooperation between DOE and the County to implement the selected alternative.

\subsection{ALTERNATIVES}

There are five basic alternatives that can be modified to produce a range of alternatives for a given site. Modification or elimination of alternatives is based on site-specific conditions. The five basic alterriatives are as follows.

(1) No action.

(2) Minimal action--Limit public exposure to radioactive sources.

(3) Stabilization/entombment--Cover contamination with clean soil or encapsulate it.

(4) Partial decontamination--Remove easily accessible or potentially active sources to prevent further contamination. 
(5) Decontamination and restoration--Remove and rehabilitate all contamination to make site available for unrestricted use.

On the basis of these basic alternatives and the conditions in Bayo Canyon, Ford, Bacon \& Davis Utah has proposed three working alternatives. 2 These alternatives are discussed in the following sections, and a summary of the actions associated with each option and the advantages and disadvantages associated with each option is presented in Table $V$.

\subsection{Alternative I (Preferred Alternative)--Minimal Action}

This alternative is derived from basic alternative 2 . In this alternative, a 0.6-hectare area encompassing the old radiochemistry laboratory and solid and liquid waste disposal sites will be set aside as a restricted area and retained under County ownership. The rest of the canyon will be available for recreational purposes or residential development. Thus, the area of subsurface contamination will be isolated. County use of the restricted area will be confined to park land, tennis courts, etc., which will preclude disturbance of the subsurface contamination. Based on a half-life of 28 yr for ${ }^{90} \mathrm{~s} r$, approximately 160 yr will be required for the activity level to decay to below $100 \mathrm{pCi} / \mathrm{g}$, at which time the restricted area can be released for unrestricted use.

See Table $V$ for a tabulation of the required actions associated with this alternative and the advantages and disadvantages associated with it.

\subsection{Alternative II-Decontamination and Restoration with Disposal}

This alternative is derived from basic alternative 5. It requires subsurface decontamination. In the area of subsurface contamination, excavation would continue to the depth necessary to reduce contamination to working criteria levels. Based on the radiological survey data, the depth of excavation could extend down to about $12 \mathrm{~m}$. According to the Ford, Bacon, \& Davis Utah report, 2 the maximum volume of contaminated soil to be removed is about $1160 \mathrm{~m}^{3}$. Some soil would have to be removed and then replaced to gain access to the contaminated soil. The contaminated soil would be hauled to the Los Alamos National Laboratory radioactive solid waste disposal site (TA54), and the resulting pit would be refilled with the uncontaminated material that was excavated and with clean fill material.

After restoration, the site could be released for unrestricted use, and consequently, restricted use of the 0.6-hectare area of subsurface contamination by Los Alamos County would be unnecessary. Periodic surveillance and monitoring would not be required.

See Table $V$ for a tabulation of the required actions and the advantages and disadvantages associated with this alternative. 
TABLE $V$

ALTERNATIVES, ASSOCIATED ACTIONS, AND ADVANTAGES AND DISADVANTAGES

$\frac{\text { Alternative }}{\text { I }}$

Mininal Action

\section{II}

Decontamination and Restoration

No Action

\section{Associated Actions}

1) Maintain County ownership of restricted area for 160 yr.

2) Install monument markers on restricted area.

3) Provide surveillance during monument installation annual radiological monitaring and quarterly surveillance thereafter.

1) Remove subsurface contanination as necessary to meet guideline criteria.

2) Provide clean backfill.

3) Dispose of contaminated soil.

4) Rehabilitate impacted area.

5) Provide radioluilical surve support and surveillance.

6) Obtain DOE certification of decontaninated area.

None
Advartages

1) Low cost.

2) Accomplished quickly.

3) Administrative control (County ownership) of restricted area limits likelihood of access to subsurface cont arnination.

4) Essentially no envi:onmental impact.

1) Permanent solution to problem.

2) No ongoing surveillance required.

3) County ownership of restricted area not required.

4) Entire Bayo Canyon site available for restrirted use.

1) No cost.

2) No new environmental impacts.

3) Accomplished immediately.

\section{Disadvantages \\ 1) Subsurface cortaniration remains with poter? for disturbance. \\ 2) Contaminated areajuse re- stricted for about 160 yr.}

3) Surveillance and monitoring required.

4) County must maintain title to restricted area.

5) Cost of long-term monitoring and surveillance.

1) Highest cost option.

2) Greatest short-term envirunmental impact.

3) Highest potential for accidents.

1) Subsurface contamination remains with potential for spread of contaminants. No restricted ase.

2) Strontium-90 contamination does not decay to $100 \mathrm{pCi} / \mathrm{g}$ for $160 \mathrm{yr}$. 


\subsection{Alternative III--No Action}

In this alternative, no action would be taken at the Bayo Canyon Site, which means that the property would remain unchanged and no costs would be incurred. Implementation of this alternative must be considered so that the impacts of the current conditions can L? compared with impacts that would result from implementation of other alternatives.

See Table $V$ for a tabulation of the required actions and the advantages and disadvantages associated with this alternative.

\subsection{AFFECTED ENVIRONMENT \\ 4.1 Land Use}

4.1.1 Bayo Canyon. The section of Bayo Canyon where the old TA10 site was Tocated Ties between Otowi Mesa to the north and Kwage Mesa to the south (Fig. 3). This area is owned by Los Alamos County, which hopes to eventually develop the canyon as a residential ared. ${ }^{9}$ Kwage Mesa is presently designated as a recreational area and thus should not be subject to development. Otowi Mesa is too narrow for development. The upper part of Bayo Canyon, above the old TA-10 site, is narrow, steep-sided, and dark. This area, also owned by Los Al amos County, is probably not suitable for residential development. It is bordered on the north by Barranca Mesa and on the south by North Mesa. North Mesa is the location of the rodeo grounds and horse stables. Barranca Mesa is residentially developed. Bayo Canyon presently is used as a recreational area by hikers, horseback riders, picknickers, etc.

4.1.2 TA-54 (Radioactive Solid Waste Disposal Site). Contaminated soil removed from Bayo Canyon would be taken to TA-54, the radioactive solid waste disposal facility at the Los Alamos National Laboratory, for disposal. TA-54 is located on Mesita del Buey and is entirely on Laboratory property, as snowr -in Eig. 5. At TA-54, the contaminated soil would be handled according to standard disposal procedures. ${ }^{10} \mathrm{~A}$ general description of the TA-54 site is given in a 1977 Los Alamos report on waste disposal sites at the Laboratory. ${ }^{11}$

4.1.3 Transportation Route. The contaminated soil would be transported by truck along the route outlined in Fig. 5. The distance from Bayo Canyon to $\mathrm{TA}-54$ is about $20 \mathrm{~km}$. The transportation route proceeds for most of the way along State Road 4, Alternate State Road 4, and Pajarito Road. These roads are heavily used from 7:00 to 8:30 a.m. and from 3:30 to $5: 30 \mathrm{p.m}$. by Laboratory employees commuting from White Rock, Española, Santa Fe, and other communities in the area. Pajarito Road is located entirely on DOE property and theoretically could be closed to the public. However, this would be of little value because State Road 4 and Alternate State Road 4 could not be closed. 


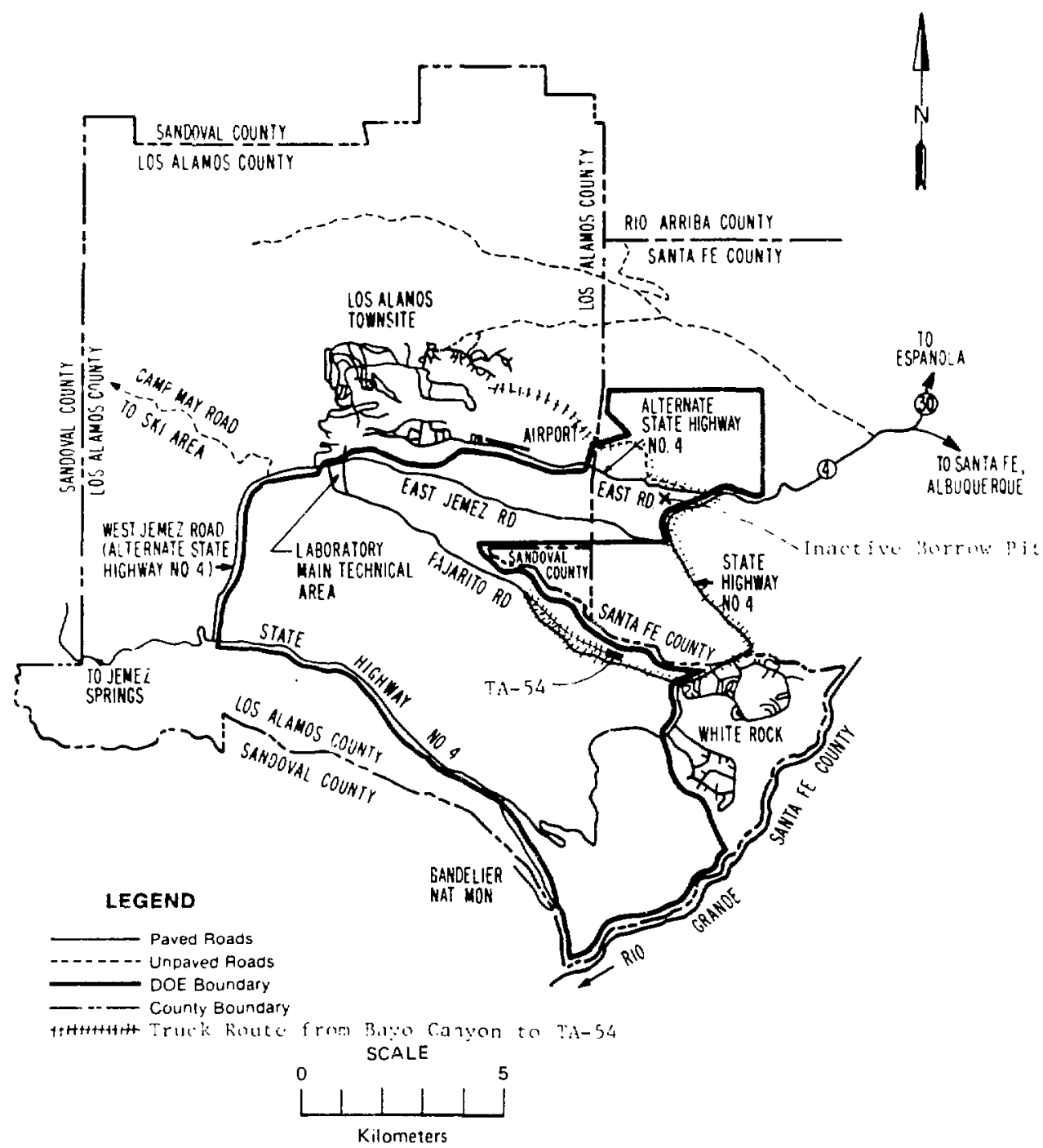

Fig. 5. Location of TA-54 and transportation route from Bayo Canyon. 
4.1.4 Borrow Area. A specific borrow area has not been designated. Any borrow area selected would almost certainly be located on Laboratory property at a site where little reclamation would be necessary. There is an inactive borrow pit in Los Alamos Canyon close to Alternate State Road 4 (Fig. 5), which possibly could be reactivated to provide fill for any Bayo Canyon excavation. This pit is located about $7 \mathrm{kmi}$ from the old TA-10 site.

\subsection{Socioeconomics}

4.2.1 Demography. 12 Los Al amos County has a population estimated by the preliminary 1980 census count at 17586 . Two residential and related commercial areas exist in the county. The Los Alamos townsite, the original area of development (and now including residential areas known as the Eastern Area, the Western Area, North Community, Barranca Mesa, and North Mesa), has an estimated population of 11 0.38. The White Rock Area (including residential areas known as White Rock, La Senda, and Pajarito Acres) has about 6548 residents. About one-third of those employed in Los Alanios commute from other counties. Population estimates for 1980 place 112000 people within an 80-km radius of Los Alamos.

Los Alamos County is a relatively small courtty, $280 \mathrm{~km}^{2}$ in area, which was formed from portions of Santa Fe and Sandoval Counties in 1949. At the present time, slightly under 90\% of County 1 and is under Federal ownership by the Los Alamos National Laboratory, the National Park Service, and the US Forest Service. ${ }^{13}$ Almost all of the privately owned land is already developed. Potential residents of the County are frequently forced to reside in surrounding communities, such as Española and Santa $\mathrm{Fe}$, both because of the shortage of residentiallydevelopable land and because of the high housing costs resulting from this shortage. The County is, thus, interested in any land with potential for residential development, and Bayo Canyon, which is owned by the County, is presently the most likely source of further development.

There is no documented information available on the attitude of the general public toward residential development of Bayo Canyon, with or without cleanup. The County is aware of the existing contamination problem and is awaiting DOE action before pursuing the matter of residential development any further.

4.2.2 Economy. 13 The economy of Los Alamos is based primarily on governmental operations, with the governmental sector directly accounting for about three-fourths of the employment within the county. This employment is associated with the federally funded operations of the LoS Alamos National Laboratory and the associated activities of the $\mathrm{Zia}$ Company, Los Al amos Contractors, Inc. (LACI), EG\&G, and the Los Alamos Area Office of DOE (LAAO). The direct federally funded employment of the Laboratory, Zia, LACI, EG\&G, and LAAO has averaged around 70\% of total employment since 1967. This has a large impact on the area surrounding Los Al amos County, because 
about 35\% of the federally supported workers live outside of Los Alamos County. With in Los Alamos, unemployment is extremely low, averaging around 5\%. The underemployed groups consist primarily of women and adolescents.

4.2.3 Institutional. 13 As the only $\mathrm{H} \mathrm{class}$ county in the State, the powers of the LOS ATamos County government are granted by the State Legislature. The County coordinates planning activities with the North Central New Mexico Economic Development District and the State Planning Office. In 1973, the New Mexico State Legislature passed a law giving the counties responsibility for managing subdivision of 1 and, and Los Alamos County has since enacted subdivision regulations. The County Comprehensive Plan was adopted. in 1964 and revised in 1976. In 1977, the County Zoring Ordinance was revised and adopted.

The Los Alamos County Charter was adopted in 1967. The County is governed by a seven-member County Council, elected at large. Other elected officiais include the County Judge, the County Clerk, the County Assessor, and the County Sheriff. The County Council appoints the chief administrative officers, such as the County Manager, Attorney, and Utilities Manager. The County Council also appoints a five-member Utilities Board, a three-member Board of Equalization, and a Planning Commission.

DOE has administrative control of all of the Laboratory reservation. The responsibilities of the security force include policing activities, generally to prevent the entry of unauthorized persons into restricted areas. There is an agreement with the Los Alamos County Police Department authorizing them to ticket traffic violators on the public access roads across DOE lands. The State Police have authority over state highways, such as State Road 4. The Indian Tribal Police have authority over roads that cross tribal lands. In certain situations, this results in overlapping authorities.

Other Federal agencies having resource management responsibilities in the region include the Forest Service and Farmer's Home Administration of the US Department of Agriculture, the US Geological Survey and National Park Service of the US Department of the Interior, the US Army Corps of Engineers, the Bureau of Reclamation, the Bureau of Indian Affairs, the Fish and Wildlife Service, the Soil

Conservation Service, and the Agricultural Stabilization and Conservation Service.

There are many State agencies that have jurisdiction over particular aspects of the County. The State Engineer Office and the New Mexico Water Quality Control Commission are responsible for water rights and water quality management. The two interstate compacts affecting water use in the region are the Rio Grande Compact of 1938, amended in 1948, and the Costella Creek Compact. There also is one international treaty, the Rio Grande Convention of 1906. Los Alamos 
County is declared part of the Rio Grande Underground Basin. Other important State agencies include the National Resource Conservation Commission, the Department of Game and Fish, the Parks and Recreation Commission, and the: Environmental Improvement Division.

The large percentage of federally owned lands in the region affects the institutional structure. Only Congress is authorized to pass 1 aws affecting the administration of federal property. The Multiple Use and Sustained Yield Act of 1960 and the Classification and Multiple Use Act of 1964 have changed the administration of 1 ands in the region and affected the regional economy.

4.2.4 Community Services. Sewage treatment for the community of Los Alamos is provided by two sewage treatment plant.. One is located near the head of Pueblo Canyon. The effluent from this plant is discharged into Pueblo Canyon during most of the year, but is used to water the municipal golf course during the summer. A larger treatment plant is located just off the eastern end of Kwage Mesa, at the point where the road crosses from Pueblo Canyon into Bayo Canyon. This plant is about $1 \mathrm{~km}$ southeast of the old TA-10 site. It discharges continuously into middle Pueblo Canyon. There are a few small treatment plants on Laboratory property, which discharge into canyons on Laboratory property. The community of White Rock is served by a sewage treatment $p$ lant that discharges into a tributary of the Rio Grande.

Water for Los Alamos County is supplied by a series of wells that penetrate a deep aquifer underlying the Pajarito Plateau at depths ranging from $60 \mathrm{~m}$ at the western edge of the plateau to $180 \mathrm{~m}$ at the eastern edge of the plateau. 13 The water supply system is operated and maintained for DOE by the Zia Company. The County purchases water from DOE and distributes it to users throughout the county. The water suiply system and characteristics are described in a recent report. ${ }^{14}$

Electricity for LOS Alamos County is purchased from DOE and distributed to users throughout the community of Los Alamos. Electricity is supplied to the community of White Rock by the Public Service Company of New Mexico.

Natural gas for Los Alamos County is purchased from DOE and distributed to users throughout the community of LOS Al amos. Natural gas service is supplied to the community of White Rock by the Gas Company of New Mexico.

Telephone service to the entire County is provided by the Mountain Bell Telephone Company.

4.2.5 Archaeology. Cursory searches of Bayo Canyon in the 1950s through 1970s turned up no sites on the canyon floor, although Museum of New Mexico records show several sites on the north side of the canyon that were reported during the early days of the Laboratcry. ${ }^{15} \mathrm{~A}$ 
recent, more thorough search of the canyon resulted in the finding of only one small site west of the vicinity of the Otowi ruins. ${ }^{16}$

In general, there are evidences of sporadic Indian use of the Pajarito Plateau for some $10000 \mathrm{yr}$. One Folsom point has been found, as well as many other archaic varieties of projectile points. Indian occupation of the area occurred principally from late Puebio III (1ate 13 th century) until early Pueblo IV (middle 16th century). Continued use of the region well into the historic period is indicated by pictographic art that portrays horses.

The plateau and canyons consequently are dotted with hundreds of pre-Columbian Indian ruins. Many of the ruins on the southern part of the piateau are encompassed by Bandelier National Monument. Ruins on Laboratory property have been surveyed by Frederick $C$. V. Worman and, more extensively, by Charlie R. Steen, 17 former Chief Archeologist of the Southwest Region of the National Park Service, and subsequently a consultant to the Los Alamos National Laboratory on archeological matters. Portions of the Pajarito Plateau not included in Bandelier National Monument or the Los Alamos National Laboratory have been surveyed more recently by J. N. Hill of the University of California. His findings have not yet been published.

There are three major ruins on Laboratory Property. These are Tsirege, Cave Kiva, and Otowi Ruins. These sites were submitted for consideration for nomination to the National Register of Historic Places in 1973. This nomination is still pending. The Otowi Ruins, a large, unexcavated pueblo, are located about $1.5 \mathrm{~km}$ east of the old TA-10 site, at a point where the canyon wall between Pueblo Canyon and Bayo Canyon is partially broken down.

There are hundreds of other small ruins on Laboratory property, and these also have been submitted for consideration for nomination to the National Register of Historic Places. 18

\subsection{Soil and Geology}

Soils in the vicinity of Bayc Canyon are clay soils on the mesa tops with more sandy soils occurring in the canyon bottoms along the stream beds. The soils are derived from volcanic tuff and, thus, tend to be alkaline in nature, which is unusual for coniferous forest soils. The stream channei consists of granules and sand-sized particles derived from weathering and erosion of the volcanic material. The alluvium is thin in the upper reaches of the canyon and thickens toward the east, becoming tens of feet thick in the lower part of the canyon.

Within Bayo Canyon, weathering has produced a rocky talus slope facing south from Otowi Mesa, whereas a sandy soil has developed on the talus slope facing north from Kwage Mesa. Soil analysis of both the surface and $30-$ to $45-\mathrm{cm}$ soil layers indicates that the soil is reasonably fertile. 19 (See Appendix A.) 
A soil survey ${ }^{20}$ of canyons similar to Bayo Canyon on the Pajarito Plateau indicates that the Bayo Canyon soil would fall into the Puye Series. The description of the Puye Series is as follows. 20

"The Puye series consists of deep, well-drained soils that formed in alluvium in level to gently sloping canyon bottoms near the mountains. Individual areas of Puye soils are 2 to 40 acres in size and occur as long slender bodies. Included with this soil in mapping are areas of soil with up to $10 \%$ slope on the side of the canyons, and a few intermingled areas of Totavi soils adjacent to the north canyon walls; the inclusions make up about 10\% of this mapping unit. Vegetation commonly found on this soil type includes Kentucky bluegrass, western wheatgrass, mountain muhly, ponderosa pine, oak species, and annual grasses and forbs.

"Typically, the surface soil is a dark grayish brown sandy loam, fine sandy loam, or $10 \mathrm{am}$, to $150 \mathrm{~cm}$ or more. Permeability is moderately rapid, the available water capacity is high, and the effective rooting depth is $150 \mathrm{~cm}$ or more. Runoff is very slow, and the erosion hazard is low.

"A typical profile of Puye sandy loam (0 to $5 \%$ slope) is described as follows.

Al $0-15 \mathrm{~cm}$, dark grayish brown sandy loam, very dark grayish brown moist; weak fine granular structure; soft and very friable moist; many fine and very fine roots; neutral; clear smooth boundary.

C 15-152+ cm, dark grayish brown sandy loam, very dark grayish brown moist; massive; soft and very friable moist; common fine and very fine roots; neutral."

The Totavi soils referred to in this description are more gravelly soils, with less organic matter, and tend to support pinonjuniper rather than ponderosa pine communities. The descriptions of the Puye and Totavi soils fit well with the observed vegetational patterns in Bayo Canyon, although much of the old TA-10 site and firing areas are presently inhabited by chamisa (Chrysothamnus) and other disturbed habitat species.

The floor of Bayo Canyon is about $2040 \mathrm{~m}$ above sea level at the location of the 0ld TA-10 site, and the canyon slopes southeastward at a $3 \%$ grade. The mean elevation for Kwage and Otowi Mesas is about 2160 $\mathrm{m}$.

In general, canyons and mesas in the Laboratory area are formed by Bandelier Tuff, composed of the ashfall, ashflow pumice, and rhyolite tuff that form the surface of the Pajarito Plateau. The tuff ranges from nonwelded to welded and is in excess of $300 \mathrm{~m}$ thick in the western part of the Pajarito Plateau, thinning to about $80 \mathrm{~m}$ toward the east above the Rio Grande. It was deposited as a result of a major 
eruption of a volcano in the Jemez Mountains to the west about 1.1 to 1.4 million years ago.

The tuffs lap onto older volcanics of the Tschicoma Formation, which form the Jemez Mountains along the western edge of the plateau, and are underlain by the conglomerate of the Puye Formation in the central and eastern edge along the Rio Grande. Chino Mesa basalts interfinger with the conglomerate along the river. These formations overlie the siltstone/sandstone Tesuque Formation, which extends across the Rio Grande valley and is in excess of $1000 \mathrm{~m}$ thick. ${ }^{12}$

\subsection{Climatology}

4.4.1 General Climate. ${ }^{12}$ Los Alamos has a semiarid, continental mountain climate. The average annual precipitation of $45 \mathrm{~cm}$ is from warm-season convective rain showers and cold-season migratory storms. Forty per cent of the annual moisture total falls during July and August, primarily from afternoon thundershowers. Winter precipitation falls primarily as snow, with heavy annual accumulations of about $130 \mathrm{~cm}$. Heavy localized thundershowers can at times cause severe runoff events through canyons, with attendent scouring of canyon bottoms.

Summers are generally cool and pleasant. Maximum temperatures are usually below $32^{\circ} \mathrm{C}$. The high altitude, light winds, clear skies, and dry atmosphere al low night temperatures to drop into the $12^{\circ} \mathrm{C}$ to $15^{\circ} \mathrm{C}$ $r$ ange. Winter iemperatures are typically in the range from $-10^{\circ} \mathrm{C}$ to $5^{\circ} \mathrm{C}$. Many winter days are clear, with light winds, so that strong solar radiation makes conditions quite comfortable even when air temperatures are cold.

Major spatial and diurnal variations of surface winds in Los Alamos are caused by the complex terrain. Under moderate and strong atmospheric pressure differences, flow is channeled by the major terrain features. Under weak pressure differences, a distinct daily wind cycle exists: a light westerly drainage wind during nighttime hours and a light easterly upslope wind during daytime hours. Interaction of the strong and weak pressure patterns gives rise to westerly flow predominance over the Laboratory and a more southerly predominarice at the east end of the mesas.

4.4.2 Air Quality. No major emission sources exist in the Los Al amos area, although there are routine small releases of radionuclides and other chemicals by the Laboratory. Routine monitoring systems and procedures indicate that, although radiation and radioactivity levels above background $c$ an be detected, no concentration guidelines (CGS) or other applicable standards are being violated. 12

The TA-3 power plant, the Zia Company asphalt plant, other unit operations, and the general status of air quality and Laboratory compliance with air quality regulations recently were reviewed in a 
series of internal memoranda. 21 The basic finding of this review was that emission standards and ambient air quality standards are not being violated in the Los Al amos area. Air quality in the Los Alamos area should continue to be very good because of the proximity of Bandelier National Monument, the WIlderness Area of which is mandated as a Class I area under the Prevention of Significant Deterioration (PSD) provisions of the Clean Air Act. 22

\subsection{Hydrology and Water Quality 12}

In Bayo Canyon, water runoff is intermittent and drains eastward through the canyon. There is water in the canyon only after heavy rainfall or heavy snowmelt. However, although the stream is intermittent, a flood plain above the stream channel occupies a significant portion of the canyon bottom.

The alluvium within the canyon is underlain by volcanic tuff. Many of the canyons support perched aquifers on the tuff within the alluvium, but no such aquifer exists in Bayn Canyon. The main aquifer is located below the tuff, at a depth of abcut $250 \mathrm{~m}$. There is no hydrologic connection between surface water in Bayo Canvon and the main aquifer.

There also is no hydrologic connection between Bayo Canyon and Pueblo Canyon, although the wall between the two canyons is broken down at a point east of the old TA-10 site, in the vicinity of the sewage treatment plant and the Otowi Ruins.

\subsection{Biotic Environmental Factors}

4.6.1 General Ecology. Community types on the Pajarito Plateau range from pinon-juniper woodland with 25 to $30 \mathrm{~cm}$ of rain annually at the eastern, lower part of the plateau to ponderosa pine forest with 45 to $50 \mathrm{~cm}$ annual precipitation at the western, higher edge. The canyons serve as cold air drainage channels from the mountains to the Rio Grande Valley and, thus, tend to be cooler and more moist than the mesa tops above. This allows vegetation characteristic of higher elevations to extend farther eastward along the canyon bottoms.

In Bayo Canyon, the narrow, steep-sided upper part of the canyon is populated with a pine-fir community that is normally located at an elevation above the ponderosa pine forest. The portion of the canyon where the old TA-10 site was located supports the reminants of a ponderosa pine community, in contrast to the pinon pine-juniper woodland found on the mesa tops above and on the drier northern slopes of the canyon. The old firing sites, where the ponderosa pine forest was removed, support a brushy, disturbed habitat community.

\subsubsection{Plants.}

4.6.2.1 Characterization. The steep-sided and narrow upper part of Bayo Canyon is relatively moist and cool and supports a 
pine-fir (Pinus ponderosa, Pseudotsuga menziesii, Abies concolor) forest. As the canyon widens into the section where the old IA-IO site was located, the pine-fir overstory thins and is relegated to the north-facing slope of Kwage Mesa. The canyon bottom supports many large ponderosa pine trees (Pinus ponderosa) scattered throughout the old TA-10 site, except in the vicinity of the old firing sites, where all vegetation was removed during the time period of active site operation. The ponderosa pine gives way to a pinon-juniper woodland (Pinus edulis, Juniperus monosperma) on the drier south-facing slope of Otowi Mesa.

The vegetation in Bayo Canyon has never been characterized. However, a study of the vegetation in Pueblo Canyon recently was completed. ${ }^{23}$ Pueblo Canyon is located one canyon south of Bayo Canyon, and so the vegetation in the two canyons should be similar, particularly because the wall bet veen the canyons is broken down for a considerable distance between the sewage treatment plant at the end of Kwage Mesa and the eastern end of the Big Otowi Ruins. The more mesic vegetation found in Pueblo Canyon because of the sewage treatment plant effluent may not be present in Bayo Canyon, which is drier. Appendix $C$ gives a tabulation of the total plant survey of Pueblo Canyon. The most common shrubs and herbs are listed in Table VI.

4.6.2.2 Rare and Endangered Species. A recent study by Foxx and Tierney 24 has dealt with the status of the flora found on Laboratory property. Some inferences concerning the Bayo Canyon flora can be drawn from this report.

There appear to be no plant species from the Federal Endangered and Threatened Species List present in Bayo Canyon. A species that is being considered for this list, the grama grass cactus (Pediocactus papyracanthus), can be found in Los Alamos, but it is not Tikely to be found in Bayo Canyon as it preferentially inhabits mesa tops.

Table VII lists those plants that could be found in Bayo Canyon and that are protected under New Mexico Statute 45-11. Al though this statute does not have any penalties associated with it, per se, destruction of plants covered by it can result in court action if anyone wishes to bring suit.

None of the $350 \mathrm{plant}$ species submitted by the New Mexico Heritage program for consideration for protection under the Federal Endangered arid Tilreatened Species List are likely to be found in Bayo Canyon, although 27 species on this list have been found in or around Los Al amos County.

\subsubsection{Animals.}

4.6.3.1 Characterization. Little quantitative information concerning the fauna of the Los Alamos area is available. Species lists were presented in the Environmental Impact Statement ${ }^{13}$ for the Los Alamos Scientific Laboratory site. These lists are 
TABLE VI

COMMON HERBS AND SHRUGS OF THE BAYO CANYON AREA

Grasses and Forbs

Andropogon scoparlus - 11ttle bluestem

Bouteloua gractlis - blue grama

Bronus tectorum - cheatgrass

Koelaria crlstata - Junegrass

raraxicum officinale - dandelion

Verbascum thapsts - woolly mullein

Shrubs and Subshrubs

Artemis1a tridentata - b1B sagebrush

Atriplex canescens - saltbush

Chrysothamnus nauseosus - chamisa or rabbltbrush

Fallugia paradoxa - Apache plume

Forestiera neomexicana - New Mextco olive

Gut1errez1a nicrocephala - snakeweed

Prunus virginlana, var. melanocarpa - chokecherry

Quercus gambel11 - Gambel ozk

Quercus undulata - scrub oak

Rhus trilobata - squawbush

Robinia neomexicana - New Mexico locust

D1sturbed Habitat Plants

Artem 1s1a frig1da - wormwood

Chenopod 1um fremont11 - lambsquarters

Chrysops1s villosa - goldenweed

Croton texensis - doveweed

Cryptanthe James11 - James cryptantha

Erodium c1rcutarium - filaree

Helianthus petiolaris - prairie sunflower

Lupinus caudatus - lupine

Mlrabtlis qultiflora - wlld four o'clock

Salsola kal1 - Russian thistle or tumbleweed

V1guiera multiflora - crownbeard

TABLE VI!

PLANTS PROTECTED BY NEW MEXICO STATE LAW THAT MIGHT BE FOUND IN BHYYS CANYON

Asclepia tuberosa - butterflyweed

Castilleja integra - Indian paintbrush

Clemat1s pseudoalpinus - alpine clemat is

Heuchera parvifolla - alumroor

Pulsat 1lia ludov1c1ana - pasquef lower

R1bes cereum - wax currarit

Ribes montigenum - gooseberry currant 
included as Appendix $D$ of this report. The lists are, however, somewhat uncertain. Occurrence of some species has not been verified, although sightings have been reported, and other species that are not on the list may be present.

A biotic survey conducted by Miera et al. 25 in Acid-Pueblo Canyon and other liquid-effluent receiving areas noted the presence of 14 small mammal species, verified by trapping or sighting. These species are listed in Table VIII.

4.6.3.2 Rare and Endangered Species. Table IX gives a 1 ist of endangered and threatened species developed by the New Mexico State Game Commission for northcentral New Mexico. 13 Although several of these species have been documented in Los Alamos County, the only one known to be present in proximity to Bayo Canyon is the peregrine falcon (Falco peregrinus). There is a peregrine falcon aerie in Pueblo Canyon, adjacent to Bayo Canyor, which has been in existence at least since the early 1960s. Bayo Canyon is used as a hunting arta by the falcons.

There is no reason to suspect the presence of other species from Table VI in Bayo Canyon, although the habitat probably would be suitable for animals such as the black-footed ferret, pine marten, red-headed woodpecker, and zone-tailed hawk, if these animals were present in large numbers in Los Alamos County.

\subsection{Summary of Radiological Conditions}

4.7.1 Background Radiation and Radioactivity. Soil in the Bayo Canyon area contains, Tike soil anywhere, trace levels of naturally occurring radioaciivity. Uranium soil concentrations range from 0.5 to $8.1 \mu \mathrm{g} / \mathrm{g}$, thorium from 9.2 to $22.7 \mu \mathrm{g} / \mathrm{g}$, and $40 \mathrm{~K}$ from 29.5 to 37.3 $\mathrm{pCi} / \mathrm{g} .1$ These levels are typical of salic igneous materials, which generally have slightly higher naturally occurring radionuclide contents thar, other soils. ${ }^{6}$ Soil concentrations of ${ }^{90} \mathrm{Sr}$ from fallout vary with depth. Background soil levels for ${ }^{90} \mathrm{Sr}$ and uranium are summarized in Table $X$.

External penetrating radiation in the canyon and surrounding area has high spatial variation for three principal reasons. (1) The soil concentrations of naturally occurring radionuclides discussed above vary over relatively wide ranges. (2) The local topography from one location to the next can be quite different. (A site located in the canyon would receive radiation from the canyon walls as well as the floor, while a location on a mesa top would only receive radiation from the material beneath it.) (3) The 120-m change in elevation between canyon floor and mesa top would affect the level of cosmic radiation. In addition, there is temporal variation from the solar cycle and climatic conditions such as soil moisture and snow cover. In this report, the background external penetrating radiation in the canyon from charged particles and photons is taken to be $172 \pm 13$ 


\section{TABLE VIĩ}

MAMMALS TRAPPED OR SIGHTED IN ACID-PUEBLO CANYON

Eutamius minimus - least chipmunk

Microtus pennsylvanicus - meadow vole

Mus musculus - house mouse

Neotoma mexicana - Mexican woodrat

Peromyscus maniculatus - deer mouse

Peromyscus truei - piñon mouse

Reithrodontomys megalotis - western harvest mouse

Sciurus aberti - tassel-eared squirrel

Sigmodon hispidus - hispid cotton rat

Sorex nanus - dwarf shrew

Spermophilus lateralis - golden-mantled squirrel

Spermophilus variegatus - rock squirrel

Sylvilagus sp. - cottontail rabbit

Thomomys bottae - valley pocket gopher 
TABLE IX

STATE-LISTED ENDANGEREO ANIMAL SPECIES FOR NORTHCENTRAL NEW MEXICO

\begin{tabular}{|c|c|c|}
\hline & $\begin{array}{c}\text { Group } 1 \\
\text { Endangered }\end{array}$ & $\begin{array}{l}\text { Group } 2 \\
\text { Threatened } \\
\end{array}$ \\
\hline Marnmals & $\begin{array}{l}\text { Black-footed ferret } \\
\text { River otter }\end{array}$ & $\begin{array}{l}\text { Pine marten } \\
\text { Mink }^{\mathrm{a}}\end{array}$ \\
\hline Birds & $\begin{array}{l}\text { Peregrine falcon } \\
\text { Whooping crane } \\
\text { White-tailed ptarmigan } \\
\text { Sage grousea } \\
\text { Mexican duck } \\
\text { Bald eagle }\end{array}$ & $\begin{array}{l}\text { Osprey } \\
\text { Red-headed woodpecker } \\
\text { Zone-tailed hawk }\end{array}$ \\
\hline Amphibians & & Jemez Mountain sal amander \\
\hline Fish & $\begin{array}{l}\text { Shovelnose sturgeon } \\
\text { (exterminated) } \\
\text { Bluntnose shiner }\end{array}$ & Suckermouth minnow ${ }^{\mathrm{a}}$ \\
\hline
\end{tabular}

TABLE $X$

CONCENTRATIONS OF ${ }^{90} \mathrm{Sr}$ AND URANIUM IN SOIL

Depth

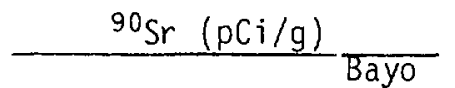

$\frac{\text { Uranium }(\mu \mathrm{g} / \mathrm{g})}{\text { Naturally Bayo }}$

$(\mathrm{cm})$

Mean Fallout Debris

Mean

Occurring Debris

$0-5^{a}$

1.4

0.4

1.0

4.9

3.4

1.6

$0-10^{a}$

0.9

0.3

0.6

3.6

3.4

0.2

$0-30^{\mathrm{a}}$

0.7

0.2

0.5

4.3

3.4

0.9

$0-122^{b}$

10.3

$<0.1$

10.3

a General Bayo site.

b Limited to approximately $90-\mathrm{m}^{2}$ area around disposal pits. 
$\mathrm{mrem} / \mathrm{yr}$. Annual cosmic neutron radiation is approximately $11 \mathrm{mrem}$, so that the total external radiation level is $183 \mathrm{mrem} / \mathrm{yr}$.

\subsubsection{Surface Soil Conditions.}

4.7.2.1 Probability of Surface Contamination Exceeding the Working Criteria. Statistical anaiysis of the surface soil data for ${ }^{0}$ Sr and uranium concentrations indicates that there is little probability of undetected surface concentrations exceeding the working criteria.

The statistical analysis was undertaken because the proposed alternatives do not consider surface cleanup. Surface cleanup was not considered because the radiological surveyl did not report any ${ }^{90} \mathrm{Sr}$ or uranium concentrations above the working criteria. The statistical techniques used were kriging analys is 26 and a 1 inear regression of ${ }^{0} \mathrm{~S} r$ concentration against gross $\beta$ concentration.

Kriging provides isopleths of concentrations as well as isopleths of the upper 95\% confidence bound for tinese predicted values. Thus, the probability that repeated sampling of the area would show concentrations greater than the upper 95\% confidence bound is 0.025 (because there is also 0.025 probability that concentrations may be less than the $95 \%$ confidence lower bound). Such confidence bound isopleths are shown in Figs. 6 and 7. The kriging analys is was based on concentration averaging over a $1.5-\mathrm{m}(5-\mathrm{ft})$ radius circle.

Figure 6 presents the kriging results for gross $\beta$ concentrations. In the central, roughly circular, area, there is a $95 \%$ probability that the gross $\beta$ concentration would not exceed $0.9 \mathrm{pCi} / \mathrm{g}$ if another sample were taken. Beyond that is an area with a $95 \%$ probability where the gross $\beta$ concentration would not exceed $1.4 \mathrm{pCi} / \mathrm{g}$, and so forth. Figure 8 shows similar results for gross $\alpha$ concentrations.

Concentrations increased with progression away from the center of the firing site area for two reasons. (1) The central portion of this area was more heavily sampled, allowing the prediction of a lower concentration at the $95 \%$ confidence level. (2) The central portion of the firing area received more attention during the original cleanup ar,d demolition activities.

As a follow-up to the kriging analysis, a linear regression of ${ }^{90} \mathrm{Sr}$ concentration against gross $\beta$ concentration was performed, using the data from Tables D-II, D-III, D-IV, D-V, D-VII, D-XII, D-XIV, DXVI, D-XVIII, D-XX, D-XXII, D-XXIV, and D-XX'SI of the radiological survey. I At low gross $\beta$ concentrations, no correlation existed between the two sets of data because of $\beta$ contributions from naturally occurring radioisotopes other than ${ }^{90} \mathrm{Sr}$. At higher gross $B$ concentrations, however, the ${ }^{90} \mathrm{Sr}$ conceritrations were found to be approximately twice the gross $\beta$ concentrations with a correlation coefficient of 0.98 . 


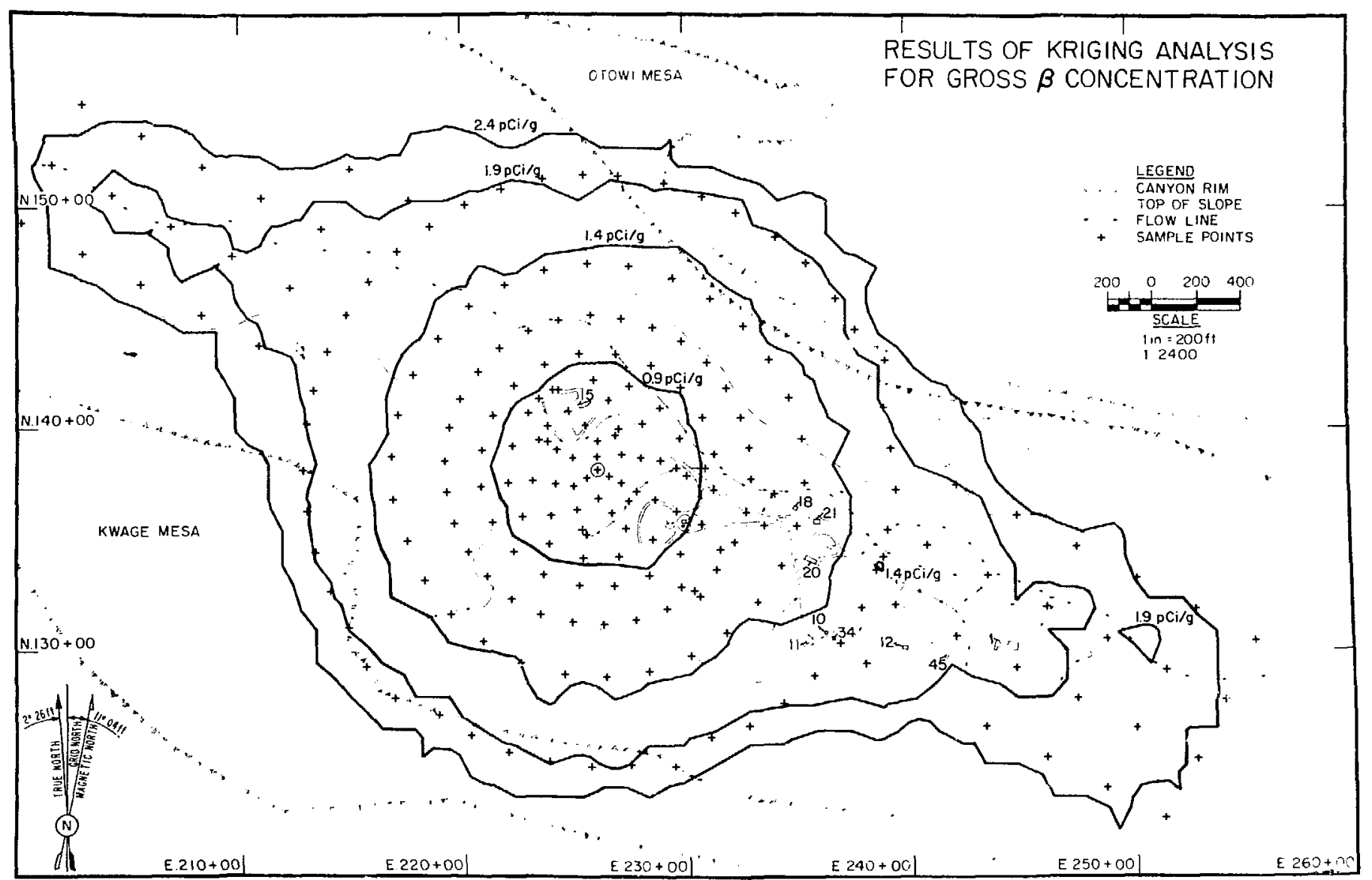

Fig. 6. Surface debris from Bayo Canyon. 


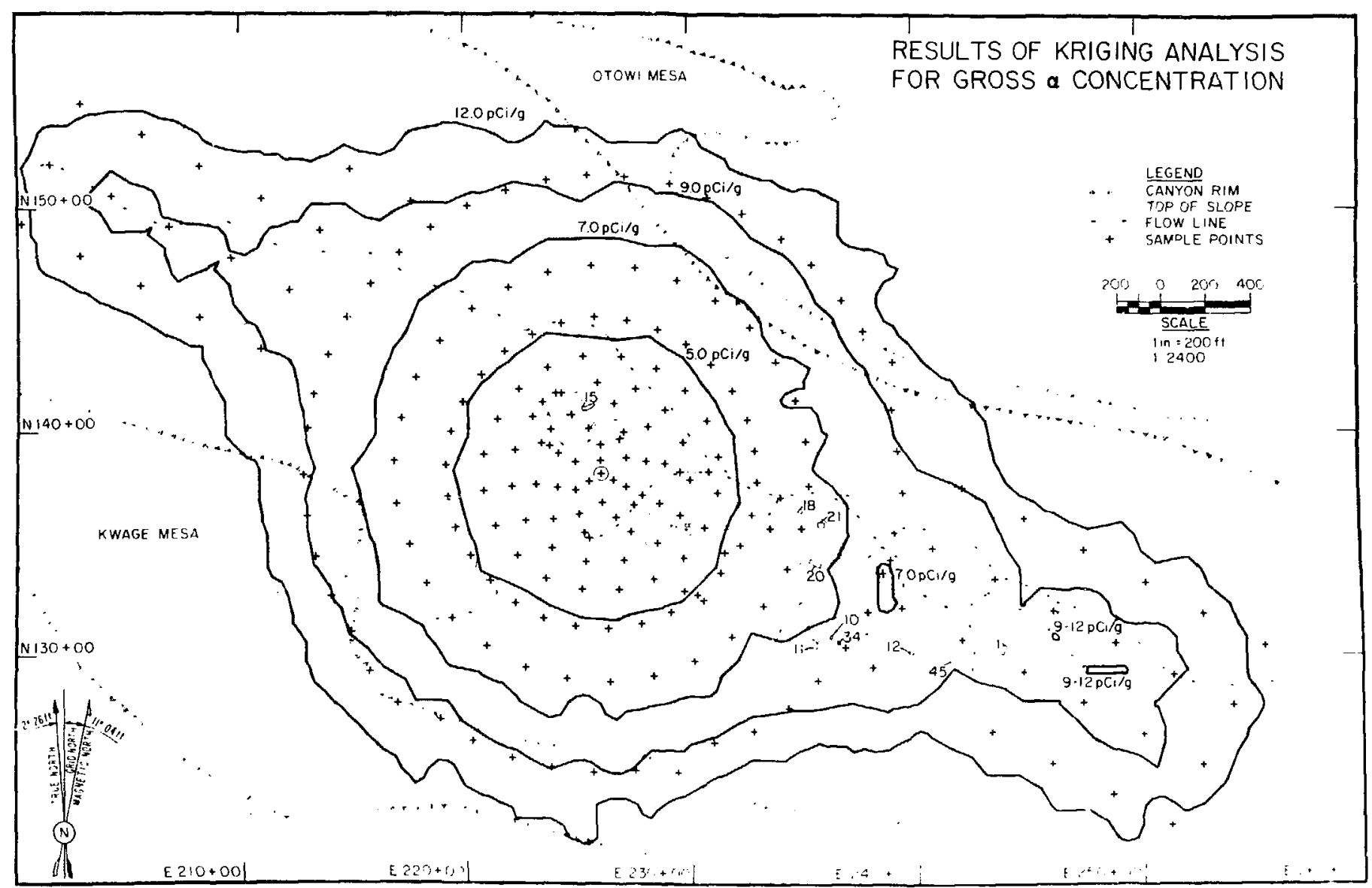

Fig. 7. Confidence boundary isopleths for gross $\beta$ concentrations. 
Thus, some certainty can be attached to the following conclusions.

1. Strontium-90 concentrations are not likely to be much more than twice gross $\beta$ concentrations.

2. Because the highest gross $\beta$ concentration predicted by the kriging analysis, at $95 \%$ probabil. $y$, is $2.4 \mathrm{pci} / \mathrm{g}$, the. highest ${ }^{00} \mathrm{Sr}$ concentration likely $L$. be found should be around $5 \mathrm{pCi} / \mathrm{g}$.

3. Everi if a higher ${ }^{90} \mathrm{~S} r$ concentration does exist, the probability that the working criteria of $100 \mathrm{pCi} / \mathrm{g}$ will be exceeded is very small.

The kriging analysis was not performed directly on the ${ }^{90} \mathrm{Sr}$ data because insufficient ${ }^{90} \mathrm{Sr}$ data were available. All of the sample locations, indicated by +'s in Fig. 6 , were tested with portable instruments that gave gross $\beta$ values. However, only those samples with high gross $\beta$ concentrations were further analyzed for ${ }^{90} \mathrm{~S} r$ concentrations. The ${ }^{90} \mathrm{Sr}$ analys is is a complicated and time-consuming wet chemical analysis, and the gross $\beta$ measurement, which is a very crude ineasurement, was used to screen samples for 90 sr analysis. The crudeness of the instrumental gross $\beta$ analysis aiso is the reason why the ${ }^{90} \mathrm{Sr}$ concentrations appear to be higher than the gross $B$

concentrations.

4.7.2.2 Existing Conditions. The 1977 survey detected traces of $90 \mathrm{sr}$ and uranium debris in the $0-$ to $30-\mathrm{cm}$ layer of soil. This contamination was principally found within the $1.4 \times 10^{6} \mathrm{~m}^{2}$ area covered by the firing site and canyon floor grids.

The 0 - to $5-\mathrm{cm}$ layer appears slightly more burdened with debris than other layers of the $0-$ to $30-\mathrm{cm}$ surface zone, so it is taken as illustrative of them. The mean ${ }^{90} \mathrm{Sr}$ concentration was $1.4 \mathrm{pCi} / \mathrm{g}$, which is about three times the level of local ${ }^{90} \mathrm{Sr}$ from fallout. Of the 50 representative samples from this layer analyzed for ${ }^{90} \mathrm{Sr}, 1$ exceeded 9 $\mathrm{pCi} 90 \mathrm{Sr} / \mathrm{g}$, and 17 exceeded $1.0 \mathrm{pCi} 90 \mathrm{Sr} / \mathrm{g}$. The highest level sample contained $132 \mathrm{pCi}{ }^{90} \mathrm{Sr} / \mathrm{g}$.

The mean uranium level among these 50 samples was $4.9 \mathrm{\mu g} / \mathrm{g}$, which is $44 \%$ greater than the naturally occurring uranium concentration of $3.4 \mathrm{\mu g} / \mathrm{g}$. One sample exceeded $10 \mathrm{\mu g} / \mathrm{g}$, and twenty-one exceeded 4 $\mu \mathrm{g} / \mathrm{g}$.

Uranium and ${ }^{90} \mathrm{Sr}$ soil concentrations from the $0-$ to $10-\mathrm{cm}$ layer and the 0 - to $30-\mathrm{cm}$ layer tend toward lower mean values and less divergence from the mean than those from the $0-$ to $5-\mathrm{cm}$ layer. Radionuclide soil levels are summarized in Table $x$.

Both the vertical and horizuntal distributions of the radionuclides are uneven. As expected, most surface radioactivity was found 
around the firing pads. Results from some 1973 datal indicated that no elevated levels of ${ }^{90} \mathrm{Sr}$ were present in stream channel alluvium $2 \mathrm{~km}$ downstream from the firing sites.

With the exception of the highest ${ }^{90} \mathrm{Sr}$ sample, radiological surveysl have indicated that surface soil concentrations of $90 \mathrm{Sr}$ and uranium are below the cleanup criteria. The area in which the high ${ }^{9} \mathrm{Sr}$ sample of $132 \mathrm{pCi} / \mathrm{g}$ was taken was resampled, and the high analysis was not duplicated. Several supplementary samples taken within $2 \mathrm{~m}$, as well as an adjacent core sample and another portion of the high sample, showed only normal levels of activity.

Eighteen years have elapsed since the last thorough sweep of the old TA-10 site in 1963,27 although biennial inspections with some attendant debris collection were continued until 1975. Indoubtedly, debris will continue to be uncovered in Bayo Canyon with further weathering. That is, the canyon will never be completely free of debris from TA-10 testing. On the other hand, the use of the area by people has left its mark in cans, broken glass, broken clay pigeons from skeet shooting, etc. At some point in time, recreational debris will exceed TA-10 debris. If developed for housing, construction debris will be added.

Based on previous cleanup efforts, several truck loads of weathered surface debris are scattered over a 30-hectare area. Most of this debris is jagged and twisted metal shrapnel wire and cable pieces from explosive tests, although some structural debris also remains. Figure 8 is a photograph of representative pieces of debris collected in October, 1979, in $15 \mathrm{~min}$ in dense vegetative cover near the old firing sites. None of the pieces had measurable radioactive contamination.

To evaluate the radiological impact of the above-background ${ }^{90} \mathrm{Sr}$ and uranium levels in the surface soil, air concentrations of ${ }^{90} \mathrm{Sr}$, uranium, and exterral penetrating radiation were monitored in Bayo Canyon and the surrounding area. Concentrations of airborne gosr were statistically indistinguishable from fallout levels measured at regional northern New Mexico sites and at other North American locations. Uranium levels in air were not statistically different from the concentration expected locally from naturally occurring uranium. Air concentration measurements are summarized in Tables XI and XII.

Measured external penetrating radiation levels at Bayo Canyon are within the range expected for the Pajarito Plateau area. Measurements made with gamma spectroscopy able to identify the radionuclides generating external terrestrial radiation found no detectable levels of radionuclides present in above-background concentrations. Because external radiation levels from Bayo debris are below sensitive instrument detection limits, they were thecretically calculated from the soil concentrations to be $0.43 \mathrm{mrem} / \mathrm{yr}$. Results of both the measurements and the calculations are presented in Table XIII. 


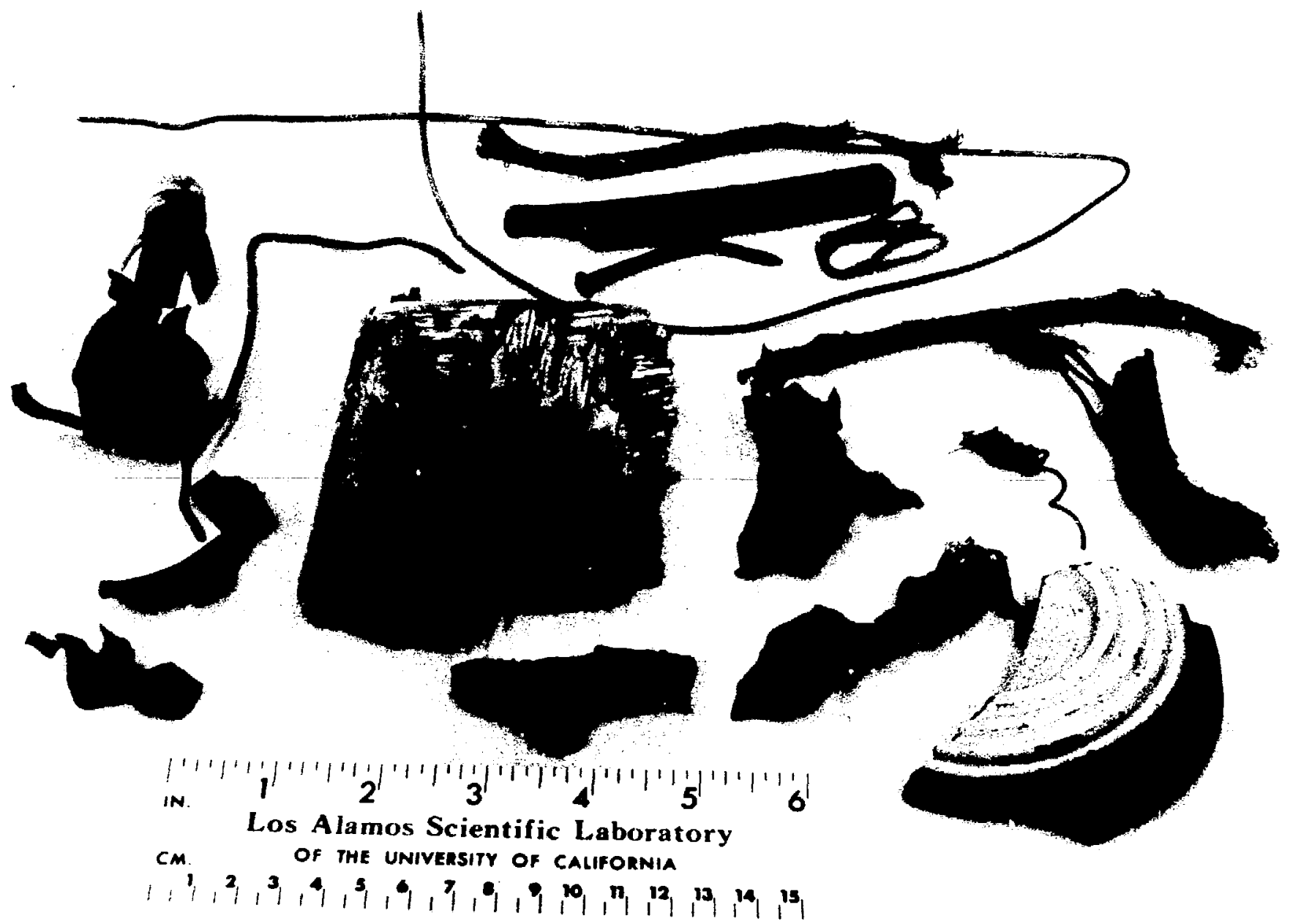

Fig. 8. Confidence boundary isopleths for gross a concentrations. 


\section{TABLE XI \\ COMPARISON OF ${ }^{90} \mathrm{Sr}$ IN SURFACE AIR \\ $\left(\mathrm{fCi} / \mathrm{m}^{3}\right)$}

\begin{tabular}{|c|c|c|}
\hline & Range & $\bar{x} \pm 0$ \\
\hline $\begin{array}{l}\text { Moosonee, Ontario } \\
\text { Helena, Montana } \\
\text { New York, New York } \\
\text { Rocky Flats, Colorado } \\
\text { Richmond, California } \\
\text { Group summary }\end{array}$ & $\begin{array}{l}0.09-0.15 \\
0.17-0.18 \\
0.19-0.24 \\
0.14-0.27 \\
0.14-0.22 \\
0.09-0.27\end{array}$ & $\begin{array}{l}0.13 \pm 0.03 \\
0.18 \pm 0.01 \\
0.21 \pm 0.03 \\
0.21 \pm 0.04 \\
0.19 \pm 0.04 \\
0.18 \pm 0.07\end{array}$ \\
\hline $\begin{array}{l}\text { Española, New Mexico } \\
\text { Pojoaque, New Mexico } \\
\text { Santa Fe, New Mexico } \\
\text { Group summary }\end{array}$ & & $\begin{array}{l}0.17 \\
0.14 \\
0.14 \\
0.15 \pm 0.02\end{array}$ \\
\hline $\begin{array}{l}\text { Bayo Canyon floor } \\
\text { Mesa top (townsite) } \\
\text { Group summary }\end{array}$ & & $\begin{array}{l}0.13 \\
0.09 \\
0.11 \pm 0.03\end{array}$ \\
\hline
\end{tabular}

aEML-339 Department of Energy, Environmental Measurements Laboratory, 4th Quarter 1975.

bLos Alamos Scientific Laboratory Surveillance Net, 4th Quarter 1976. 
TABLE XII

COMPARISON OF TOTAL URANIUM IN SURFACE AIR $\left(\mathrm{pg} / \mathrm{m}^{3}\right)$

\begin{tabular}{|c|c|c|c|}
\hline Station Location & Range & $\bar{x} \pm \sigma$ & $\begin{array}{l}\text { No. of } \\
12-14 \text { Wk } \\
\text { Samples }\end{array}$ \\
\hline \multicolumn{4}{|l|}{ Perimeter Stations $(0-4 \mathrm{~km})$} \\
\hline $\begin{array}{l}\text { Arkansas Avenue } \\
\text { Golf course } \\
\text { Diamond Drive } \\
48 \text { th Street } \\
\text { Fuller Lodge } \\
\text { LA Airport } \\
\text { Gulf station } \\
\text { Acorn Street } \\
\text { Royal Crest } \\
\text { White Rock S.T.P. } \\
\text { Pajarito Acres } \\
\text { Bandelier } \\
\text { Group Summary }\end{array}$ & $\begin{aligned} 27 & -105 \\
40 & -64 \\
50 & -179 \\
39 & -63 \\
64 & -109 \\
40 & -68 \\
51 & -102 \\
9 & -134 \\
-7 & -35 \\
47 & -77 \\
32 & -56 \\
24 & =55 \\
7 & -179\end{aligned}$ & $\begin{aligned} 66 & \pm 4 \\
54 & \pm 3 \\
111 & \pm 6 \\
53 & \pm 4 \\
80 & \pm 6 \\
49 & \pm 4 \\
72 & \pm 4 \\
75 & \pm 4 \\
23 & \pm 4 \\
56 & \pm 2 \\
45 & \pm 3 \\
34 & \pm 4 \\
59 & \pm 14\end{aligned}$ & $\begin{array}{r}4 \\
4 \\
3 \\
4 \\
4 \\
4 \\
3 \\
4 \\
2 \\
4 \\
4 \\
4 \\
44\end{array}$ \\
\hline \multicolumn{4}{|l|}{ Bayo Canyon Stations } \\
\hline $\begin{array}{l}\text { Canyon floor } \\
\text { Mesa top (townsite) } 1 \\
\text { Mesa top (townsite) } 2 \\
\text { Group summary }\end{array}$ & $\begin{aligned} 37 & -61 \\
2 & -134 \\
4 & -77 \\
2 & -134\end{aligned}$ & $\begin{array}{l}45 \pm 5 \\
67 \pm 6 \\
43 \pm 4 \\
52 \pm 9\end{array}$ & $\begin{array}{r}4 \\
3 \\
3 \\
10\end{array}$ \\
\hline
\end{tabular}


TABLE XIII

EXTERNAL EXPOSURE

$(\mu R / h)$

\begin{tabular}{|c|c|c|}
\hline Background & Ion Chamber & GeLi \\
\hline $\begin{array}{l}\text { Mesa top } \\
(1.61 \mathrm{~km} S W \text { of Bayo Site })\end{array}$ & 22.9 & 23 \\
\hline $\begin{array}{l}\text { Mesa top } \\
(3.22 \mathrm{~km} w \text { of Bayo Site })\end{array}$ & 19.1 & 20.4 \\
\hline
\end{tabular}

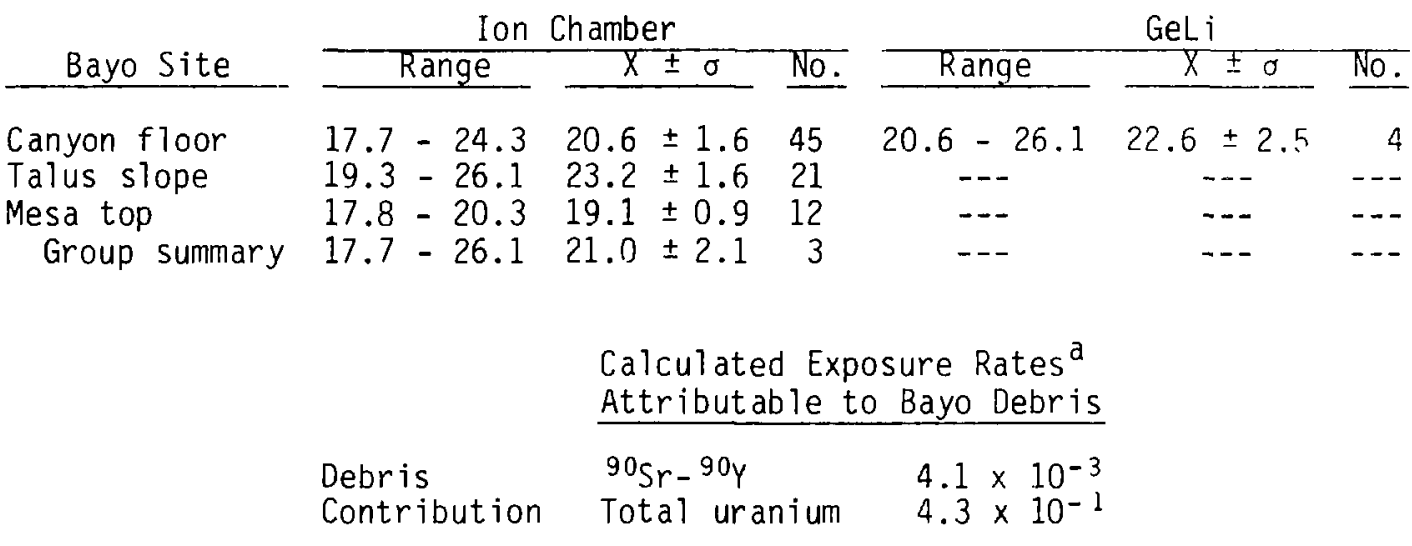

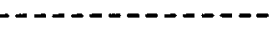

aDOE 77-24, Table B-8. 
4.7.3 Subsurface Soil Conditions (Below $30 \mathrm{~cm}$ ). Subsurface soil contamination is most Ty Tow Tevel and within $10 \mathrm{~m}$ of TA-10-1 and its acid waste system. The ${ }^{90} \mathrm{Sr}$ levels in the $30-$ to $122-\mathrm{cm}$ layer, obtained from 18 samples having high gross $B$ levels, had a mean concentration of $10.3 \mathrm{pCi} 90 \mathrm{Sr} / \mathrm{g}$ and a range of 0.1 to $67.2 \mathrm{pCi}$ ${ }^{90} \mathrm{Sr} / \mathrm{g}$. In all, 378 subsurface samples were taken from 30 to $200 \mathrm{~cm}$ and screened for gross $\beta$ activity, and of these, 68 were analyzed for ${ }^{90} \mathrm{Sr}$. Of these 68 samples, 12 exceeded $20 \mathrm{pCi} 90 \mathrm{sr} / \mathrm{g}$ and 8 exceeded $100 \mathrm{pCi}{ }^{0} \mathrm{Sr} / \mathrm{g}$. The maximum ${ }^{90} \mathrm{Sr}$ activity detected was $4310 \mathrm{pCi} / \mathrm{g}$, which was measured in a sample taken from the $460-$ to $600-\mathrm{cm}$ layer. The highest level sample contained $24000 \mathrm{pCi}$ gross $\mathrm{B} / \mathrm{g}$ and came from between 430 and $490 \mathrm{~cm}$ below the surface. The maximum gross $B$ sample at or above $244 \mathrm{~cm}$ was $4400 \mathrm{pCi} / \mathrm{g}$ at $244 \mathrm{~cm}$.

Soil sampling has indicated that soil concentrations of ${ }^{90} \mathrm{Sr}$ below 244-cm depth in a limited area around TA-10-1 exceed the cleanup criteria. Soil containing these levels would be removed under alternative 2. Uranium levels in subsurface soil were found to be at background concentrations.

Studies indicate that ground water has not been affected by the ${ }^{90} \mathrm{Sr}$ and uranium concentrations in Bayo Canyon. The runoff volume in the canyon is so low that there is no apparent water in the alluvium. The intermittent runoff is not a source of recharge to the main aquifer.

\subsection{ENVIRONMENTAL CONSEQUENCES}

5.1 Minimal Action Alternative (Alternative I)--Preferred Alternative

5.1.1 Radiological Consequences. There will be no cleanup under this atternative. The radiological risks and radiological conditions, as described in Sections 2.2 and 4.7 , respectively, will remain the same. However, the chance of exposure to the subsurface contamination will be effectively eliminated because of constraints placed on the use of the area where the subsurface contamination is locater.

5.1.2 Ecological Consequences. The ecological consequences associated with this alternative wil 1 be essentially zero. The placing of monuments to delineate the area of restricted use will involve some field work, but the associated ecological impact will be insignificant. No endangered species will be threatener. No alteration of the landscape will occur. No impact on the present natural succession of plant species will occur. There is no potential for surface or ground water contamination.

5.1.3 Land Use Impacts. Essentially, no 1 and use impacts are associated with this alternative. The removal of 0.6 hect are of 1 and from availability for residential development in the canyon is inconsequential. The restricted plot can be used for a playground, 
tennis court, park, or other recreational facility, and such a facility probably would be included in the plans for the canyon anyway. The most likely alternative to residential development will be continued use of the canyon for recreational purposes.

5.1.4 Socioeconomic Effects. No direct demographic, institutionaT, archaeological, or economic effects are associated with the minimal-action alternative. The placing of monuments and radiological surveillance can be carried out as part of the routine activities of County employees and Environmental Surveillance Group employees from the Los Alamos National Laboratory.

Because no actual cleanup is involved in this alternative, adverse public reaction could result from the perceived risk of surface contamination remaining in the canyon. The issue of contamination and debris could undergo considerable scrutiny with attendant publicity should the County decide to permit development of the land. Failure to implement any cleanup action could leave some question in the public mind as to the safety of developing the land for residential use.

5.1.5 Risk to Individual Health and Safety. Because little action is associated with this atternative, the direct risk resulting from its implementation is negligible. There remains, however, the potential for injury to the public from residual blast dibris, as discussed in Sections 2.2 and 4.7 .

\subsection{Decontamination and Restoration Alternative (Alternative II)}

5.2.1 Radiological Consequences. As only subsurface contamination above the working criteria will be removed, radiological risk and radiological conditions associated with surface contamination remain the same as described in Sections 2.2 and 4.7. The removal of the subsurface contamination eliminates the risk associated with its presence. This reduced risk, along with risks to cleanup workers, truck drivers, and in the event of an accident en route to the waste disposal site, is examined further in Section 5.2.5 on "Risk to Individual Health and Safety."

5.2.2 Ecological Consequences. Ford, Bacon \& Davis Utah has estimated that the removal of $1160 \mathrm{~m}^{3}$ of contaminated soil would require the removal and temporary storage of $12200 \mathrm{~m}^{3}$ of uncontaminated soil, which presently covers the contaminated material. Allowing for the backslope necessary to prevent cave-ins, $2790 \mathrm{~m}^{2}$ of surface area would be disturbed by the excavation itself, and another $4180 \mathrm{~m}^{2}$ would be required for stockpiling of uncontaminated soil. ${ }^{2}$ This represents a total of 0.7 hectare that would be disturbed by the cleanup action.

As noted in Section 4.6.1, the old TA-10 site, exclusive of the firing sites, supports the remnants of a ponderosa pine forest. These trees are estimated, on the basis of trunk diameter, to be 100 to 200 
yr old and, thus, are irreplaceable within one or two human lifetimes. They are a valuable natural asset to utilization of the land as a park, for a recreational area, or for residential development.

Because the old waste disposal area is located in the middle of this stand of trees, efforts should be made to arrange the backslope on the excavation pit so as to minimize damage to the trees. The uncontaminated cover material should be stockpiled to the west on the old firing sites, from which trees were removed during the period of site activity, so that damage to the ponderosa pine trees is minimized.

In Section 4.3, the soil was described as being reasonably fertile, so that revegetation should require little effort. However, the 0.7 hectare of land directly impacted by the excavation, plus other land incidentally disturbed, represents only a small fraction of the portion of the canyon bottom already disturbed both by the site operation and by the original decommissioning action. No effort was made after the decommissioning to rehabilitate the area, and thus, this section of the canyon is already in a state of natural succession. The firing sites, in particular, are still quite brushy and have not yet reverted to the grassland found elsewhere in the canyon. Revegetation of one small area in the midst of a larger disturbed area seems futile. Furthermore, if the canyon ultimately is to be used for residential development, as seems likely (Section 4.1.1), there is little point in a revegetation effort.

Although the portion of Bayo Canyon disturbed under this alternative is relatively small, a possibility exists that the area could contain some of the plants listed in Table VII as protected under New Mexico Statute 45-11 (Section 4.6.2.2). These plants, although protected by $1 \mathrm{aw}$, are not necessarily rare or endangered species. Thus, even if a small amount of damage to any of the species were to occur during the cleanup action, the consequences would be insignificant. However, any amount of damage would be sufficient for initiation of a lawsuit, if any person or organization were inclined to do so.

The peregrine falcons that nest in adjacent Pueblo Canyon have been observed to hunt in Bayo Canyon (Section 4.6.3.2). However, the falcons are known to range over a large part of Los Alamos County, and there is much open 1 and south of Pueblo Canyon on Los Alamos National Laboratory property. Therefore, the loss of Bayo Canyon as a hunting area should be inconsequential.

Noise associated with the excavation process (or with subsequent development of the canyon as a residential area) also is likely to have little effect on the falcons, because they already are tolerant of noise associated with the airport and industrial park located across Pueblo Canyon from the aerie.

The actual amount of contaminated soil that would require removal and disposition presently is estimated at about $1160 \mathrm{~m}^{3}$. This amount 
is an increase of 15 to $20 \%$ over the anticipated annual solid waste disposal at TA-54 for the next couple of years. Furthermore, if the Bayo Canyon cleanup occurrs within that time, it may be superimposed on additional disposal demands, such as an acid-sewer line cleanup and cleanup of two old burial sites. Thus, although the Bayo Canyon cleanup would not be unmanageable at the TA-54 operation, it would represent a significant increment and would place an additional strain on operations and on the limited burial space available. ${ }^{28}$

Eleven hundred and sixty cubic meters of clean fill to replace the excavated, contaminated soil probably can be removed from an existing borrow pit without undue impact. The inactive pit in Los Al amos Canyon (Section 4.1.4) does not appear to have been rehabilitated after previous use was terminated, so reactivation of the pit probably would not have a great effect on the environinent.

5.2.3 Land Use Impacts. As discussed in Section 4.1.1, the most probable future use of Bayo Canyon is for residential development. The impact of the decontamination alternative is that the additional 0.6hectare site of subsurface contamination would be available for unrestricted use. However, there is some question as to whether this area would be structurally suitable for resideritial construction because of the large volume of fill. Some period of time for compaction might be necessary before it could be so used.

The likelinood of increased potential for erosion is small, even though the area of excavation is on the floodplain of the intermittent stream that flows through Bayo Canyon, because of the small amount of runoff that normaily occurs. An extraordinarily large runoff event would be required to have a significant erosive effect. This conclusion is reinforced by noting ihat the firing sites, which were stripped of vegetation during site operation, do not show any signs of significant erosion.

5.2.4 Socioeconomic Effects. There are no direct demographic, institutionat, or archaeologica! effects associated with the decontamination and restoration alternative. As noted in Section 4.2.5, a recent search of the canyon located only one small archaeological site west of the Otowi Ruins, and this is not in the area that would be impacted by the excavation of the contaminated soil.

Economic effects associated with this alternative would be minimal. Ford, Bacon \& Davis Utah estimates that the required remedial action could be completed by a crew of 10 people in 55- to 65-working days at a total cost of $\$ 461,000 .{ }^{2}$ If the Zia Company, a private company under contract to DOE in LOS Alamos, were to undertake this cleanup, the operation would represent about $0.8 \%$ of their annual budget and less than $0.15 \%$ of total annual man hours for the company. Thus, regardless of whether Zia or some other company undertakes the cleanup, the economic impact on Los Alamos and the region will be insignificant. 
Transportation of contaminated soil to TA-54 should have a negligible impact on local traffic if it is not scheduled during peak commuter traffic hours.

5.2.5 Risk to Individual Health and Safety. The risks to mesatop residents, casual recreational users of the canyon, or permanent residents of the canyon from surface contamination remain as discussed in Section 2.2.

Because subsurface contamination in the area around TA-10-1 and its waste pits will be removed, potential radiation doses from exposure of hypothetical residential construction workers to ${ }^{90} \mathrm{Sr}$ levels elevated above the cleanup limit of $100 \mathrm{pCi} / \mathrm{g}$ would be reduced. This would principally affect individuals, involved in projects such as installing sewer lines, who are working at depths greater than 122 $\mathrm{cm}$. Estimates of maximum individual 50-yr dose commitments from inhalation would be reduced from $0.01 \mathrm{mrem}$ to at least $0.001 \mathrm{mrem}$ (to bone lining). The actual value would depend on how far below the 100 pCi $90 \mathrm{Sr} / \mathrm{g}$ limit the "as left" soil concentrations are.

Doses to cleanup workers and truck drivers carrying contaminated soil to TA-54, the waste disposal facility at the Laboratory, are summarized in Table XIV. The maximum 50-yr dose commitments to these two groups were estimated to be 0.10 and $0.89 \mathrm{mrem}$, respectively, to bone lining. These doses are 0.01 and $0.06 \%$ of the RPS to bone for members of the public. The doses were calculated using the same assumptions discussed in Section 2.2 for construction excavation at $2.4 \mathrm{~m}(8 \mathrm{ft})$ and an exposure time of $40 \mathrm{~h}$ per week for 12 weeks.

The risks associated with accidents during the cleanup process are small because of the small size of the operation, but some risk is associated with transport of contaminated soil to TA-54. The estimated $1160 \mathrm{~m}^{3}$ of soil to be removed from Bayo Canyon represents 200 to 250 truckloads of material, which will be hauled from Bayo Canyon to TA-54 (Fig. 5). Based on Interstate Commerce Commission statistics of $5.24 \times 10^{-8}$ accidents per ton-mile and $5.14 \times 10^{-9}$ fatalities per ton-mile, ${ }^{29}$ there is a 0.0016 probability of an accident and a 0.00015 probability of a fatality occurring during the course of the soil transportation.

In the unlikely event of an accident, the soil transported by truck may spill in a place, such as the vicinity of the community of White Rock, where there is potential for some radiation exposure to the public. Inhalation of material resuspended by wind would be the principal exposure route. A maximum 50-yr dose commitment to persons near the accident was evaluated and found to be $0.02 \mathrm{mrem}$ to the bone, $0.001 \%$ of the RPS.

Doses are summarized in Table XIV. Details of the dose calculations are given in Appendix B. 
TABLE XIV

DOSE EVALUATION FOR BAYO CANYON CLEANUP

Group Receiving

Estimated Dose

Contributing

Soil Depth Dose (mrem) ${ }^{\mathrm{a}}$ Red

$(\mathrm{cm})$ Bone Lung Marrow

Decontamination worker ${ }^{b}$

Inhalation

External dose

Total ${ }^{e}$

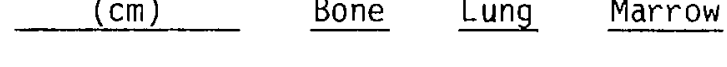

122 to 244

$0.08<0.01$

0.07

122 to 244

$\frac{0.02}{0.10} \quad \frac{0.02}{0.02} \quad \frac{0.02}{0.09}$

Truck Drivers ${ }^{c}$

Inhalation

External dose

Totale

\begin{tabular}{lll}
0.04 & $<0.01$ & 0.03 \\
0.85 & $\frac{0.85}{0.85}$ & 0.85 \\
\hline 0.89 & 0.88
\end{tabular}

Maximally exposed

$0.02<0.01 \quad 0.01$

member of public

due to accident

$\begin{array}{llll}\text { Radiation Protection } & 1500 & 1500 & 500 \\ \text { Standard }\end{array}$

Per cent of RPS

(worst case)

Internal doses are 50-yr dose commitments.

$b_{\text {Based on }} 480-h$ exposure.

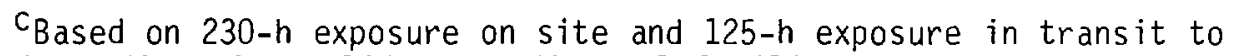
the radioactive solid waste disposal facility.

dTaken from Ref. 4.

esummation of internal plus external doses. 


\subsection{No-Action Alternative (Alternative III)}

5.3.1 Radiological Consequences. If no cleanup of any type is undertaken, the radiological risks and conditions will remain the same as discussed in Sections 2.2 and 4.7.

5.3.2 Ecological Consequences. The ecological consequences of this action are zero. No endangered species will be threatened; no alteration of the landscape will occur; and no impact on the present natural succession of plant species will occur. No potential for surface or ground water contamination exists. Conditions will remain as described in Sections 4.3 and 4.6.

5.3.3 Land Use Impacts. Failure to implement any cleanup action very likely will have little impact on the decision to go ahead with residential development of Bayo Canyon. Developable 1 and is scarce in Los $A 7$ amos County (Section 4.2.1), and so, because the State has concurred that the residual surface contamination remaining poses no significant health hazard (Section 2.2), residential development probably will occur under any circumstances. Should residential development not occur, the most likely alternative is continued use of the canyon for recreational purposes (hiking, Boy Scouts, skeet shooting, horseback riding, etc.).

5.3.4 Socioeconomic Effects. No direct demographic, economic, institutionat, archaeological, or other socioeconomic factors will be affected under the no-action alternative. Such effects will occur secondarily if subsequent residential development occurs. However, the fate of the site will be decided by the owner, Los Alamos County, and actions taken at the site will be beyond control of the DOE.

Failure to implement any remedial action in Bayo Canyon will undoubtedly leave some question in the public mind as to the safety of developing the 1 and for residential use. Residual contamination and debris could conceivably become an issue should the County decide to permit development of the 1 and.

\subsubsection{Risk to Individual Health and Safety. There will be no} human risk from remedial actions, because no action occurs. Risks to recreational users, residents, or construction workers will remain as discussed in Section 2.2.

\section{REFERENCES}

1. Los Alamos Scientific Laboratory, "Radiological Survey of the Bayo Canyon, Los Alamos, New Mexico," Department of Energy report DOE/EV-0005/15 (June 1979).

2. Ford, Bacon \& Davis Utah Inc., "Engineering Evaluation of the Bayo Canyon Site, Los Al amos, New Mexico," Bechtel report OR1/044/01 (September 1981). 
3. New Mexico State Environmental Improvement Division letter from Thomas E. Buhl, Environmental Program Manager, Radiation Protection Section, to Pat Brown, Planning Director, Incorporated County of Los Alamos, New Mexico (December 16, 1979).

4. US Department of Energy, "Environmental Protection, Safety, and Health Protection Programs for DOE Operations; Requirements for Radiation Protection," US DOE Manual 5480.1, Chapter XI (1981).

5. International Commission on Radiological Protection, Annals of the ICRP, Publication 26, Vol. 1, No. 3 (Pergamon Press, New York, 1977).

6. National Council on Radiation Protection and Measurements, "Natural Background Radiation in the United States," NCRP Report 45 (1975).

7. J. W. Healy, J. C. Rodgers, and C. L. Wienke, "Interim Soil Limits for D\&D Projects," Los Alamos Scientific Laboratory report LA-UR-79-1865-Rev. (September 12, 1979).

8. National Council on Radiation Protection and Measurements, "Basic Radiation Protection Criteria," NCRP report 39 (1971).

9. Los Alamos County Council letter from Roger W. Taylor, Chairman, to William Crismon, Jr., Chief, Technical Programs Branch, Los Alamos Area Office, Department of Energy (January 12, 1982).

10. Health Division, "Waste Disposal," Los Alanos Scientific Laboratory Health, Safety and Environment Manual, Chapter 1, Section 7 (October 1979).

11. M. A. Rogers, "History and Environmental Setting of LASL NearSurface Land Disposal Facilities for Radioactive Wastes (Areas A, $B, C, D, E, F, G$, and T)," LoS Alamos Scientific Laboratory report LA-6848-MS, Vol. I (June 1977).

12. Environmental Surveillance Group, "Environmental Surveillance at Los Al amos During 1980," Los Al amos National Laboratory report LA-8810-ENV (April 1981).

13. Los Alamos Scientific Laboratory, "Final Environmental Impact Statement," Department of Energy report DOE/EIS-0018 (December 1979).

14. W. D. Purtymun and M. N. Maes, "Water Supply at Los Alamos During 1980," Los Alamos National Laboratory report LA-8977-PR (October 1981).

15. Los Alamos National Laboratory internal memorandum from Charlie R. Steen, Archaeological Consultant, to Roger W. Ferenbaugh, 
Environmental Surveillance Group, "Archaeologica Sites in Bayo Canyon," (June 23, 1981).

16. Los Alamos National Laboratory internal memorandum from Charlie R. Steen, Archaeological Consultant, to Roger W. Ferenbaugh, Environmental Surveillance Group, "Archaeological Sites in Bayo Canyon," (July 9, 1981).

17. Charlie R. Steen, "Pajarito Plateau Archaeological Survey and Excavations," LoS Alamos Scientific Laboratory report LASL-77-4 (May 1977).

18. Department of Energy, LoS Alamos Area Office letter from Gary.M. Granere, Acting Area Manager, to the Keeper of the National Register of Historic Piaces, National Park Service (June 11, 1981).

19. New Mexico State University, Department of Agronomy, letter from Bruce Buchanan, Assistant Professor of Agronomy, to Roger W. Ferenbaugh, Environmental Surveillance Group, Los Alamos Scientific Laboratory (May 29, 1980). (See Appendix A.)

20. J. W. Nyhan, L. W. Hacker, T. E. Calhoun, and D. L. Young, "Soil Survey of Los Alamos County, New Mexico," Los Al amos Scientific Laboratory report LA-6779-MS (June 1978).

21. Los Alamos National Laboratory internal memorandum from Roger $W$. Ferenbaugh, Environmental Surveillance Group, to Harry S. Jordan, Associate H-Division Leader, "Air Quality Regulation Review-Summary," (May 7, 1981).

22. 40 CFR 81.421 .

23. T. S. Foxx and G. D. Ti srney, "Treatment of the Emergency Landing Strip in Pueblo Canyon aid Its Relationship to the Peregrine Falcon Habitat," Los Alamos National Laboratory report (in press).

24. T. S. Foxx and G. D. Tierney, "Status of the Flora of the Los Alamos National Environmental Research Park," Los Al amos Scientific Laboratory report LA-8050-NERP, Vol. I (May 1980).

25. F. R. Miera, Jr., K. V. Bostick, T. E. Hakonson, and J. W. Nyhan, "Biotic Survey of Los Alamos Radioactive Liquid-Effluent Receiving Areas," Los Alamos Scientific Laboratory report LA6503-MS (January 1977).

26. A. G. Journel and C. J. Huijbregts, Mining Geostatistics (Academic Press, New York, 1978).

27. W. C. Courtright, "TA-10 Bayo Canyon Cleanup," Los Alamos Scientific Laboratory report LAMS-2945 (October 1963). 
28. Los Alamos National Laboratory internal memorandum from John $L$. Warren, Associate H-7 Group Leader for Disposal, to Roger W. Ferenbaugh, Environmental Surveillance Group, "FUSRAP and Bayo Canyon," (November 2, 1981).

29. Department of Transportation, "Tenth Annual Report," US Government Printing Office (1977). 
APPENDIX A

BAYO CANYON SOIL. FERTILITY DATA 
May 29, 1980

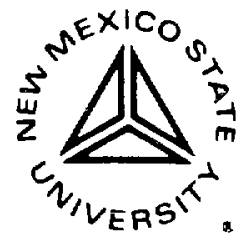

Dr. Roger W. Ferenbaugh

Group H-8, MS 490

Environmental Surveillance

Los Alamos Scientific Laboratory

P. 0. Box 1663

Los Alamos, New Mexico 87545

Dear Roger:

Enclosed are the results of the soil analysis. Listed below are approximate levels indicating fertility level from the Colorado Extension publication reference included.

Nitrogen less than 1 ppm add 50 lbs/acre unless manure (o.m.) is added then reduce amount of $\mathrm{N}$.

Potassium anything greater than $60 \mathrm{ppm}$ is high - $\mathrm{K}$ is not needed - could add $40 \mathrm{lbs} /$ acre as a starter.

Phosphorus $0-7 \mathrm{ppm}$ add 40 lbs/acre $\mathrm{P}_{2} \mathrm{O}_{5}$

8-.24 ppm add $20 \mathrm{lbs} / \mathrm{acre} \mathrm{P}_{2} \mathrm{O}_{5}$ and would plan on adding $40 \mathrm{lbs} / \mathrm{acre}$.

Iron greater $4.0 \mathrm{ppm}$ is adequate - if $\mathrm{Fe}$ is added it would be best to add foliar - but it isn't going to be necessary. Note control.

Manganese greater $1.0 \mathrm{ppm}$ is adequate - note control is fairly high but it is not toxic at these $\mathrm{pH}$ values.

Copper greater than $0.2 \mathrm{ppm}$ is adequate. The middle $0-6$ is high but copper additions are not needed nor should they be toxic.

Zinc greater than $0.25 \mathrm{ppm}$ is adequate - Zn levels are fine.

Texline is easy to work; one would expect good drainage, minimum crusting actually couldn't be better. The salts are very low, Ca-Mg ratios are good and SAR is very low. SAR of 4 begins to limit some plants. The $\mathrm{pH}$ is just about ideal. I would like the organic matter to be erased some by either adding manure or straw and nitrogen. Add about 10 tons/acre manure.

The Colorado publication is listed below. If you have trouble getting a copy, I could xerox our copy for you. It should be available from Colorado State. 
Guide to Fertilizer Recommendations in Colorado, Soil Analysis and Computer Process. Cooperative Extension Service Colorado State. Jan. 1978. P.N. Soltanpour, A. Ludwick, and J. O. Reuss.

Let me know if you need anything concerning these, and send the bill to the person on the purchase request, Charles Justis.

Sincerely,

Bunce- Buchionary

Bruce Buchanan

Assistant Professor

BD: muc

Enclosure

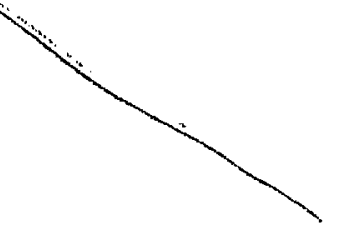


COLLEGE OF AGRICULTURE ANO HOME ECONOMICS

DEPARTMENT OF AGRONOMY

Box 30/Las Cruces. New Mexico 88003

Telephone (505) 646.3405

May 9, 1980

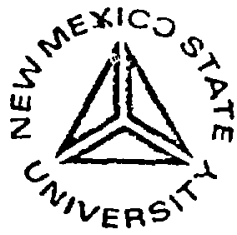

To: Univ. of lial. at Los Alamos

Charles Justis Lpll

P.0. Box 990 Mail stop 274

Los Alamos, NM 87544

From: Soil \& Hater Testing Lab.

NMSU BOX 3Q

Las Cruces, NM 88003

Subject: Soil analysis to be interpreted by Or. Buchanan

\begin{tabular}{|c|c|c|c|c|c|c|c|c|c|c|}
\hline Sample & $\begin{array}{c}\text { mmhos } / \mathrm{cm} \\
\text { E.C. }\end{array}$ & $\mathrm{pH}$ & $\mathrm{Na}$ & $\begin{array}{c}\mathrm{meq} / \mathrm{L} \\
\mathrm{Ca} \\
\end{array}$ & Mg & SAR & $\begin{array}{l}\% \\
011\end{array}$ & $\begin{array}{l}1: 5 \\
\mathrm{NO}_{3}\end{array}$ & $\begin{array}{c}\mathrm{HH}_{4} \mathrm{ppm} \\
\mathrm{K}\end{array}$ & $\begin{array}{c}\mathrm{NaHCO}_{3} \\
\mathrm{P}\end{array}$ \\
\hline $\begin{array}{l}\text { Control } 0-6 \\
\text { Lower } 12-18 \\
\text { Haste } 12-18 \\
\text { South } 0-6 \\
\text { Middle } 0-6 \\
\text { Waste } 0-6 \\
\text { Lower } 0-6 \\
\text { South 12-18 } \\
\text { Middle 12-18 }\end{array}$ & $\begin{array}{l}.159 \\
.266 \\
.386 \\
.165 \\
.249 \\
.261 \\
.248 \\
.268 \\
.411\end{array}$ & $\begin{array}{l}6.79 \\
6.80 \\
7.79 \\
7.13 \\
6.97 \\
7.51 \\
7.02 \\
6.84 \\
7.07\end{array}$ & $\begin{array}{l}.21 \\
.72 \\
.46 \\
.17 \\
.19 \\
.35 \\
.42 \\
.51 \\
1.34\end{array}$ & $\begin{array}{l}.81 \\
1.00 \\
2.45 \\
.80 \\
1.25 \\
1.55 \\
1.11 \\
1.09 \\
1.37\end{array}$ & $\begin{array}{l}.23 \\
.36 \\
.59 \\
.22 \\
.18 \\
.38 \\
.35 \\
.33 \\
.45\end{array}$ & $\begin{array}{l}.29 \\
.87 \\
.37 \\
.24 \\
.22 \\
.36 \\
.49 \\
.60 \\
1.40\end{array}$ & $\begin{array}{r}1.39 \\
.81 \\
.48 \\
1.50 \\
1.24 \\
.48 \\
.98 \\
.29 \\
.77\end{array}$ & $\begin{array}{r}3.40 \\
1.05 \\
.55 \\
1.20 \\
.35 \\
.65 \\
2.65 \\
2.50 \\
2.15\end{array}$ & $\begin{array}{r}168 \\
156 \\
123 \\
143 \\
268 \\
158 \\
113 \\
94 \\
232\end{array}$ & $\begin{array}{r}6.6 \\
10.0 \\
2.6 \\
15.0 \\
13.4 \\
5.8 \\
10.6 \\
4.0 \\
4.0\end{array}$ \\
\hline
\end{tabular}

$\begin{array}{lrrrrrrrl}\text { Control 0-6 } & 10.06 & 11.92 & .36 & .96 & 62.8 & 26.6 & 10.6 & \text { Sandy loam } \\ \text { Lower 12-18 } & 4.40 & 6.32 & .56 & .80 & 72.8 & 18.4 & 8.8 & \text { Sandy loam } \\ \text { Waste 12-18 } & 1.68 & 1.68 & .14 & .16 & 61.0 & 28.2 & 10.8 & \text { Sandy loam } \\ \text { South 0-6 } & 8.36 & 9.34 & 9.38 & 4.20 & 64.8 & 24.6 & 10.6 & \text { Sandy loam } \\ \text { Middle 0-6 } & 7.06 & 16.58 & 15.12 & 4.38 & 50.4 & 32.8 & 16.8 & \text { Loam } \\ \text { Haste 0-6 } & 3.20 & 4.86 & .42 & .68 & 59.0 & 28.4 & 12.6 & \text { Sandy loam } \\ \text { Lower 0-6 } & 6.46 & 6.38 & .98 & 1.48 & 68.4 & 22.8 & 8.8 & \text { Sandy loam } \\ \text { South 12-18 } & 5.24 & 6.52 & 1.16 & .58 & 56.8 & 30.6 & 12.6 & \text { Sandy loam } \\ \text { Hiddle 12-18 } & 4.82 & 4.74 & 2.22 & 1.12 & 44.8 & 36.6 & 18.6 & \text { Loam }\end{array}$




\section{APPENDIX B}

\section{DOSE CALCULATION PROCEDURES}

Recommendations in this report incorporate assessments of the radiation risk to members of the public caused by residual radioactive contamination in Bayo Canyon. In this appendix, an outline of the dose calculation procedures is presented, from which the soil limits were derived, and on which these risk estimates are based. The outline follows the methodology used by Healy, Rodgers, and Wienke ${ }^{l}$ in deriving the soil limits. Refer to Ref. 1 for a more detailed description of their procedures and underlying rationale.

Results of pathway analysis are given in the second section of this appendix. Radiation doses resulting from measured ${ }^{90} \mathrm{Sr}$ and uranium soil concentrations in Bayo Canyon are evaluated for scenarios corresponding to different uses of the contaminated area.

\subsection{DERIVATION OF SOIL LIMITS}

Interim limits for natural uranium and ${ }^{90} \mathrm{Sr}$ were calculated by Healy, Rodgers, and Wienkel so that no individual would receive any organ dose during any year in a 70-yr lifetime greater than 0.5 rem. This dose limit is based on the recommendations of the National Council on Radiation Protection and Measurement (NCRP). ${ }^{2}$ Assumptions tending to maximize the dose from soii contamination were used throughout the calculations to assure that the dose limits would not be exceeded. Three exposure pathways, inhalation and ingestion of contaminated material and external radiation, were evaluated in deriving these limits.

Annual dose rates for lung and bone were calculated for inhalation of $238_{\mathrm{U}}-{ }^{23} \mathrm{U}$, and annual dose rates to bone were calculated for inhalation of ${ }^{90} \mathrm{Sr}$ and ingestion of $238 \mathrm{U}-{ }^{234} \mathrm{U}$ and ${ }^{90} \mathrm{Sr}$, per unit intake of activity during a 70-yr lifetime of continuous exposure.

In calculating these dose rates, contributions from intake of the uranium decay products $234 \mathrm{mPa},{ }^{23}{ }^{4} \mathrm{~Pa}$, and ${ }^{23}{ }^{4} \mathrm{Th}$ and from intake of the ${ }^{90} \mathrm{Sr}$ decay product $90 \mathrm{y}$ were negligible. Calculations for doses from intake of these radionuclides are not presented. Doses from these radionuclides are included in the dose calculations if the radionuclides are produced inside the body from decay of the parent. The contribution from the intake of $234 \mathrm{U}$ with $238 \mathrm{U}$ is included.

The inhalation dose calculation was based on the Task Group Lung Model of the International Commission on Radiological Protection (ICRP).3,4 Parameters used for the calculation are summarized in Table B-I, adapted from Ref. 1. They include the use of $Y$ and $W$ solubility classifications for uranium and strontium, respectively, and an activity medium aerodynamic diameter of $1 \mathrm{~lm}$.

Dose estimates due to ${ }^{90} \mathrm{Sr}$ intakes are based on ${ }^{90} \mathrm{Sr} / \mathrm{calcium}$ ratios. For ${ }^{0} \mathrm{Sr}, 30 \%$ of the inhaled material that reaches the 
PARAMETERS USED IN CALCULATION OF DOSE RATE FACTORS

\begin{tabular}{|c|c|c|}
\hline & $238 \mathrm{U}-234 \mathrm{U}$ & Strontium \\
\hline Solubility class & Y & $W$ \\
\hline Activity median aerodynamic diameter & $1 \mu \mathrm{m}$ & $1 \mu \mathrm{m}$ \\
\hline \multicolumn{3}{|l|}{ Biological half-life } \\
\hline Lung & 400 days & 90 days \\
\hline Bone & 500 days & \\
\hline \multicolumn{3}{|l|}{ Organ transfers } \\
\hline Nasopharyngeal to blood & 0.01 & 0.10 \\
\hline Tracheobronchial to blood & 0.01 & 0.10 \\
\hline Pulmonary to blood & 0.05 & 0.15 \\
\hline Pulmonary to $1 \mathrm{ymph}$ & 0.15 & 0.05 \\
\hline Lymph to blood & 0.9 & 1.0 \\
\hline GI to blood & 0.2 & 0.3 \\
\hline Blood to bone & 0.20 & \\
\hline \multicolumn{3}{|l|}{ Radiological Factors } \\
\hline Quality factor & 10 & \\
\hline Dose distribution factor & $5(U$ only) & \\
\hline \multicolumn{3}{|c|}{ Alpha energy deposited in organ per disintegration } \\
\hline Lung & $8.96 \mathrm{MeV}$ & \\
\hline Bone & $8.96 \mathrm{MeV}$ & \\
\hline \multicolumn{3}{|l|}{ Organ mass } \\
\hline Lung & $1000 \mathrm{~g}$ & \\
\hline Bone & $5000 \mathrm{~g}$ & \\
\hline
\end{tabular}


gastrointestinal (GI) tract is absorbed by the blood. The assumption is that the $90 \mathrm{Sr}$ absorbed through either the lung or GI tract mixes with the daily calcium intakes, and that $90 \mathrm{Sr} / \mathrm{calcium}$ in bone is 0.14 of that in blood. Dose conversion factors of $1.4 \mathrm{mrad} / \mathrm{yr} \mathrm{per} \mathrm{pCi}$ ${ }^{90} \mathrm{Sr} / \mathrm{g}$ calcium to the bone marrow and $1.9 \mathrm{mrad} / \mathrm{yr}$ per $\mathrm{pCi} 90 \mathrm{Sr} / \mathrm{g}$ calcium to the bone surface were used.

In calculating dose rate to bone for inhalation and ingestion of uranium, uranium absorption in the GI tract was conservatively set at $20 \% .1$ The authors felt that this value, although probably overestimating the dose, provided a reasonable upper limit on dose rate until the question of gut uptake of uranium is resolved.

Annual dose rates corresponding to constant radionuclide intake of $23 \mathrm{pCi} / \mathrm{day}$ (inhalation) and $1 \mathrm{pCi} /$ day (ingestion) over a 70-yr lifetime were calculated using these parameters. The only exception was for ingestion of ${ }^{90} \mathrm{Sr}$, for which the dose was calculated in terms of the $90 \mathrm{Sr} / \mathrm{calcium}$ ratio in the diet. In Table B-II (taken from Ref. 1), the annual doses are listed for select years for both ingestion and inhalation.

Inhalation exposure was estimated using a mass loading approach, based on the amount of respirable dust in the air. The maximally exposed individual was assumed to spend $100 \%$ of his time in the contaminated area for $70 \mathrm{yr}$. For $8 \mathrm{~h} /$ day, 5 days/week, he would work outdoors, during which time he would inhale one-half of his total daily air intake of $23 \mathrm{~m}^{3}$ and be exposed to dust levels of $400 \mathrm{\mu g} / \mathrm{m}^{3}$. For $10 \mathrm{~h} / \mathrm{day}, 7$ days/week, he would be inside where dust levels are 50 $\mu \mathrm{g} / \mathrm{m}^{3}$. The remaining time would be spent outdoors under ambient dust loading of $100 \mu \mathrm{g} / \mathrm{m}^{3}$. The weighted average air concentration, taking into account time spent under each condition and breathing rates, would be $200 \mathrm{\mu g} / \mathrm{m}^{3}$.

Given this dust loading, a standard breathing rate of $23 \mathrm{~m}^{3}$ day, and the dose rates per amount inhaled described above, the soil concentration corresponding to the $0.5 \mathrm{rem} / \mathrm{yr}$ dose limit was calculated for the inhalation pathway.

Consumption of food grown in soil containing above-background $238 \mathrm{U}-234 \mathrm{U}$ and ${ }^{90} \mathrm{Sr}$ was considered to be the most important ingestion pathway. Estimates were developed for the home gardener diet; the gardener would grow one-third of his fruit and one-half of his vegetables, totaling some $80 \mathrm{~kg}$ of $\mathrm{plant-derived} \mathrm{foods} \mathrm{each} \mathrm{year.}$

A uranium concentration ratio, which is the uranium activity ( $p C i) /$ wet weight of food $(g)$, per uranium activity ( $p C i) / d r y$ weight of soil $(g)$ of $1 \times 10^{-3}$ was used to relate uranium concentration in plants to soil contamination. Uranium intake per unit soil concentration was calculated from the home gardener vegetable and fruit consumption rate and the uranium concentrations in plants. In a final step, the uranium intake and the derived ingestion dose rates were used to estimate the dose per unit uranium activity in soil and the soil concentration that corresponded to the $0.5 \mathrm{rem} / \mathrm{yr}$ dose limit for the ingestion pathway. 
TABLE B-I I

DOSE RATES (rems/yr) AND TOTAL DOSES (rems) FROM: ${ }^{a}$

1. Inhalation of $23 \mathrm{pCi} /$ day $\left(1 \mathrm{pCi} / \mathrm{m}^{3}\right)$

Time (yr)

5

50

70

Total (rem)

$\frac{238 U-234 U}{\text { Lung Bone }}$

3.1

0.27

3.3

0.62

3.3

0.62

230

2. ingestion of $1 \mathrm{pCi} / \mathrm{day}$

\section{Time $(y r)$}

5

50

70

Total $\frac{238 U-234 U}{\text { Bone }}$

0.044

0.048

0.048

3.3

adopted from Ref. 1. 
The ${ }^{90} \mathrm{Sr}$ soil limit ingestion pathway was derived by estimating the ${ }^{90} \mathrm{Sr} / \mathrm{calcium}$ ratio in plants due to surface ${ }^{90} \mathrm{Sr}$ contamination and the consequent ${ }^{90} \mathrm{Sr} / \mathrm{calcium}$ ratio in bone from consumption of the plants. This allowed calculation of the expected bone dose and also the soil concentration giving a $0.5 \mathrm{rem} / \mathrm{yr}$ dose.

External radiation from ${ }^{238} \mathrm{U}$ also was based on $100 \%$ occupancy of the contaminated area. Radiation from ${ }^{90} \mathrm{Sr}-90 \mathrm{Y}$, primarily $\mathrm{B}$ radiation emitters whose critical organ would be skin, was not considered.

For both ${ }^{90} \mathrm{Sr}-90 \mathrm{Y}$ and $238 \mathrm{U}-234 \mathrm{U}$, the ingestion pathway was the most limiting. The final soil limit for each radionuclide was calculated from the inverse of the sum of the reciprocals of the limit for the inhalation, ingestion, and external radiation pathways.

In deriving these limits, ${ }^{238} \mathrm{U}$ was assumed to be in equilibrium with its decay products, ${ }^{234} \mathrm{Th},{ }^{234} \mathrm{~Pa}$, and ${ }^{234} \mathrm{U}$. Equilibrium between $238 \mathrm{U}$ and its decay products is characteristic of natural uranium. In depleted uranium, which comprises some $60 \%$ of the uranium released at the Bayo Canyon site, $234 \mathrm{U}$ is in approximately $50 \%$ equilibrium with $238 \mathrm{U}$. The ${ }^{234} \mathrm{U}-238 \mathrm{U}$ activity ratio, taking into account both the natural and depleted uranium released at the site, is $63 \%$. Use of the $40-\mathrm{pCi} 238 \mathrm{U} / \mathrm{g}$ limit for Bayo Canyon should be additionally protective of public health because it assumes more ${ }^{234} \mathrm{U}$ to be present than is actually there.

No crerrection was made in the derivation of the soil criteria for the decay of ${ }^{90} \mathrm{Sr}$. Because the ${ }^{90} \mathrm{Sr}$ radioactive half-life is $28 \mathrm{yr}$, the ${ }^{90} \mathrm{Sr}$ soil levels would decay to $18 \%$ of their original value during the 70-yr exposure time. Not taking into account the $90 \mathrm{Sr}$ decay is a conservative procedure because the estimated maximum annual dose would be less than the $0.5-r e m ~ l i m i t$ for the $100-p C i{ }^{90} \mathrm{Sr} / g$ soil criteria.

\subsection{CALCULATION OF RADIATION DOSES}

Doses are estimated for three activity categories: permanent residence in Bayo Canyon, construction activities involving working with the contaminated soil, and cleaning up the residual contamination. The first two categories would typify maximum doses under the no-action alternative, whereas the third would set an upper limit on doses to workers and members of the public if cleanup were to occur. Where applicable, doses were estimated using the procedures taken from Ref. 1, discussed above.

The largest calculated doses correspond to the development of Bayo Canyon as a residential area. This would involve year-long occupancy of the canyon by members of the public and some use of the canyon for gardening. Doses estimated for these activities would be larger than those incurred by $t$ ie occasional users of canyon facilities, such as hikers or horseback riders. The doses calculated for full-time residence in the canyon are presented here as indicative of the maximum exposures to members of the public under the no-action alternative. 
Some organ doses resulting from exposure to $90 \mathrm{Sr}$ and uranium, such as those to bone, occur over relatively long time periods after the exposure because these radionuclides are only slowly removed from those organs. Depending on the situation, this extended exposure period is accounted for in one of two ways in this dose assessment:

1. the use of the maximum annual dose occurring for any year during a 70-yr lifetime of continuous exposure at constant levels; or

2. the use of the 50-yr dose commitment, which is the total dose received by an organ during the $50 \mathrm{yr}$ following the exposure.

Maximum annual doses during a 70-yr exposure are calculated from the dose rate factors given in Table B-II. The 50-yr dose commitments for a given intake of ${ }^{90} \mathrm{Sr}$ or uranium are derived from the $50-\mathrm{yr}$ dose commitment conversion factors (OCFs) presented in Table B-III.

These DCFs were calculated from Healy et al., l using the fact that the dose rate for the 50th yr of continuous exposure to an annual intake of $1 \mathrm{\mu C} i$ is equal to the 50-yr dose commitment due to a single intake of $1 \mathrm{\mu Ci} .5$ The dose rates at 50 years were calculated by Healy et al. for continuous intake of $23 \mathrm{pCi} /$ day (inhalation) and $1 \mathrm{pCi} / \mathrm{day}$ (ingestion). The annual intake was found for inhalation and ingestion, and the DCFs derived by dividing the 50-yr dose by the annual intake.

Dose in bone was calculated as dose to the bone lining cells. This involved modifying the $238 \mathrm{U}$ and $234 \mathrm{U}$ dose factors. The dose factors for uranium were calculated through use of $S$ factors from Dunning et al. 6 The $S$ factors used here, S(bone lining from bone) and $S$ (bone from bone), give the dose in the bone lining cells and bone, respectively, per $\mu \mathrm{C} \mathbf{i}$-day of uranium deposited in bone. The uranium dose rate and 50-yr dose commitment factors for bone were multiplied by the ratio of the $S$ factors, S(bone lining from bone)/S(bone from bone). These ratios are 0.0806 and 0.0889 for $238 \mathrm{U}$ and $234 \mathrm{U}$.

For the inhalation and ingestion pathways for potential residents, the maximum annual dose for a 70-yr continuous exposure is calculated because lifelong occupation of the contaminated area is involved. "For other situations, in which the exposures are of shorter duration, the 50-yr dose commitment is used because this is more representative of the exposure situation.

Soil concentrations used in the dose calculations are taken from the radiological survey results. ${ }^{7}$ Complete equilibrium was assumed between ${ }^{90} \mathrm{Sr}$ and $90 \mathrm{Y}$, and $63 \%$ equilibrium between $238 \mathrm{U}$ and ${ }^{23}{ }^{4} \mathrm{~J}$. However, as in Section B.1, doses from intake of $90 \mathrm{Y},{ }^{234} \mathrm{Th},{ }^{234} \mathrm{~Pa}$, and $234 \mathrm{mpa}$ were negligible. 


\section{TABLE B-III}

\section{CONVERSION FACTORS USED IN CALCULATING RADIATION DOSE}

Maximum Annual Dose in 70-Yr Exposure [rem/( $\mu \mathrm{Ci} / \mathrm{yr})$ intake]

Mode of Exposure

\begin{tabular}{|c|c|c|}
\hline Inhalation & Lung & Bone Lining \\
\hline $238_{U}$ & 183.6 & 2.85 \\
\hline $234 U$ & 209.2 & 3.42 \\
\hline${ }^{90} \mathrm{Sr}$ & & 0.155 \\
\hline
\end{tabular}

Ingestion

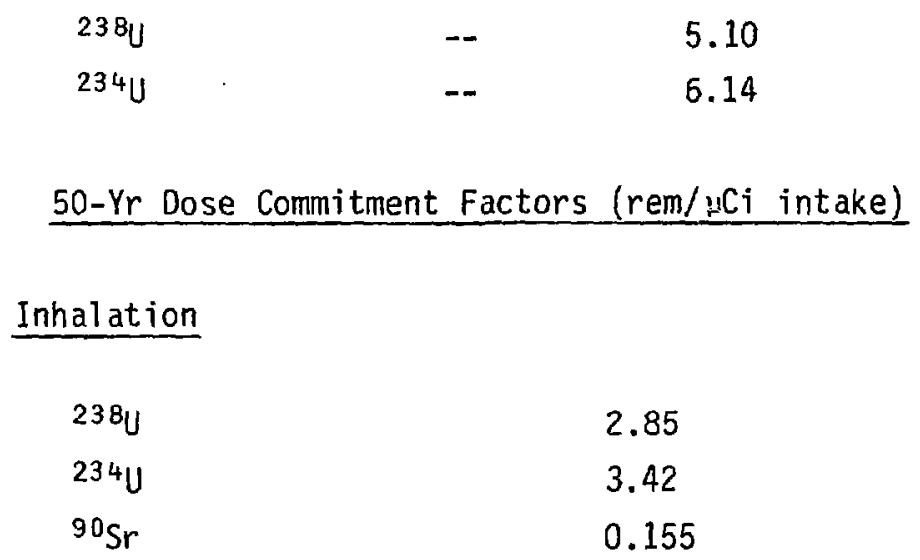




\subsection{Inhalation of Contaminated Soil (0- to $5-\mathrm{cm}$ soil layer)}

Inhalation of resuspended surface contamination could result in radiation doses, principally to the lungs and bone. The abovebackground ${ }^{90} \mathrm{Sr}$ and ${ }^{238} \mathrm{U}-234 \mathrm{U}$ concentrations in the $0-$ to $5-\mathrm{cm}$ soil layer, from Table B-III, are multiplied by $200 \mathrm{\mu g} / \mathrm{m}^{3}$ to obtain the radionuclide air concentrations, by $8395 \mathrm{~m}^{3} / \mathrm{yr}$ to get the annual intake of each radionuclide, and by the 70-yr conversion factors to obtain the dose.

The calculated doses (Tabie B-II) are the maximum annual doses during $70 \mathrm{yr}$ of exposure to these air concentrations. The calculations assume 100\% occupancy of the contaminated area throughout the year.

\subsection{Ingestion of Homegrown Produce (0- to $30-\mathrm{cm}$ soil layer)}

Vegetables and fruits grown in residential areas developed in Bayo Canyon may absorb residual ${ }^{90} \mathrm{Sr}$ and $238 \mathrm{U}-234 \mathrm{U}$ from the soil, resulting in a dose to man. Following Healy, et al., l the assumption was made that a home garden would supply $80 \mathrm{~kg} / \mathrm{yr}$ of vegetables and fruits to the maximum exposed individual. The $0-$ to $30-\mathrm{cm}$ soil concentration results were used in the calculations because this soil depth is representative of root zones of many garden plants.

Uranium. From the concentration ratio of $1 \times 10^{-3}$ and the uranium soil concentrations, the activity of each uranium isotope per plant wet weight was determined. Multiplication by $80 \mathrm{~kg} / \mathrm{yr}$ and the uranium ingestion conversion factors gives the maximum annual dose during 70 yr of continuous exposure. The maximum annuai ingestion dose from uranium is $2.53 \mathrm{mrem}$ to bone. This corresponds to $0.21 \mathrm{mrem}$ to bone lining.

Strontium. Calculation of the ${ }^{90} \mathrm{Sr} / \mathrm{calcium}$ ratio in fruits and vegetables grown in the garden depends on the ${ }^{90} \mathrm{Sr}$ surface contamination. The calculation presented here follows that of Healy et al., l who use a $20-\mathrm{cm}$ soil depth. Using a density of $1.4 \mathrm{gm} / \mathrm{cm}^{3}$ (Ref. 7 ) and an above-background ${ }^{90} \mathrm{Sr}$ soil concentration of $0.5 \mathrm{pCi} / \mathrm{g}$, the ${ }^{90} \mathrm{Sr}$ surface contamination is $140 \mathrm{mCi} / \mathrm{km}^{2}$. Concentration $\mathrm{M}$ (in $\mathrm{pC} i{ }^{90} \mathrm{Sr} / \mathrm{g}$ calcium) in the diet from an initial deposit of ${ }^{90} \mathrm{Sr}$ in the soil, $\mathrm{F}$ (in $\mathrm{mCi} / \mathrm{km}^{2}$ ), is given by ${ }^{l}$

$$
\begin{aligned}
M_{1} & =1.03 \mathrm{~F} \text { for vegetables } \\
& =144 \mathrm{pCi}{ }^{90} \mathrm{Sr} / \mathrm{g} \text { calcium and } \\
M_{2} & =0.90 \mathrm{~F} \text { for fruit } \\
& =126 \mathrm{pCi}{ }^{90} \mathrm{Sr} / \mathrm{g} \text { calcium. }
\end{aligned}
$$

Vegetable and fruit consumption is expected to provide $8.9 \%$ and $3.9 \%$ of the calcium in the diet, respectively. The calcium provided by food grown on the contaminated area is $4.5 \%(1 / 2 \times 8.9 \%)$ and $1.3 \%$ 
$(1 / 3 \times 3.9 \%)$ of the total. The resulting weighted ${ }^{90} \mathrm{Sr} / \mathrm{calcium}$ ratio in the diet would be

$$
(0.045)(144)+(0.013)(126)=8.12-p C i{ }^{90} \mathrm{Sr} / \mathrm{g} \text { calcium. }
$$

The ${ }^{90} \mathrm{Sr} / \mathrm{calcium}$ ratio in bone is 0.14 that in the diet, ${ }^{8}$ or $1.14 \mathrm{pCi}$ ${ }^{90} \mathrm{Sr} / \mathrm{g}$ calcium. (This is a conservative assumption because ${ }^{90} \mathrm{Sr}$ reaches equilibrium in bone slowly.) Using dose conversion factors of $(1.4 \mathrm{mrad} / \mathrm{yr}) /(\mathrm{pC} ; 90 \mathrm{Sr} / \mathrm{g}$ calcium) for bone marrow and $(1.9$

$\mathrm{mrad} / \mathrm{yr}) /\left(\mathrm{pCi}{ }^{90} \mathrm{Sr} / \mathrm{g} \mathrm{calcium}\right)$ for bone surfaces, the bone marrow and bone surface doses are 1.60 and $2.2 \mathrm{mrem} / \mathrm{yr}$, respectively.

This dose calculation does not take into account evidence showing ${ }^{90} \mathrm{Sr}$ to be less biologically mobile the longer it is in the environment, which would result ir. less uptake by $\mathrm{plants}$ and lower doses to man. 1 Because the ${ }^{90} \mathrm{Sr}$ has been present at Bayo Canyon for at least $19 \mathrm{yr}$, the actual dose could be significantly less than this estimated dose.

The estimated maximum total annual ingestion dose of 4.73 mrem is lower than that calculated previously. ${ }^{6}$ The dose estimate presented here agrees with the current understanding of the radiological and environmental behavior of ${ }^{90} \mathrm{Sr}$, the radionuclide that accounted for the greatest part of the dose estimated in the previous report.?

To illustrate the compatibility of this dose estimate with other assessments, the ${ }^{0}{ }^{\circ} \mathrm{s}$ ingestion dose can be compared with the falloutdeposited ${ }^{0}$ Sr dose calculated by the UN Scientific Committee on the Effects of Atomic Radiation (UNSCEAR). ${ }^{7}$ This committee estimated the ${ }^{9} \mathrm{Sr}$ population weighted deposition density from fallout to be 85.1 $\mathrm{mCi} / \mathrm{km}^{2}$. Measurements of ${ }^{90} \mathrm{Sr}$ to calcium ratios in adult vertebrae generally lie between 1 and $2 \mathrm{pCi} 90 \mathrm{Sr} / \mathrm{g}$ calcium. This corresponds to a bone surface dose of 1.9 to $3.8 \mathrm{mrad} / \mathrm{yr}$. The above-background Bayo Canyon ${ }^{90} \mathrm{Sr}$ concentration of $140 \mathrm{mCi} / \mathrm{km}^{2}$ is slightly larger than the fallout value, whereas the consumption rate of Bayo Canyon fruits and vegetables is smaller than the total diet consumption rate that would apply for the fallout situation. Ingestion doses from abovebackground Bayo Canyon ${ }^{90} \mathrm{Sr}$ levels would be expected to be approximately the same as those calculated for fallout. The 2.73 $\mathrm{mrem} / \mathrm{yr}$ estimated here for the ${ }^{90} \mathrm{Sr}$ ingestion dose is in reasonable agreement with that from UNSCEAR for similar levels of $90 \mathrm{Sr}$ intake. Revision of the previous estimate of maximum ingestion dose to the present value, therefore, is thought to be appropriate.

\subsection{Doses to Construction and Cleanup Workers}

Doses to workers were calculated using the $50-y r$ dose commitment factors from Table B-III. A dust loading of $400 \mu \mathrm{g} / \mathrm{m}^{3}$ and breathing rate of $43 \mathrm{l} / \mathrm{min}$, typical of a man engaged in physical work, ${ }^{9}$ were used. Radionuclide soil concentrations depended on the soil layer being disturbed, which, in turn, depended on the activity being performed. These are summarized in Table B-IV. 
Doses due t's inhalation of dust containing ${ }^{90} \mathrm{Sr}$ contamination are less than those estimated in Ref. 7. As discussed above, for ${ }^{90} \mathrm{Sr}$ ingestion, these present estimates agree with data summarized by UNSCEAR. In addition, the value used for dust loading was reduced from $10 \mathrm{mg} / \mathrm{m}^{3}$ to $400 \mathrm{\mu g} / \mathrm{m}^{3}$, which is more representative of the average dust loading under these conditions.

\subsection{Doses Resulting from Transportation of Bayo Soil to TA-54}

2.4.1 Dose to the Driver of a Truck Hauling Contaminated Soil.

The driver can receive radiation doses from external radiation emitted by the contaminated soil and from inhalation of contaminated material resuspended from the soil carried by the truck. Two types of external radiation are expected from the contaminated soil: B radiation emitted by the ${ }^{90} \mathrm{Sr}$ and $90 \mathrm{Y}$ nuclei and photon bremsstrahlung, or "braking," radiation resulting from $\beta$ particles losing energy in interactions with nuclei in either the soil or the truck walls.

\subsubsection{Beta Dose. Beta radiation would be totally} absorbed by the truck walls. The maximum $B$ energy is $2.27 \mathrm{MeV}$, which is the maximum energy of the $B$ particles emitted by $90 y$. The $r$ ange of this particle is $1.1 \mathrm{~g} / \mathrm{cm}^{2}$. 10 Given the density of iron as $7.86 \mathrm{~g} / \mathrm{cm}^{3}$, this $\beta$ range is $0.14 \mathrm{~cm}$, or $0.055 \mathrm{in}$. Because this is less than the 0.125-in. thickness typical of truck bed walls, no $\beta$ radiation would penetrate to the driver.

\subsubsection{Bremsstrahiung Dose. An upper limit to the} radiation dose from bremsstrahtung was estimated by calculating the photon intensity at the surface of an infinite half-space of soil having a ${ }^{90} \mathrm{Sr}$ concentration of $1100 \mathrm{pCi} / \mathrm{g}$. The actual dose to the driver would be less than this dose because of the finite size of the load and the average soil concentration probably being considerably lower than $1100 \mathrm{pCi} / \mathrm{g}$. The bremsstrahiung dose is calculated from this photon intensity, attenuated by the $5 \mathrm{~g} / \mathrm{cm}^{2}$ thickness of the truck bed and cab walls. Attenuation from material inside the $c a b$, as well as self-shielding by the body, was ignored.

At equilibrium, the ${ }^{90} \mathrm{Sr}$ and $9 \mathrm{C}_{\mathrm{Y}}$ soil concentrations, $C_{j}$, would both be $1100 \mathrm{pCi} / \mathrm{g}$. Following Cember, 11 the fraction $f_{j}$ of incident $\beta$ energy converted into photons in a material of atomic number $Z$ is given by

$$
f_{i}=3.5 \times 10^{-4} Z_{E_{j}} \text {, }
$$

where $E$ is the maximum $B$ particle energy in a million electron volts (MeV) for ${ }^{90} \mathrm{Sr}(i=1)$ or $90 \mathrm{Y}(i=2)$. Assuming soil to have the composition given in Table B-IV, the effective $Z$ is calculated to be 9.65. Because $E=0.546 \mathrm{MeV}$ for ${ }^{90 \mathrm{Sr}}$ and $2.2 \mathrm{MeV}$ for $90 \mathrm{Y}$, the vaiues of $f$ are $0.0018\left({ }^{90} \mathrm{Sr}\right)$ and $0.0077(90 \mathrm{Y})$.

Next, a virtual photon emission rate is assigned to each volume element $V$. This emission rate is assumed to be uniform throughout the infinite half-space. This is a valid assumption except near the edge 
TABLE B-IV

WORK PARAMETERS FOR EXCAVATION SCENARIOS

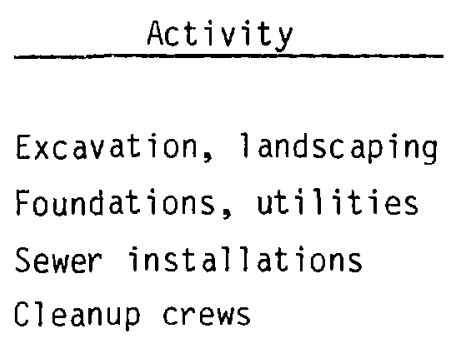

$\begin{array}{cll}\text { Soi1 Layer } & & \text { Exposure Time } \\ 0-30 \mathrm{~cm} & & 2000 \mathrm{~h} / \mathrm{yr} \\ 0-122 \mathrm{~cm} & 360 \mathrm{~h} \\ 122-244 \mathrm{~cm} & 60 \mathrm{~h} \\ 122-244 \mathrm{~cm} & 480 \mathrm{~h}\end{array}$

TABLE B-V

SOIL COMPOSITION BY WEIGHT USED IN DETERMINING EFFECTIVE ATOMIC NUMBER AND SOIL-TO-BREMSSTRAHLUNG DOSE CONVERSION FACTOR ${ }^{a}$
$\mathrm{Al}_{2} \mathrm{O}_{3}$
0.135
$\mathrm{Fe}_{2} \mathrm{O}_{3}$
0.045
$\mathrm{SiO}_{2}$
0.675
$\mathrm{CO}_{2}$
0.045
$\mathrm{H}_{2} \mathrm{O}$
0.10

a Taken from Ref. 12 . 
of the space, where it would be conservative. The volume element would contain activity $C_{j}$ DV each of ${ }^{9}{ }^{0} \mathrm{Sr}$ and $90 \mathrm{Y}$, where $\mathrm{D}$ is the soil density. Then the $B$ energy produced by each radionuclide per unit time, $W_{j}$, in $V$ is

$$
W_{i}=E_{j} C_{j} D V / 3
$$

This expression uses the fact that the average $\beta$ energy is approximately one-third the maximum $\beta$ energy.

The photon activity from each radionuclide, $Q_{i}$, in $V$ is

$$
\begin{aligned}
Q_{j} & =f_{i} W_{j} / E_{i} \text { and } \\
Q_{i} & =f_{i} E_{i} C_{j} D V / 3 E_{i} \\
& =f_{j} C_{j} D V / 3,
\end{aligned}
$$

where it is assumed conservatively that all photons have an energy equal to the maximum $B$ energy. The photon activity frorn each radionuclide per gram of soil is

$$
\left(\frac{Q}{m}\right)_{i}=\left(\frac{Q}{D V}\right)_{i}=f_{i} C_{i} / 3 \text {. }
$$

For $1100 \mathrm{pCi} / \mathrm{g}=40.7 \mathrm{dps} / \mathrm{g}$, this activity per gram is equal to 0.0244 and 0.1041 photons $/ \mathrm{s} / \mathrm{g}$ for $90 \mathrm{Sr}$ and $90 \mathrm{Y}$, respectively.

Exposure rates were determined from interpolating conversion factors from Beck et al.12 For 0.546 and $2.27 \mathrm{MeV}$ photons, the conversion factors used are 15.88 and $70.12(\mu R / \mathrm{h}) /(\mathrm{gamma} / \mathrm{s} / \mathrm{g})$, respectively. These factors were calculated for a radiation field at $1 \mathrm{~m}$ above the surface of contaminated soil occupying an irifinite halfspace. They include contributions from photons scattered by air and soil as well as unscattered photons.

Using the photon activity per gram previously calculated for ${ }^{90} \mathrm{Sr}$ and $90 \mathrm{y}$ and the above conversion factors, the photon exposure levels at $1 \mathrm{~m}$ are

$$
\begin{aligned}
& (15.88)(0.0244)=0.39 \mu R / h \text { and } \\
& (70.12)(0.104)=7.30 \mu R / h .
\end{aligned}
$$

Shielding by the cab or truck walls would reduce this exposure level. Both the truck bed and cab walls were assumed to be $0.125-$ in.thick steel, providing some $0.25 \mathrm{in}$. of shielding in all. Mass attenuation coefficients in iron for 0.546 - and 2.27-MeV photons are approximately 0.0769 and $0.0410 \mathrm{~cm}^{2} / \mathrm{g}$, respectively. 10 The relaxation lengths $\mu x$ are 0.384 and 0.205 . Interpolated estimates of build-up factors for these values of $\mu x$ are 1.41 and 1.14.10 The exposure rates would then be 


$$
\begin{aligned}
& X=(0.39)(1.41) e^{-0.384}=0.38 \mu R / h \text { and } \\
& X=(7.30)(1.14) e^{-0.205}=\frac{6.79}{T .17} . \\
& \text { TOTAL }
\end{aligned}
$$

Total dose to the driver was estimated assuming that the ariver would haul contaminated soil for $125 \mathrm{~h}$. The total exposure would be

$$
7.17 \frac{\mu R}{h} \quad(125 h)=0.90 \mathrm{mR}=0.85 \mathrm{mrem} \text {, }
$$

where $1 \mathrm{R}$ equals $0.95 \mathrm{rad}$ and the photon qual ity factor equals one.

Doses from bremsstrahlung due to $\beta$ particle deceleration in the truck walls also were calculated. While the fraction $f$ of $\beta$ energy changed to bremsstrahlung radiation was higher than that for soil because of the higher atomic number of the iron, the overall dose was lower than that estimated above because of the smaller number of $B$ particles involved. A procedure similar to that used above estimated this dose to be less than $0.01 \mathrm{mrem}$.

The total dose of $0.85 \mathrm{mrem}$ is $0.2 \%$ of the $500 \mathrm{mrem} / \mathrm{yr}$ allowed members of the public and $0.02 \%$ of the $5 \mathrm{rem} / \mathrm{yr}$ occupational radiation dose limit.

2.4.1.3 Inhalation Dose. The soil will be covered while being transported, so that a negligible amount of material would be available for wind transport and eventual inhalation by the driver. Doses resulting from this exposure mechanism would be correspondingly small.

While the driver was not in transit to the waste disposal site and back, he was assumed to be in Bayo Canyon with the cleanup crer. of the estimated $480 \mathrm{~h}$ to remove the contaminated soil, the driver would spend $250 \mathrm{~h}$ going and coming from TA-54 and $230 \mathrm{~h}$ at Bayc Canyon. His dose while at the work site was calculated like that for other workers (Section 2.3) but with a 230-h exposure time.

\subsubsection{Doses Resulting from an Accidental Spill of Contaminated} Soil. To evatuate the radiological impact of an accidental spitT, the assumption was made that an entire truckload of contaminated soil, some $5.4 \mathrm{~m}^{3}\left(7 \mathrm{yd}^{3}\right)$, was deposited in a populated area. The soil was removed $24 \mathrm{~h}$ later. Doses from longer or shorter exposure times can be approximated by scaling the $24-h$ value calculated here.

The principal exposure route is through inhalation of resuspended material. Inhalation doses were based on the maximum predicted air concentration of $4.29 \mathrm{mg} / \mathrm{m}^{3}$. This air concentration was based on the following meteorological assumptions.

1. Eight hours each of $D, E$, and $F$ atmospheric stability

2. A constant wind speed of $2 \mathrm{~m} / \mathrm{s}$

3. A constant wind direction toward the receptor location 
A maximum upper limit on the source term was estimated by assuming that all particles less than $20 \mathrm{~mm}$ were resuspended by wind and mechanical forces. This was approximately $14 \%$ of the total mass.' The resulting average $24-h$ dust loading is an order of magnitude higher than those usually encountered. It is used here to estimate the maximum dust loading over a short 24-h period, which would be higher than the average for longer time periods. It also ignores dust control measures that would be taken to prevent the spread of spilled material, such as covering the soil to prevent wind erosion, or watering down the soil while it is being removed to reduce wind and mechanical resuspension.

The airborne dust concentration was multiplied by a breathing rate of $23 \mathrm{~m}^{3} /$ day and a soil concentration of $1100 \mathrm{pCi} / \mathrm{g}$ to obtain a ${ }^{90} \mathrm{Sr}$ intake of $107.8 \mathrm{pCi}$. Doses corresponding to this intake were. calculated from the 50-yr dose commitment conversion factors given in Table B-III.

\section{REFERENCES}

1. J. W. Healy, J. C. Rodgers, and C. L. Wienke, "Interim Soil Limits for D\&D Projects," Los Alamos Scientific Laboratory report LA-UR-79-1865-Rev. (September 12, 1979).

2. National Council on Radiation Protection and Measurements, "Basic Radiation Protection Criteria," NCRP report 39 (1971).

3. International Commission on Radiological Protection Task Group on Lung Dynamics, "Deposition and Retention Models for Internal Dosimetry of the Human Respiratory Tract," Health Physics 12: 173-207 (1966).

4. International Commission on Radiological Protection, "The Metabolism of Compounds of Plutonium and Other Actinides," ICRP publication 19, Pergamon Press, 0xford (1972).

5. K. Z. Morgan and J. E. Turner, Principles of Radiation Protection (Robert E. Krieger Publishing Co. Inc., Hunt ington, New York, 1973), p. 324.

6. D. E. Dunning, Jr., S. R. Bernard, P. J. Walsh, G. G. Killoveh, and J. C. Pleasant, "Estimates of Internal Dose Equivalent to 22 Target Organs for Radionuclides Occurring in Rout ine Releases from Nuclear Fuel Cycle Facilities," Oak Ridge National Laboratory report ORNL/NUREG/TM-190/V2, Vol. 2 (October 1979).

7. Los Alamos Scientific Laboratory, "Radiological Survey of the Bayo Canyon, Los Alamos, New Mexico," Department of Energy report DOE/EV-0005/15 (June 1979). 
8. United Nations Scientific Committee on the Effects of Atomic Radiation, "Sources arúf F.ffects of Ionizing Radiation," New York (1977).

9. International Commission on Radiological Protection, "Report of the Task Group on Reference Man," ICRP publication 23, Pergamon Press, 0xford (1975).

10. US Public Health Service, "Radiologicai Health Handbook," US Department of Health, Educatiun, and Welfare publication, US Government Printing Office (January 1970).

11. H. Cember, Introduction to Health Physics (Pergamon Press, New York, 1969), pp. 118-119.

12. H. L. Beck, J. DeCampo, and C. Gogolak, "In situ Ge(Li) and NaI(T1) Gamma-Ray Spectrometry," Health and Safety Laboratory report HASL-258 (September 1.772). 
APPENDIX C

PLANTS OF PUEBLO CANYON

Anacardiaceae

Rhus trilobata

Anaranthaceae

Amaranthus retroflexus

Boraginaceae

Cryptantha jamesii

Lappula spp.

Lithnspermum spp.

Cactaceae

Echinocereus spp.

Opuntia polycantha

Capparidaceae

Polansia trachyspermum

Chenopodiaceae

Atriplex canescens

Chenopodium graveolans

Chenopodium fremontii

Salsola kali

Compositae (Asteraceae)

Antennaria parvifolia

Artemisia carruthii

Artemisia dracunculoides

Artemisia frigida

Artemisia 1udoviciana

Artemisia tridentata

Aster bigelovii

Aster hesperius

Bahia dissecta

Brickellia californica

Chrysopsis villosa

Chrysothamnus nauseosus

Conyza canadensis

$$
\begin{aligned}
& \text { Compositae (cont) } \\
& \text { Cosmos parviflorus } \\
& \text { Dyssodia papposa } \\
& \text { Erigeron divergens } \\
& \text { Franseria spp. } \\
& \text { Gaillardia pulchella } \\
& \text { Gutierrer:a microcephala } \\
& \text { Happlopapus spinulosis } \\
& \text { Helianthus annuus } \\
& \text { Helianthus petiolaris } \\
& \text { Hymenopappus spp. } \\
& \text { Hymenoxys argentea } \\
& \text { Hymenoxys richardsonii } \\
& \text { Lactuca serriola } \\
& \text { Senecio multicapitatus } \\
& \text { Thelesperma trifidum } \\
& \text { Tragopogon dubius } \\
& \text { Viguiera multiflorum }
\end{aligned}
$$

Cruciferae

Descurainia spp.

Cupressaceae

Juniperus monosperma

Juniperus scopulorum

Cyperaceae

Carex spp.

Euphorbiaceae

Croton texensis

Euphorbia dentata

Euphorbia serpyllifolia

Fagaceae

Quercus gambelii

Quercus undulata 
APPENOIX C (cont)

Geraniaceae

Erodium circutarium

Geranium caespitosum

Gramineae (Poaceae)

Agropyron desertorum

Agropyron smithii

Andropogon scoparius

Aristida divaricata

Bouteloua curtipendulum

Bouteloua eriopoda

Bouteloua gracilis

Bromus spP.

Bromus tectorum

Festuca spp.

Koelaria cristata

Muhlenbergia montana

Munroa squarrosa

Oryzopsis hymenoides

Poa spp.

Sitanion hystrix

Sporobolus contractus

Sporobolus spp.

Hydrophyllaceae

Phacelia spp.

Labiatae

Monarda pectinata

Leguminosae (Fabaceae)

Lupinus caudatus

Robinia neomexicana

Vicia americana

Liliaceae

Allium cernuum

Yucca baccata
Loasaceae

Mentzelia pumila

Malvaceae

Sphaeralcea incana

Nyctaginaceae

Mirabilis linearis

Mirabilis multiflorum

Oleaceae

Forestiera neomexicana

Onagraceae

Denothera spp.

Orobanchaceae

Orobanche multiflorum

Pinaceae

Pinus edulis

Pinus ponderosa

Plantaginaceae

Plantago purshii

Polemoniaceae

Gilia aggregata

Gilia longiflora

Gilia spp.

Polygonaceae

Eriogonum cernuum

Eriogonum jamesii

Rumex spp.

Portulacaceae

Portulaca oleracea

Ranuncrlaceae

Pulsatilla ludoviciana 


\section{APPENDIX C (cont)}

Rosaceae

Cercocarpus montanus

Fallugia paradoxa

Potentilla spp.

Prunus virglniana, var. melanocarpa

Rutaceae

Ptelea angustifolia

Salicaceae

Populus angustifolia

Saxifragaceae

Philadelphus microcephala

Scrophulartaceae

Castilleja integra

Orthocarpus purpureo-albus

Penstemon barbatus, var. torreyi

Verbascum thapsis

\author{
Solanaceae \\ Datura meteloides \\ Physalis neomexicana \\ Tamaricaceae \\ Tamarix gallica \\ Urticaceae \\ Urtica gracilis \\ Vitaceae \\ Parthenocissus inserta
}


TABLE D-I

MAMMALS

\begin{tabular}{|c|c|c|}
\hline $\begin{array}{l}\text { Verified } \\
\text { to Be } \\
\text { in Area }\end{array}$ & $\begin{array}{l}\text { Presence } \\
\text { Reported or } \\
\text { Suspected }\end{array}$ & $\begin{array}{c}\text { Threatened } \\
\text { or } \\
\text { Endangered }\end{array}$ \\
\hline
\end{tabular}

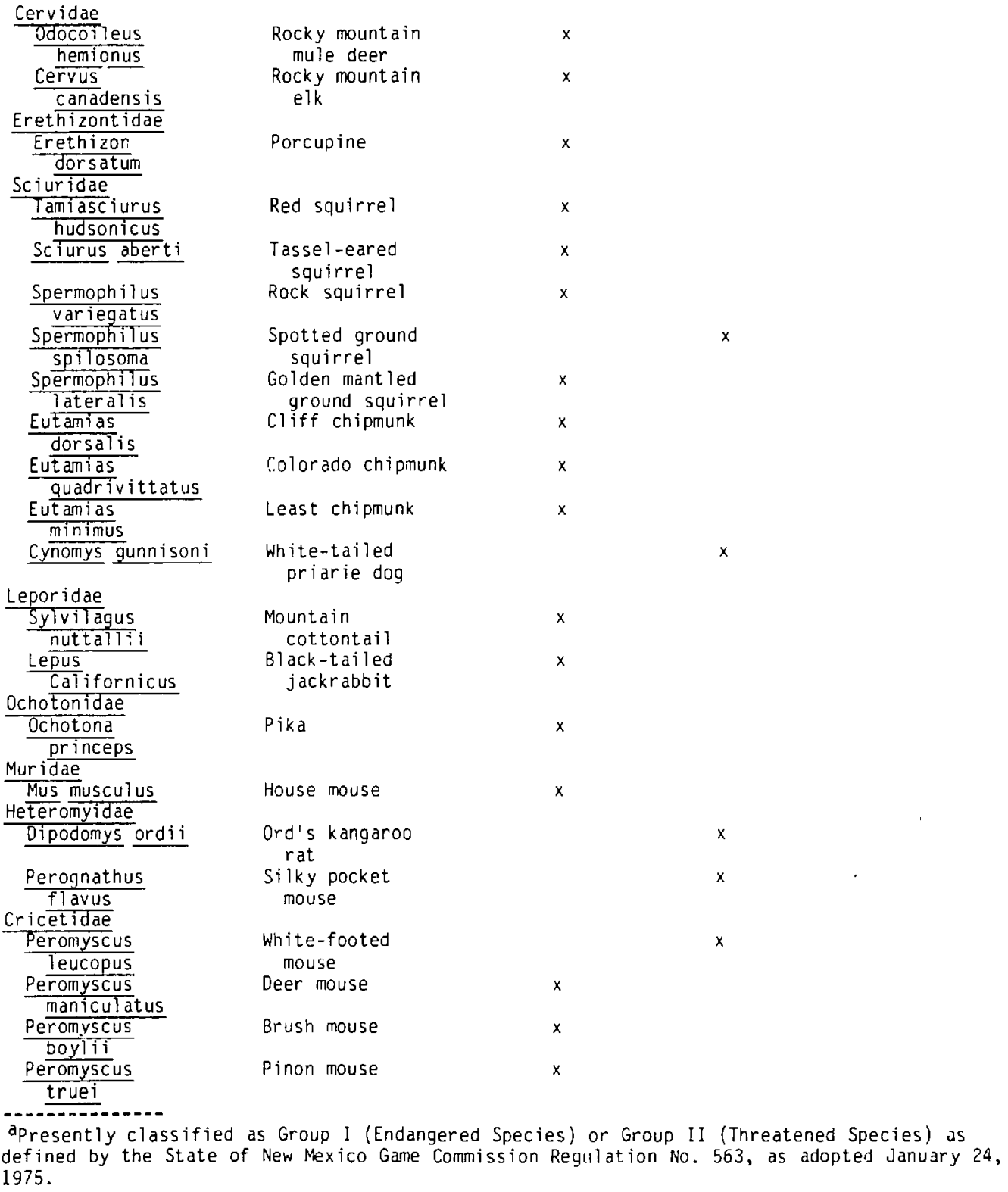


TABLE D-I (cont)

\begin{tabular}{ccc}
$\begin{array}{c}\text { Verified } \\
\text { to Be }\end{array}$ & $\begin{array}{c}\text { Presence } \\
\text { Reported or } \\
\text { Suspected }\end{array}$ & $\begin{array}{c}\text { Threatened } \\
\text { or } \\
\text { Endangered }\end{array}$ \\
\hline
\end{tabular}

Cricetidae (cont)

Reithrodontomys

megalot is

Clethrionomys

gapperi

Microtus

montanus

Microtus

longicaudus

Microtus

pennsyivanicus

Geomyidae

Thomomys bottae

Thomomys

talpoides

Soricidae

Sorex nanus

Sorex vagrans

Procyonidae

Procyon Totor

Mustelidae

Taxidea taxus

Martes americ ana

Mustela erminea

Mustela

nigripes

Mephitis

mephitis

Canidae

Urocyon cinereo-

argenteus

vuTpes futva

Canis Tatrans

Ursidae

Ursus americanus

Felidae

Lynx rufus

Fetis concalor

Castoridae

castor

Western harvest

$x$

ouse

Gappers red-

backed vole

Montane vole

Long-tailed vole

$x$

Meadow vole

$x$

Valley pocket gopher

Northern packet $x$

gopher

Dwarf shrew

Vagrant shrew $x$

Raccoon $x$

American badger $x$

Pine marteri

Ermine/Short-tail

weasel

81 ack-footed

ferret

Striped skunk

$x$

Grey fox $x$

Red fox

Coyote

Black bear

Bobcat

Mountain Tion

\section{$x$}

$x$

$x$

$x$

$x$

$x$

Beaver

$x$ 
TABLE D-II

AMPHIBIANS AND REPTILES
Presence

Reportef or

Suspected
Threatened ${ }^{\mathrm{a}}$

or

Endangered

Plethodontidae

plethodon

neomexic anus

Tei idae

Chemidophorus spp.

Iguanidae

Phrynosoma spp.

Crotaphytus

coliaris

Sceloporus

magister

Viperidae

Crotalus

viridis

Colubridae

Pituophis

metanoteucas

Thamnophis

sirtalis

Thamnophis

elegans

Lampropelt is getulus

Jemez Mountain

$x$

$x$

Whiptail

Horned lizard

Collared lizard

Desert spiny

lizard

Prairie rattlesnake

Bull snake

Common garter

snake

Western garter

snake

Cormon king

snake $x$

$x$

$x$

$x$

$x$

$x$

$x$

$x$

$x$ 
TABLE D-III

FISH

\begin{tabular}{ccc}
$\begin{array}{c}\text { Verified } \\
\text { to Be } \\
\text { in Area }\end{array}$ & $\begin{array}{c}\text { Presence } \\
\text { Reported or } \\
\text { Suspected }\end{array}$ & $\begin{array}{c}\text { Threatened }^{\mathbf{a}} \\
\text { or } \\
\text { Endangered }\end{array}$ \\
\hline
\end{tabular}

Catostomidae

Catostomus

commersoni

White sucker

Carpoides carpio

Cyprinidae

Cyprinus carpio

Hybops is spp.

SaTmonidae

Salmo trutta

Carp-sucker

$x$

Carp

Chub

$x$

X

Brown trout

X 
TABLE D-IV

BIRDS

\begin{tabular}{|c|c|c|c|c|c|c|}
\hline $\begin{array}{l}\text { Nest } \\
\text { in } \\
\text { Area }\end{array}$ & $\begin{array}{l}\text { Summer }{ }^{a} \\
\text { Resident }\end{array}$ & $\begin{array}{l}\text { Yearlong } \\
\text { Resident }\end{array}$ & $\begin{array}{l}\text { Winter } \\
\text { Resident }\end{array}$ & Migrant & $\begin{array}{l}\text { Casual or } \\
\text { Irregular }\end{array}$ & Uncammon \\
\hline
\end{tabular}

Gavilformes

Gavia inimer

Podicipiformes

Common loon

Resident

Resident

Resident

Migrant

Irregular

Uncommon

Podicep caspicus

Anseriformes

Branta canadens is

Knas platyrhynchos

Anas strepera

Anas acuta

Anas $\frac{\text { carotinensis }}{\text { carotins }}$

Anas discors

Anas cyanoptera

Marec a americana

Spatula clypeata

Aythya collaris

Aythya affinis

Bucephata atbeola

Oxyura jamaicensis

Mergus merganser

Fatcorifformes

Cathartes aura

Accipiter gentilis

Accipiter striatus

Accipiter cooperii

Euteo jamaicensis

3uteo albonotatus

Buteo Tagopus

Buteo regalis

Eared grebe

Canada goose

Mallard

Gadwall

Pintail

Green-winged teal

Blue-winged teal

Cinnamon teal

American widgeon

Shoveler

Ring-necked duck

Lesser scaup

Bufflehead

Ruddy duck

Cominon merganser

Turkey vulture

Goshawk

Sharp-shinned hawk

Cooper's hawk

Red-tailed hawk

Zone-talled hawk

Rough-legged hawk

Ferruginous hawk

Aquila chrysaetos

Circus cyaneus

Golden eagle

Marsh hawk

0sprey

Falco mexicanus

$\frac{\text { Falco mexicanus }}{\text { Falco }}$

Prairie falcan ${ }^{b}$

Peregrine falcon ${ }^{b}$

Merl in (pigeon hawk)

co columbari

American kestrel

Blue grouse

Scaled quail

Dendragapus

obscurus

CalTipepla

squamata

Lophor tyx gambel ii

Melagris gallopavo

Gruiformes

Grus americana

Grus canadensís

RaTTus Timicola

Porzana carolina

Gambel's quai]

Wild turkey

Whooping crane ${ }^{C}$

Sandhili crane

Virginia rai]

Sora

This catejory only covers summer residents that nest in the area. Clearly yeariong residents also nest in the area.

bresently classified as Group II (Threatened Species) as defined above.

CPresently classified as Group I (Endangered Species) as defined by the State of New Mexico Game Cormission Regulation No. 563 , as adopted January 24, 1975. 
TABLE D-IV (cont)

\begin{tabular}{|c|c|c|c|c|c|c|}
\hline $\begin{array}{l}\text { Nest } \\
\text { in } \\
\text { Area }\end{array}$ & $\begin{array}{l}\text { Summer a } \\
\text { Resident }\end{array}$ & $\begin{array}{l}\text { Yearlong } \\
\text { Resident }\end{array}$ & $\begin{array}{l}\text { Winter } \\
\text { Resident }\end{array}$ & Migrant & $\begin{array}{l}\text { Casual or } \\
\text { Irreqular }\end{array}$ & Une ombin \\
\hline
\end{tabular}

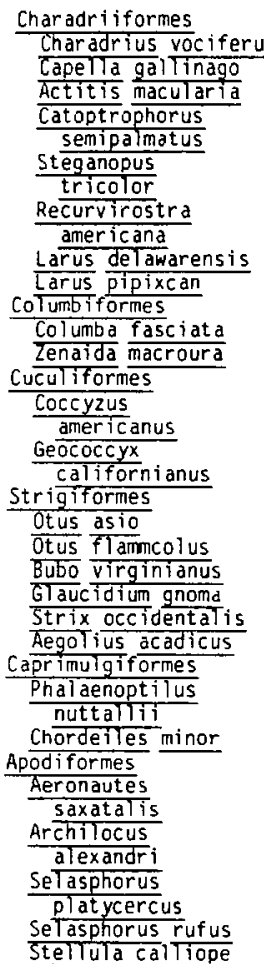

Killdeer

Common snipe

Spotted sandpiper

willet

Wilson's

phalarope

American avocet

Ring-billed guli

Franklin's gull

Band-tailed pigeon

Mourning dove

Yellow-billed

cuckoo

Roadrunner

Screech ow

Fin, millated ow

Gi at irned ow

Pyy 0 H.

Spottec ow

Saw-whet $0 \cdot i$

Poor-will

Common nighthawk

White-throated

swift

Black-chinned hummingbird

Broad-tailed

humningbird

Rufous hummingbird

Calliope

hummingbird

Piciformes

Colaptes auratus

Melanerpes

formicivorus

MeTanerpes

erythrocephalus

Sphyrapicus

varius

sphyrapicus

thyroideus

Dendrocopos

villosus

Common flicker

Acorn woodpecker

Red-headed

woodpeckerb

Yellow-bellied

sapsucker

Williamson's sapsucker

Hairy

woodpecker

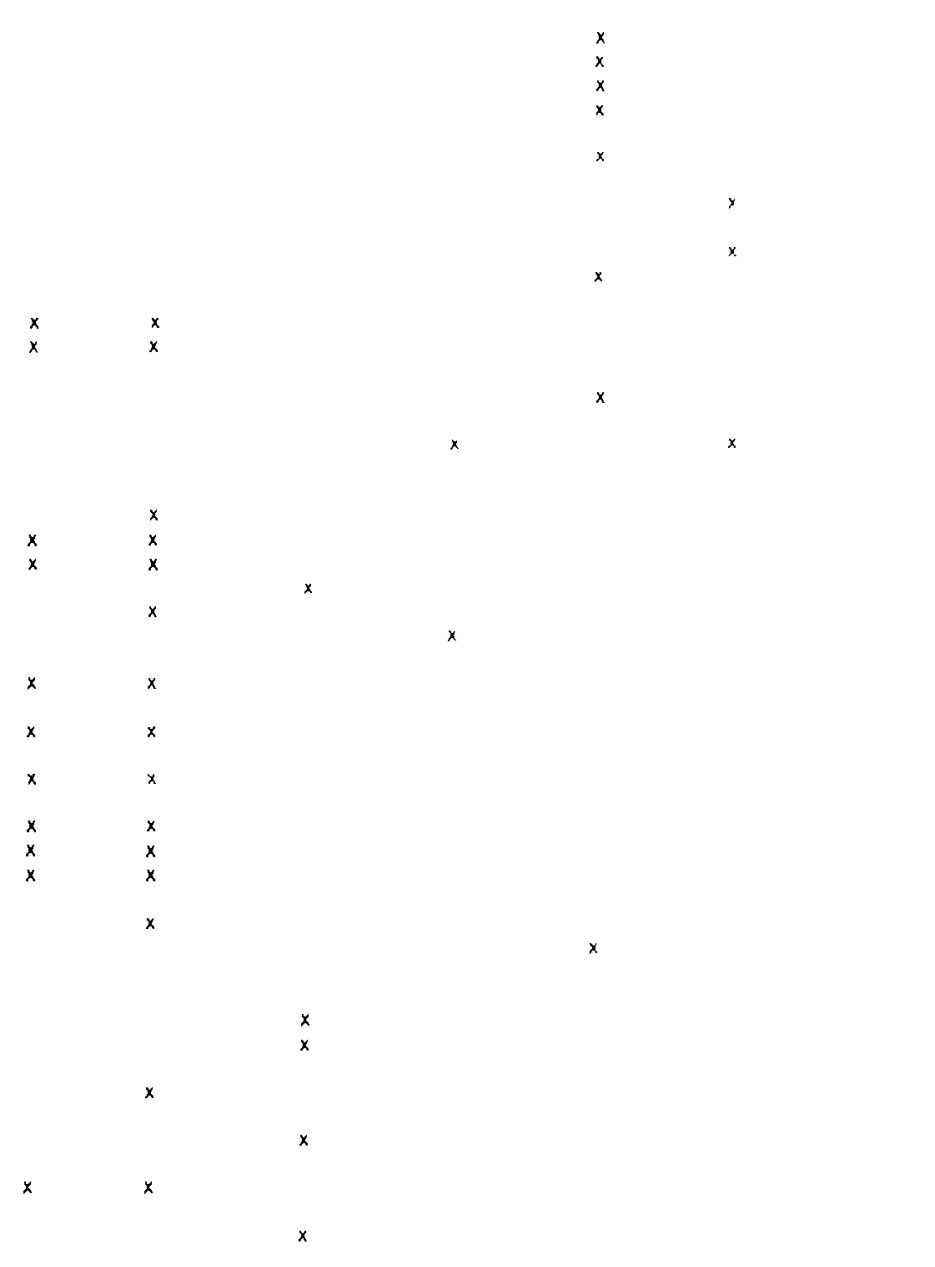


TABLE D-IV (cont)

\begin{tabular}{|c|c|c|c|c|c|c|c|c|}
\hline & & $\begin{array}{c}\text { Nest } \\
\text { in } \\
\text { Area } \\
\end{array}$ & $\begin{array}{l}\text { Summer }{ }^{\mathrm{a}} \\
\text { Resident }\end{array}$ & $\begin{array}{l}\text { Yearlong } \\
\text { Resident } \\
\end{array}$ & $\begin{array}{l}\text { Winter } \\
\text { Resident }\end{array}$ & Migrant & $\begin{array}{l}\text { Casual or } \\
\text { Irregular }\end{array}$ & Uncommon \\
\hline \multicolumn{9}{|l|}{ Piciformes (cont) } \\
\hline$\frac{\text { Dendrocopos }}{\text { pubescens }}$ & $\begin{array}{l}\text { Downy } \\
\text { woodpecker }\end{array}$ & & & $x$ & & & & \\
\hline$\frac{\text { Dendrocopos }}{\text { scalaris }}$ & $\begin{array}{l}\text { Ladder-backed } \\
\text { woodpecker }\end{array}$ & & $x$ & & & & & \\
\hline Passyndesmus lewis & Lewis woodpecker & & & & & $x$ & & \\
\hline Passertformes & & & & & & & & \\
\hline$\frac{\text { Tryannus }}{\text { vociferans }}$ & $\begin{array}{l}\text { Cassin's } \\
\text { kingbird }\end{array}$ & $x$ & $x$ & & & & & \\
\hline$\frac{\text { Myiarchus }}{\text { cinerascens }}$ & $\begin{array}{l}\text { Ash-throated } \\
\text { flycatcher }\end{array}$ & $x$ & $x$ & & & & & \\
\hline Sayornis & Say's phoebe & $x$ & $x$ & & & & & \\
\hline$\frac{\frac{\text { saya }}{\text { Empidonax }}}{\text { trailiji }}$ & $\begin{array}{l}\text { Traill's } \\
\text { flycatcher }\end{array}$ & $x$ & $x$ & & & & & \\
\hline$\frac{\text { Empidonas }}{\text { hammondii }}$ & $\begin{array}{l}\text { Hammond's } \\
\text { flycatcher }\end{array}$ & $x$ & $x$ & & & & & \\
\hline$\frac{\text { Empidondx }}{\text { oberholseri }}$ & $\begin{array}{l}\text { Dusky } \\
\text { flycatcher }\end{array}$ & & $x$ & & & & & \\
\hline$\frac{\text { Empidonax }}{\text { wrightij }}$ & $\begin{array}{l}\text { Gray } \\
\text { f fycatcher }\end{array}$ & $x$ & $x$ & & & & & \\
\hline$\frac{\text { Empidonax }}{\text { difficilis }}$ & $\begin{array}{l}\text { Western } \\
\text { f l ycatcher }\end{array}$ & $x$ & $x$ & & & & & \\
\hline Contopus & Western & & & & & & & \\
\hline sordidulus & wood pewee & $x$ & $x$ & & & & & \\
\hline$\frac{\text { Nuttallornis }}{\text { borestis }}$ & $\begin{array}{l}\text { flycatcher } \\
\text { flye-sided }\end{array}$ & $\lambda$ & $x$ & & & & & \\
\hline$\frac{\text { Eremophita }}{\text { olpestris }}$ & Horned lark & & & & & $x$ & & \\
\hline$\frac{\text { Techycineta }}{\text { thalassina }}$ & $\begin{array}{l}\text { Violet-green } \\
\text { swallow }\end{array}$ & $x$ & $x$ & & & & & \\
\hline$\frac{\text { Iridoprocne }}{\text { bicolor }}$ & Tree swallow & & & & & & $x$ & \\
\hline$\frac{\text { cyanocitta }}{\text { cristata }}$ & Blue jay & & & & & & $x$ & \\
\hline$\frac{\text { cyanocitta }}{\text { stelleri }}$ & $\begin{array}{l}\text { Steller's } \\
\text { jay }\end{array}$ & & & $x$ & & & & \\
\hline$\frac{\text { Aphelocoma }}{\text { coerulescens }}$ & Scrub jay & & & $x$ & & & & \\
\hline Corvus corax & Common raven & & & $x$ & & & & \\
\hline$\frac{\text { Corvus }}{\text { brachyrhynchos }}$ & Common crow & & & $x$ & & & & \\
\hline$\frac{\text { Nucifraga }}{\text { columbiana }}$ & $\begin{array}{l}\text { Clark's } \\
\text { nutcracker }\end{array}$ & $x$ & $x$ & & & & & \\
\hline$\frac{\text { Gymnarninus }}{\text { cyanocephalus }}$ & Pinon jay & & & $x$ & & & & \\
\hline$\frac{\text { Parus }}{\text { atricapillus }}$ & $\begin{array}{l}\text { Black-c apped } \\
\text { chickadee }\end{array}$ & & & & & $\mathrm{x}$ & & \\
\hline Parus gambelTi & $\begin{array}{l}\text { Mount ain } \\
\text { chick adee }\end{array}$ & & & $x$ & & & & \\
\hline Parus inornatus & Plain titmouse & & & $x$ & & & & \\
\hline$\frac{\overline{\text { Psaltriparus }}}{\text { minimus }}$ & Common bushtit & & & & & $x$ & & \\
\hline
\end{tabular}


TABLE D-IV (cont)

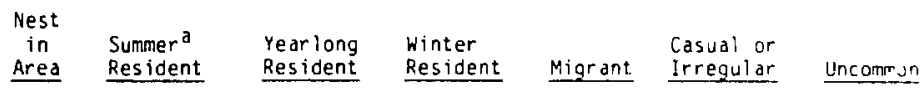

Passeriformes (cont)

sitta

carolinensis

Sitta

candensis

Certhia

familiaris

Sitta

pygmea

Cinclus mexicanus

Troglodytes

dedon

Catherpes

mexicanus

Salpinctes

obsoletus

Dumetelta

carolinensis

Toxostoma

rufum

Oreoscoptes

montanus

Turdus

migratorius

Hylocichla

gut tata

Hylocich

ustulata

Se iurus

noveboracens is

Sialia

mexicana

Sialia

currucoides

Myadestes

townsendi

Potioptila

caerulea

Regulus

satrapa

Regulus

calendula

Anthus

spinoletta

Bombycilla

garrulus

Bombycilla

cedrorum

Lanius

excubitor

Lañius

Iudovicianus
White-breasted

nuthatch

Red-breasted

nuthatch

Brown creeper

Pygmy nuthatch

Dipper

House wren

Canyon wren

Rock wren

Catbird

Brown

thrasher

Sage thrasher

Robin

Hermit

thrush

Swainson's

thrush

Northern

waterthrush

Western

b Tuebird

Mountain

b luebird

Townsend's

solitaire

Blue-gray

gnatratcher

Golden-crowned

$k$ inglet

Ruby-crowned

$k$ inglet

Water pipit

Bohemian

waxwing

Cedar

waxwing

Northern

shrike

Loggerhead

shrike $x$

$x$

$x$

$x$ 
TABLE D-IV (cont)

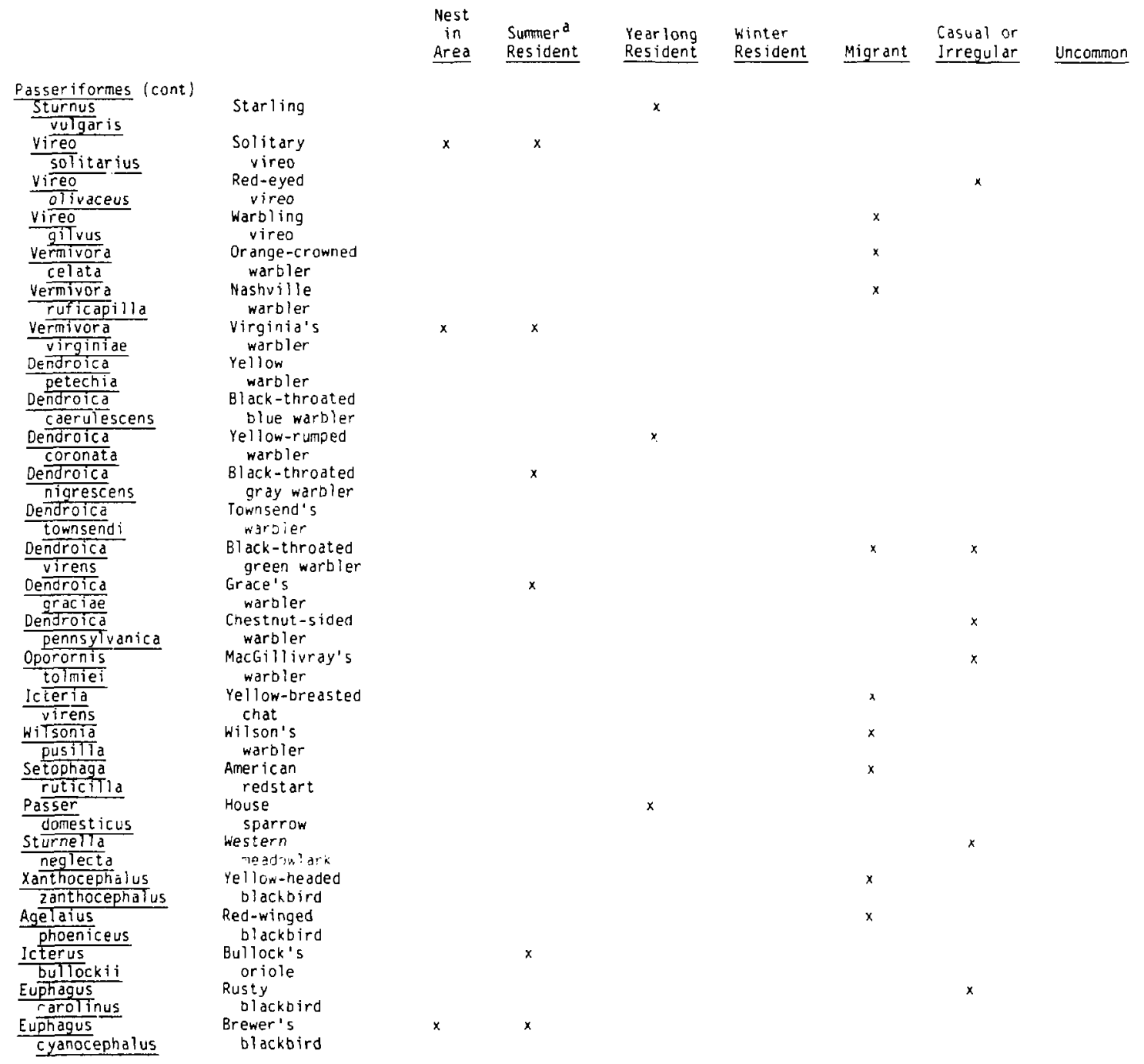


TABLE D-IV (cont)

$\begin{array}{clll}\begin{array}{c}\text { Nest } \\ \text { in } \\ \text { Area }\end{array} & \begin{array}{l}\text { Summer } \\ \text { Resident }\end{array} & \begin{array}{l}\text { Yearlong } \\ \text { Resident }\end{array} & \text { Winter } \\ \text { Resident } & \text { Migrant Lasualor } & \text { Irregular Incomenn }\end{array}$

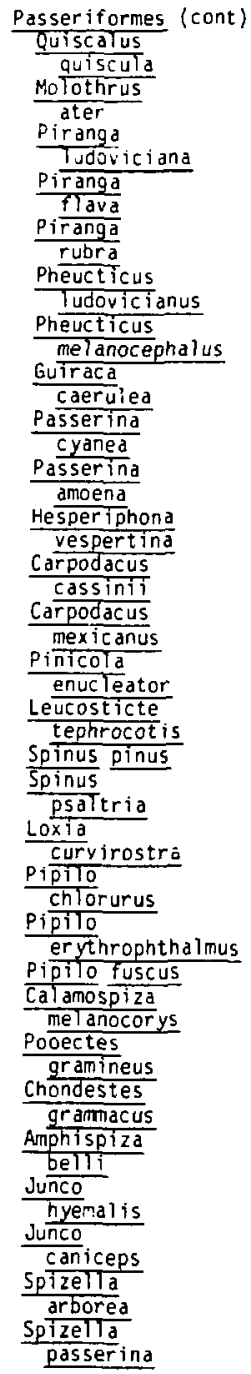

Common
grack le

Brown-headed

cowbird

Western

tanager

Hepatic

tanager

Rose-breasted

grosbeak

Black-headed

grosbeak

ilue

grosbeak

Indigo

bunting

Lazuli

bunting

Evening

grosbeak

Cassin's

finch

House

finch

Pine

grosbeak

Gray-crowned

rosy finch

Pine siskin

Lesser

Red

crossbill

Green-tailed

towhee

Rufous-sided

towhee

Brown townee

Lark

bunt ing

Vesper

sparrow

Lark

sparrow

Sage

sparrow

Dark-eyed

junco

Gray-headed

junco

Tree

sparrow

Chipping

sparrow

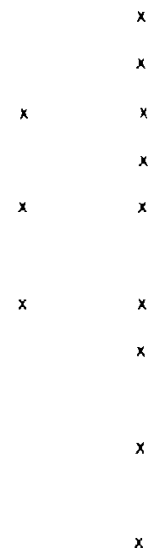

$x$

$x$

$x$

$x$

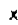

$x$

x

$x$ 
TABLE D-IV (cont)

\begin{tabular}{|c|c|c|c|c|c|c|c|c|}
\hline & & $\begin{array}{c}\text { Nest } \\
\text { in } \\
\text { Area } \\
\end{array}$ & $\begin{array}{l}\text { Summer } \\
\text { Resident } \\
\end{array}$ & $\begin{array}{l}\text { Yearlong } \\
\text { Resident } \\
\end{array}$ & $\begin{array}{l}\text { Winter } \\
\text { Resident } \\
\end{array}$ & Migrant & $\begin{array}{l}\text { Casual or } \\
\text { Irreguiar } \\
\end{array}$ & Uncommon \\
\hline \multicolumn{9}{|c|}{ Passeriformes (cont) } \\
\hline Spizella & Clay-colored & & & & & & & \\
\hline palioa & sparrow & & & & & & & \\
\hline SpizeTla & Brewer's & & & & & $x$ & & \\
\hline brewer $i$ & sparrow & & & & & & & \\
\hline Spizella & Fielo & & & & & & & \\
\hline pusiTa & sparrow & & & & & & & \\
\hline zonotrichia & Harris' & & & & $\mathrm{x}$ & & & \\
\hline querda & sparrow & & & & & & & \\
\hline zonotrichia & White-crowned & & & & & $x$ & & \\
\hline leucophrys & sparrow & & & & & & & \\
\hline zonotrichid & Golden-crowned & & & & & & & \\
\hline atricapitra & sparrow & & & & & & & \\
\hline Zonotrichid & white-throdted & & & & & & $\mathrm{x}$ & \\
\hline albicollis & sparrow & & & & & & & \\
\hline Passerella & Fox & & & & & & $x$ & \\
\hline iliaca & sparrow & & & & & & & \\
\hline MeTिकpiza & Lincoln's & & & & $x$ & & & \\
\hline Tincatrii & sparrow & & & & & & & \\
\hline Me $\longdiv { 0 s p i z a }$ & Swamp & & & & & & $x$ & \\
\hline georgiana & sparrow & & & & & & & \\
\hline "Ee & Song & & & $x$ & & & & \\
\hline melecia & sparron & & & & & & & \\
\hline
\end{tabular}


INVERTEBRATES

\begin{tabular}{|c|c|c|c|}
\hline Phylum & Class & Order & $\begin{array}{l}\text { Estimated } \\
\text { No. Species }\end{array}$ \\
\hline Annelida & $\frac{01 \text { igochaeta }}{\text { (segmented worms) }}$ & & 1 \\
\hline Nematomorpha & $\frac{\text { Gordi aceae }}{\text { (round worms) }}$ & & 2 \\
\hline \multirow[t]{23}{*}{ Arthropoda } & $\frac{\text { Chilopoda }}{\text { (centipedes) }}$ & & 5 \\
\hline & $\frac{\text { Diplopoda }}{\text { (milipedes) }}$ & & 1 \\
\hline & Arachnida & $\frac{\text { Acarina }}{\text { (ticks and mites) }}$ & $>80$ \\
\hline & & $\frac{\text { Solpugida }}{\text { (sun "scorpions") }}$ & 1 \\
\hline & & & 1 \\
\hline & & & 1 \\
\hline & & $\begin{array}{l}\text { Ar aneida (spiders) } \\
\text { (16 families) }\end{array}$ & $74-100$ \\
\hline & Insects & Thysanura & 1 \\
\hline & & Collembola & $32-37$ \\
\hline & & Orthoptera & $4-6$ \\
\hline & & $\frac{\text { Psocoptera }}{\text { Thysanoptera }}$ & $\begin{array}{l}3-4 \\
4-6\end{array}$ \\
\hline & & Hemiptera & $28-33$ \\
\hline & & Homoptera & $18-23$ \\
\hline & & $\frac{\text { Coleoptera }}{\text { Mecoptera }}$ & $\begin{array}{c}46-51 \\
1\end{array}$ \\
\hline & & Neuroptera & $3-5$ \\
\hline & & Rhaphidioidea & 1 \\
\hline & & Trichoptera & $a_{0}^{1}$ \\
\hline & & $\frac{\text { Leoraoptera }}{\text { Diptera }}$ & $\begin{array}{r}9-12 \\
50-57\end{array}$ \\
\hline & & Siphonaptera & $2-3$ \\
\hline & & $\frac{\text { Hymenoptera }}{\text { (Formicidae }} 22-25$ ) & $54-65$ \\
\hline & & Protura & 1 \\
\hline & & Diplura & 3 \\
\hline & & Total No. Species & $430-535$ \\
\hline
\end{tabular}

